Universidade de São Paulo

Faculdade de Filosofia, Letras e Ciências Humanas

Departamento de Letras Orientais

Programa de Pós-Graduação em Estudos Judaicos e Árabes

\title{
Trajetórias migratórias e construções identitárias de palestinos em Santa Catarina
}

\section{Gabriel Mathias Soares}

Dissertação apresentada como requisito para aquisição do título de mestre pelo Curso de Pós-Graduação em Estudos Judaicos e Árabes, Departamento de Letras Orientais, Faculdade de Filosofia, Letras e Ciências Humanas, Universidade de São Paulo.

Orientador: Prof. Dr. Paulo Daniel Farah 

Em memória de minha tia Neusa Helena Soares e de meu tio Saulo Soares. 


\section{Agradecimentos}

Há inúmeras pessoas que gostaria agradecer pela importância que tiveram para meu mestrado. A todos eles eu ofereço meu profundo agradecimento.

Primeiramente, aos meus pais, Jauro e Mariza, que sempre deram grande apoio e incentivo fundamental em minha busca pela realização de meus sonhos, além de compreensão.

Às minhas tias, Zeula e Maura, que sempre me acolheram em Florianópolis quando precisei ir para lá em decorrência de minha pesquisa e que sempre estarão no meu coração.

Aos meus outros familiares que moravam perto, como minha irmã, Elisa, com que habitei nos primeiros anos em São Paulo, e os que moram longe, em especial minha avó, Elizabeth, meu tio Ney e minha tia Celminha, cujo apoio e estímulo foram essenciais.

Aos amigos de meus pais, Evilásio e Rita, que me hospedaram em Tubarão para que eu realizasse pesquisas na região sul do Estado.

A meu amigo e de meu pai, Marcos May Philippi, que me hospedou nos seis primeiros meses em São Paulo, num momento que foi essencial para minha inserção e adaptação à nova cidade.

Em especial, ao professor Paulo Daniel Elias Farah, que foi muito mais que um orientador, pois pude constituir com ele verdadeiros laços de amizade e confiança, que foram essenciais para meu desenvolvimento como pesquisador. Por isso, também agradeço a professora Patrícia Santos por ter me introduzido a ele.

Ao professor João Klug que teve uma influência decisiva para minha opção pelo tema da imigração e que me orientou não somente durante a graduação, como depois.

Aos colegas e amigos do antigo LABIMI, atual LABIMHA, que por fazer parte de minha formação passada, terão sempre meus agradecimentos.

Ao Prof. Manhal que, além de ser meu primeiro professor de árabe, me apresentou aos membros da comunidade palestina de Florianópolis, de onde parti para buscar outros colaboradores no Estado. Este trabalho não seria possível sem ele.

A todos os colaboradores que me cederam entrevistadas, sem as quais este trabalho não existiria. Em especial, a um deles que não está vive mais e cuja entrevista não foi incorporada diretamente no trabalho, mas serviu para reflexão do tema estudado: 
Ahmad Yassir Mustafa. Todos os outros nomes, igualmente dignos de menção, estão listados ao final do trabalho.

A meus colegas do Grupo de Trabalho Oriente Médio e Mundo Muçulmano, com os quais foram realizadas discussões que permitiram apurar o senso crítico em relação ao tema estudado.

A meus colegas e amigos do Grupo de Estudo Edward Said e Crítica ao Orientalismo que enriqueceram meu trabalho com debates e diversas contribuições.

A todos outros amigos e colegas de minha antiga graduação (História) com quem mantive contato e, sobretudo, aos de pós-graduação com quem convivi e compartilhei tanto. 


\section{Sumário}

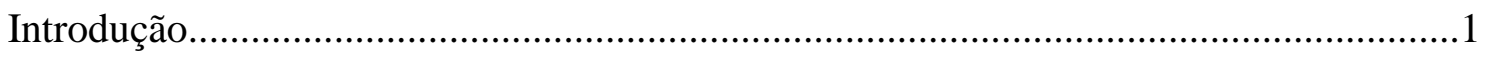

1. Palestinos no contexto da imigração árabe para o Brasil..........................................11

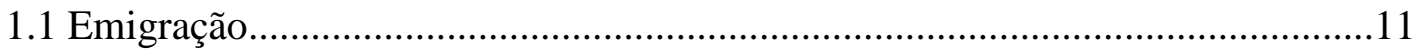

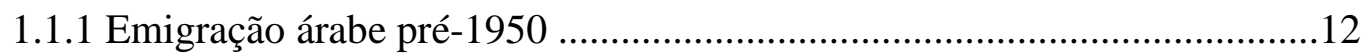

1.1.2 Emigração árabe pós-1950..................................................................... 18

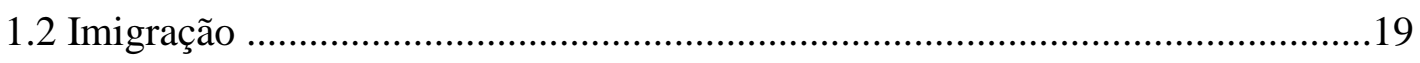

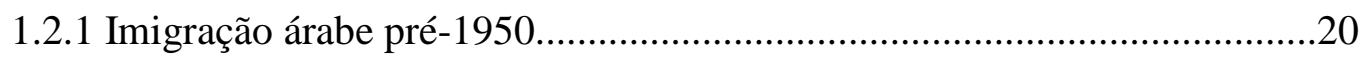

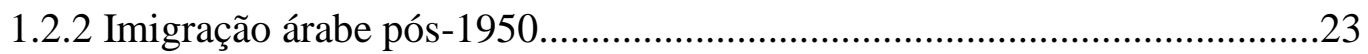

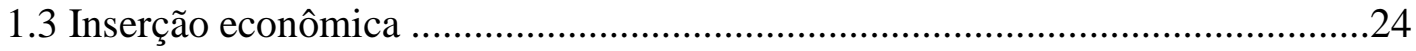

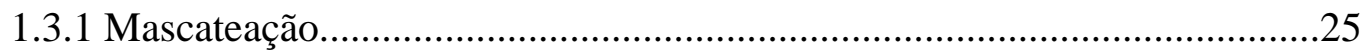

1.3.2 Ascenção socioeconômica do grupo sírio-libanês....................................27

1.3.3 Trajetória econômica de imigrantes árabes pós-1950 ................................29

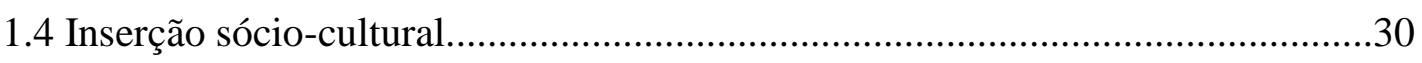

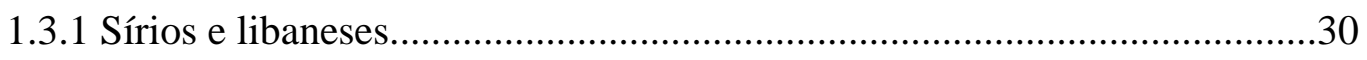

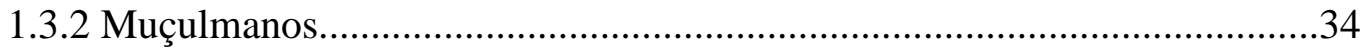

2. Entre a Palestina e o Brasil: a trajetória migratória dos palestinos de Santa Catarina37

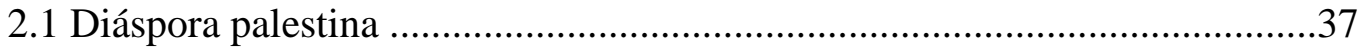

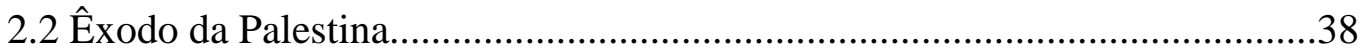

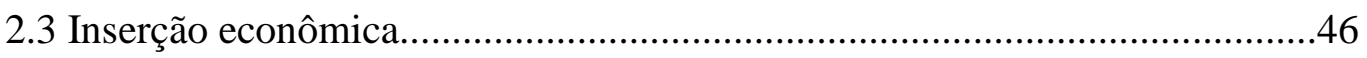

2.4 Inserção no meio sociocultural brasileiro .................................................52

2.5 Circulação migratória..............................................................................55

3. Identidades de uma diáspora: ser palestino e brasileiro em Santa Catarina............... 60

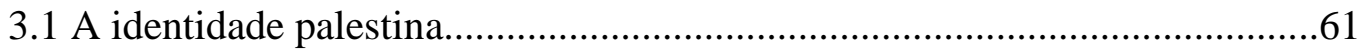

3.2 O Brasil para seus imigrantes palestinos...................................................69

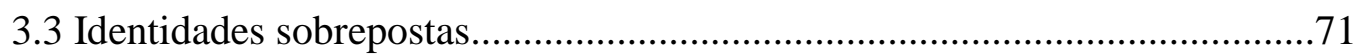

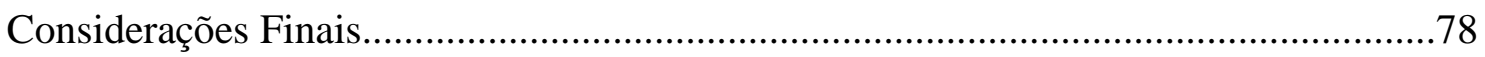

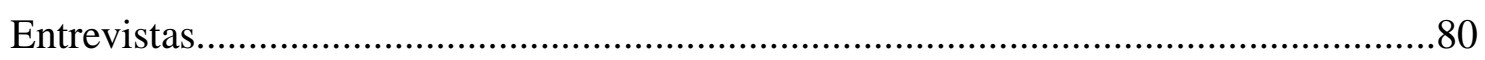

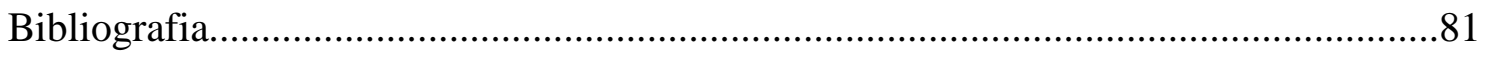

Anexo Mapa da Imigração Palestina para Santa Catarina ............................................82 


\section{Resumo}

A trajetória dos imigrantes palestinos em Santa Catarina esteve marcada por redes sociais de solidariedade étnica e familiar. Dessa forma, em todo seu percurso, as questões identitárias estiveram fortemente presentes nessa imigração caracteristicamente autônoma, sem qualquer auxílio estatal, e urbana. Os vínculos familiares, étnicos e religiosos, forneceram os alicerces para inserção econômica e social, assim como para comunidades locais e associações entre imigrantes. Intimamente associada a este processo, a Questão Palestina se fez presente durante toda trajetória desses palestinos tanto como indivíduos, como parte de uma coletividade ligada a essa questão. Fortemente marcada na memória individual e coletiva, está a expropriação e/ou a ocupação da terra habitada por eles e/ou por seus familiares mais próximos, que os afeta de diversas maneiras (social, cultural, politica e economicamente), particularmente no que se refere às causas da emigração. Associável sempre a todos, entretanto, está o pertencimento a uma coletividade cuja identidade está em questão em muitos lugares do mundo. A busca pela emancipação de seu torrão natal torna-se assim um dos elementos fundamentais de sua identidade, que por sua vez se torna uma ferramenta indispensável para manutenção do direito de retorno daqueles que foram expulsos e de seus descendentes, como também contra a expulsão daqueles que lá permanecem. A inserção numa cultura diferente, bem como em outra realidade sociopolítica, trouxe mudanças e dilemas em relação aos hábitos e a própria autodefinição. Diante dessa realidade, a etnicidade foi mantida através do vínculo com a causa palestina, a família, a religião e a comunidade de imigrantes. Entretanto, o apego aos costumes e as tradições entre os palestinos em Santa Catarina não os fez menos brasileiros em sua visão, pois ao mesmo tempo incorporaram a nacionalidade brasileira a sua própria maneira.

Palavras-chaves: Palestina, migração, diáspora, identidade, redes sociais, memória. 


\begin{abstract}
The trajectory of Palestinian immigrants in Santa Catarina was marked by social networks of family and ethnic solidarity. Thus, throughout its path, the identity issues were strongly present in this characteristically autonomous, without any state aid, and urban immigration. Family ties, ethnic and religious, have provided the foundation for economic and social inclusion, as well as local communities and associations among immigrants. Closely associated with this process, the Palestine Question was present during the entire trajectory of these Palestinians as individuals, as part of a community linked to this issue. Strongly marked in individual and collective memory, is the expropriation and / or occupation of land where they and / or their close family members inhabit, which affects them in a variety of ways (socially, culturally, politically and economically), particularly in respect of the causes of emigration. Associable always to everyone, however, is belonging to a community whose identity is in question in many places around the world. The search for the emancipation of their homeland have thus becomes a fundamental element of their identity, which in turn becomes an indispensable tool for maintaining the right of return of those who were expelled and their descendants, as well as those who remain there resisting their expulsion. The setting in a different culture, as well as other socio-political reality, brought changes and dilemmas in relation to habits and their own self-definition. Having this reality in mind, ethnicity was maintained through ties with the Palestinian cause, family, religion and immigrant community. However, attachment to the customs and traditions among Palestinians in Santa Catarina did not make them less Brazilians in their view, because at the same time they incorporated Brazilian nationality in their own way.
\end{abstract}

Keywords: Palestine, migration, diaspora, identity, social networks, memory. 


\section{Introdução}

Desde o instante em que surgiu há mais de 60 anos atrás, a Questão Palestina tem chamado a atenção de diversas pessoas e organizações pelo mundo, influindo e sendo influenciada decisivamente em eventos que extrapolam os limites do exíguo território estabelecido pelos britânicos para seu Mandato da Palestina. Após a criação do Estado de Israel, a maioria do povo palestino foi desterrada de mais de dois terços de seu território original, restando nessa porção apenas uma fração da população original palestina, principalmente na região da Galiléia. O restante da população se dividiu entre refugiados e os habitantes dos territórios tomados da Palestina histórica pelo Egito e pela Jordânia até a ocupação por Israel em 1967. Influenciados diretamente ou indiretamente pela situação conflituosa na região, muitos emigraram para os países mais próximos no Oriente Médio ou mesmo para outros continentes como a América do Sul.

A presença palestina no Brasil é difícil de ser datada ou quantificada (Jardim, 2006). Não há muitos dados oficiais, ao que se acrescenta uma característica marcante dessa migração, a mobilidade. As principais fontes de informação são os relatos orais dos próprios palestinos e os documentos que carregam de sua intricada trajetória. Isto se deve em parte à própria complexidade do tema da identidade palestina, dificilmente expresso nos diversos documentos que podem carregar de nacionalidades variadas. Esses aparecem em alguns censos oficiais do Brasil registrados principalmente como jordanianos, com um número ínfimo de registrados como palestinos. Sem dúvida, nenhuma estatística irá computar toda complexidade das definições que foram atribuídas a esse povo do decorrer do século $\mathrm{XX}$ conforme sua terra natal passou da dominação otomana para o mandato britânico, para a anexação à Jordânia, para ocupação israelense e finalmente para Autoridade Nacional Palestina, criada em 1994.

No Brasil, conforme a atribuição dada aos sírio-libaneses vindos com documentos do Império Otomano para este país no final do século XIX e na primeira metade do século XX e aplicada aos imigrantes árabes de forma geral e seus descendentes, os palestinos recebem popularmente a denominação de "turcos". Já a designação de árabe traz consigo uma carga semântica muito importante para a união das diversas populações de língua árabe, dentro e fora dos países árabes. No entanto, essa dificilmente substitui a importância central daquilo

\footnotetext{
${ }^{1}$ De modo geral, notam-se duas grandes correntes migratórias árabes para o Brasil, uma anterior a Segunda Guerra Mundial, composta sobretudo por sírios e libaneses cristãos (católicos e ortodoxos), e uma posterior a essa guerra, composta majoritariamente por muçulmanos, tanto por sírios e libaneses, quanto por palestinos e algumas outras nacionalidades árabes.
} 
que é expresso em termos de forte valor significativo, como país (bilád) ou pátria (watan), apesar dos esforços de alguns nacionalistas árabes. No caso dos palestinos, a busca pela emancipação de seu torrão natal é um dos elementos fundamentais de sua identidade, que por sua vez se torna uma ferramenta indispensável para manutenção do direito de retorno daqueles que foram expulsos e também contra a expulsão daqueles que lá permanecem.

Os palestinos em Santa Catarina constituem um grupo pequeno em termos de proporção, disperso e numericamente diminuto em relação a uma população estimada em 2010 em mais de seis milhões ${ }^{2}$. Apesar de não existir um registro oficial sobre o número de residentes neste Estado que nasceram no território da Palestina ${ }^{3}$, é possível avaliar em aproximadamente 200 famílias $^{4}$ (nucleares) através de contatos pessoais ou através das associações em nível estadual, como o Comitê Catarinense de Solidariedade ao Povo Palestino, e federal, como a Federação Palestina. A maioria se localiza, em escala decrescente, em Florianópolis, Criciúma, Tubarão e Lages (A Notícia, 14/10/2000). No entanto, o propósito de estudar especificamente este grupo árabe não tem relação com o impacto numérico que exercem na formação da sociedade brasileira ou catarinense, mas sim seu significado e importância para compreensão de diversas questões como a manifestação e a conservação da identidade no afastamento do solo natal que caracteriza essa diáspora. Também evidenciam o intricado processo de negociação da identidade nacional por grupos minoritários que contestam a narrativa nacional uníssona e monolítica, limitada às fronteiras do Estado (EDER, 2003).

Conforme um paradigma tradicional de percepção das identidades, essas consistem numa forma de pertencimento particular e exclusiva, que se estabelece por oposição a outra entidade da qual não se faz parte e com a qual não se compartilha nada de essencial. Daí surge uma dicotomia entre "nós" e os "outros", freqüentemente usada de forma depreciativa, principalmente quando se trata de povos considerados genericamente subdesenvolvidos ou

\footnotetext{
${ }^{2}$ A população recenseada e estimada de Santa Catarina em 2010 foi de 6.248 .436 no último censo do IBGE de 2010: http://www.ibge.gov.br/home/estatistica/populacao/censo2010/tabelas_pdf/Santa_catarina.pdf acesso em 01/10/2012.

${ }^{3}$ Aqui definido como na Carta Nacional Palestina de julho de 1968, ou seja, conforme as fronteiras do Mandato britânico da Palestina. (LAQUER \& RUBIN, 2001: 117)

${ }^{4}$ Khader Othman, uma liderança da comunidade palestina de Santa Catarina, informou que: "Entre Joinville a Araranguá, tem umas 200 famílias, mais ou menos." Em Florianópolis Claudia Voigt Espinola registra cerca de 60 famílias nucleares árabes muçulmanas, sem distinção entre palestinos e libaneses, que contrasta com dados oficiais (embora não indique precisamente a fonte, nem a data): “A Polícia Federal, no entanto, registra em Florianópolis quarenta e três libaneses, quarenta e seis jordanianos e seis palestinos, sem distinção entre cristãos ou muçulmanos. Tratando-se de um grupo de imigrantes, nem todos estão com sua entrada no país legalizada, por isso os números da Polícia são exíguos, bem como há os que optam por legalizar sua situação optando pela naturalização." (ESPINOLA, 2005: 6). Munif Mahmoud Salim Omar informa que em Criciúma, cidade com a segunda maior concentração, estima-se que haja até 15 famílias palestinas.
} 
atrasados. Aponta-se nessas sociedades e culturas a ausência de direitos humanos, de igualdade entre homens e mulheres, como se fossem normas perfeitamente instituídas e convencionadas em todas as "nossas" sociedades, sem refletir o que realmente significam e como ainda estão sendo desenvolvidas e interpretadas de diversas maneiras por diversos grupos, religiões e nações. A base dessa dicotomia é, antes de tudo, a oposição natural e incompatível daquilo que somos e do que os outros, definida na atualidade sobretudo em termos culturais (embora seja possível dizer que ecoe vestígios de uma mentalidade racista, quando não o é declaradamente).

Essa impermeabilidade cultural é presente na obra de Samuel P. Huntington, $O$ Choque de Civilizações, assim como na percepção de muitos fundamentalistas cristãos ou muçulmanos. Nessa obra direcionada especialmente a estadistas ocidentais, Huntington elabora um esquema de interpretação da política mundial baseado nas afinidades culturais entre diversos países e nas freqüentes associações transnacionais estabelecidas com o objetivo comum de derrubar as barreiras alfandegárias. $\mathrm{O}$ alicerce e o limite dessas afiliações estariam no pertencimento a uma mesma civilização específica, ou seja, à ocidental, à islâmica, à ortodoxa, à latino-americana, à chinesa, à japonesa ou, quiçá, a uma africana (possivelmente elegível ao status de "civilização"). Esse autor entende civilização como "o mais alto agrupamento cultural de pessoas e o mais amplo nível de identidade cultural que as pessoas têm aquém daquilo que distingue os seres humanos das demais espécies", como "o maior "nós" dentro do qual nos sentimos culturalmente à vontade, em contraste com todos os outros "ele" por aí afora" (Huntington, 1997: 48) e que "os alinhamentos definidos pela ideologia e pelos relacionamentos de superpotência estão dando lugar aos alinhamentos definidos pela cultura e pela civilização" (Ibidem: 153). Isto significa que as civilizações constituirão entidades exclusivistas e conflitantes, em que "as relações intercivilizacionais que surgirão normalmente variarão entre distanciadas a violentas" e "a confiança e a amizade serão raras" (Ibidem: 159-160).

Contrastando com esse quadro rígido e inconciliável de entidades culturais estão as visões de Edward W. Said e Stuart Hall. Cada um a sua maneira contrapõe essa posição purista frente à cultura. De certa forma, ambos percebem as diversas culturas como híbridas e mestiçáveis, vendo como um tanto ilusória a mesmice e "autenticidade" separatista ou exclusiva. Como definiu Said: "longe de serem algo unitário, monolítico ou autônomo, as culturas, na verdade, mais adotam elementos "estrangeiros", alteridades e diferenças do que os excluem conscientemente" (Said, 1995: 46). A ênfase aí está na interdependência das culturas, mesmo quando se busca formas de diferenciação e segregação dos "outros", que 
muitas vezes acabam por fazer desse um componente principal e quase indispensável para delimitar e definir seu "oposto", ou seja, o "nós".

Segundo Hall "a cultura é uma produção" e "não é uma questão do que as tradições fazem de nós, mas daquilo que nós fazemos das nossas tradições". Portanto, "a cultura não é uma questão de ontologia, de ser, mas de se tornar" (Hall, 2003: 43). Isto significa que as identidades culturais são posições adotadas em conformidade com as inúmeras circunstâncias que formam a trama das tendências e conjunturas históricas, ao invés de uma essência fixada em todo ser humano no momento em que nasceu. Contraditoriamente, é essa essência que muitas vezes se busca na definição de uma identidade, como um liame indelével entre o individuo e sua sociedade. As transformações sociais, políticas ou culturais condicionam a relação de importância com os significados dos diversos elementos que constituem a vida humana em sociedade, como a religião, a etnia, a posição social, em que grupos e indivíduos buscam conforto e direcionamento. Podemos assim entender como as informações destacadas nos meios de comunicação sobre o que entendemos por "outro" partem muitas vezes dos nossos próprios interesses e do que pensamos de nós mesmos, mais do que um anseio desinteressado por uma verdade objetiva.

Especialmente no que se refere aos temas Mundo Muçulmano, Oriente Médio e/ou Mundo Árabe, historicamente foi constituído um paradigma de análise que tende a realçar os aspectos exóticos, a diferença, quando não o fanatismo, a irracionalidade e a sensualidade, aspectos opostos a percepção que tinham de si mesmo e de sua cultura os estudiosos europeus dessa região no século XIX. Hoje, essa ótica é difundida através dos diversos veículos de comunicação, como jornais, livros, televisão, rádio e também sites na internet, que por vezes trazem uma visão ainda mais depreciativa e caricaturada desses povos direcionada aos desinformados neste assunto, principalmente no "Ocidente" (nesse caso incluindo o Brasil). O Orientalismo que Said definiu como uma perspectiva eurocêntrica e aliada a interesses imperiais ainda permanece vivo, mas com novas roupagens, como ele mesmo percebia no momento em que se encerrava a era colonial:

Um aspecto do mundo eletrônico é que houve um reforço dos estereótipos pelos quais o Oriente é visto. A televisão, os filmes e todos os recursos da mídia têm forçado as informações a se ajustar em moldes cada vez mais padronizados. No que diz respeito ao Oriente, a padronização e os estereótipos culturais intensificaram o domínio da demonologia imaginativa e acadêmica do "misterioso Oriente" do século XIX. Em nenhum lugar isso é mais verdade do que na forma como o Oriente Próximo é compreendido. Três coisas contribuíram para transformar até a mais simples percepção dos árabes e do islã numa questão altamente politizada, quase estridente: primeiro, a história do preconceito popular contra os árabes e o islã no Ocidente, que se reflete diretamente na história do Orientalismo; segundo, a luta entre os árabes e o sionismo israelense, e seus efeitos sobre os judeus americanos, bem como sobre a cultural liberal e a população em geral; terceiro, a quase total 
ausência de qualquer posição cultural que possibilite a identificação com os árabes e o islã ou um discussão imparcial a seu respeito. Além do mais, não é preciso dizer que, como o Oriente Médio é agora identificado com a política da Grande Potência, a economia do petróleo e a dicotomia simplista entre um Israel democrático e amante da liberdade e os árabes malvados, totalitários e terroristas, as chances de uma visão clara do que dizemos ao falar sobre o Oriente Próximo são deprimentemente pequenas. (Said, 2007: 58)

Entretanto, enquanto essa imagem monolítica é construída, as telecomunicações e a divisão de trabalho internacional estão mudando o mundo muçulmano de modo jamais precedido. Contatos anteriores não tiveram tanto impacto na esfera privada. Agora, a globalização integrou regiões distantes de tal forma que mesmo partes remotas do mundo se vêem pertencendo a uma única comunidade global. Esta chamada 'supercultura', que é vista por muitos no mundo como desejável, tem por base aspirações de consumo em comum, tanto de bens materiais quanto simbólicos (Weiss, 1994). Do mesmo modo, a globalização tem incentivado muito a disposição para mobilidade, em grande medida através da internacionalização do mercado de trabalho, que tem resultado numa enorme quantidade de pessoas a movimentar-se pelo mundo em função de oportunidades e promessas ligadas a essa reestruturação do capitalismo global. Localizados nas mais diferentes regiões do mundo, tanto em termos geográficos, como de desenvolvimento econômico, os muçulmanos acabam representando uma grande proporção dessa movimentação mundial, de modo que comunidades muçulmanas se tornaram parte de muitos países ocidentais (Ahmed \& Donnan, 1994).

O fenômeno contemporâneo das circulações migratórias está inserido nas transformações tecnológicas, sociais e econômicas da "Era da Informação" atual. A migração já não é mais pensada exclusivamente dentro da dicotomia emigração e imigração, onde se pressupõe um rompimento do migrante com sua terra de origem e sua inserção na nova sociedade. Os espaços de fluxos hoje quebram a coesão entre tempo e espaço nas relações sociais, permitindo uma "multilocalidade" dessas relações através dos novos meios de comunicação em escala global, como a internet. O migrante contemporâneo dessa forma não se vê distanciado completamente do local de origem ou de outros locais pelos quais passou, na medida em que ele pode conectar-se com eles através das redes de comunicação, sobrepondo diversos espaços sociais ao universo de relações localizadas, ao Hic et Nunc.

Em sua totalidade, a experiência da migração está sendo transformada em todos seus aspectos pela disseminação e democratização das mais recentes tecnologias de comunicação e transporte, viabilizando novos percursos e itinerários nas rotas migratórias, assim como a permanência ou a renovação constante da situação de migrante. A globalização em si tem 
alterado o universo em que as dinâmicas migratórias se inserem, interconectando organizações, instituições e economias inteiras, flexibilizando fronteiras territoriais. Essa nova organização da sociedade em torno das redes traz um corolário fundamental demonstrado por Castells (1999: 565), em que "A presença na rede ou a ausência dela e a dinâmica de cada rede em relação às outras são fontes cruciais de dominação e transformação da nossa sociedade: uma sociedade que, portanto, podemos apropriadamente chamar de sociedade em rede, caracterizada pela primazia da morfologia social sobre a ação social”.

Tendo em consideração o poder das redes sobre as relações sociais, esse trabalho focaliza um grupo de migrantes específicos num espaço específico, os palestinos em Santa Catarina, que teve sua trajetória marcada pela força das redes sociais e também por transformações alicerçadas nas mudanças do meio tecnológico-informacional. Assim, de uma clássica migração como fenômeno de ruptura e desligamento (Sayad, 1998), para uma transmigração (ou circulação migratória), um processo no qual o imigrante mantém relações multifacetadas entre seu país e o de origem, forjando vínculos entre ambos (Schiller, Basch \& Blan, 1995: 48).

De acordo com essa avaliação, os "transmigrantes" são imigrantes que mesmo assentados e incorporados a outra sociedade (em termos econômicos, políticos, etc.), permanecem com vínculos com seus países de origem, inclusive participando da realidade social, econômica e política desse e pertencendo simultaneamente a mais de um estado-nação. Vivem continuamente a realidade do país de residência, ao mesmo tempo mantendo ligações, construindo instituições, conduzindo transações e influenciando acontecimentos nacionais e internacionais do país de emigração.

O grupo selecionado para é de palestinos, homens, de primeira geração. No entanto, eles não vieram no mesmo período e nem do mesmo modo. As distintas trajetórias traçam um perfil heterogêneo da imagem tradicional do imigrante árabe como um jovem aventureiro. A imigração de mulheres palestinas caracterizasse via de regra como uma de acompanhamento de parentes, esse fenômeno distinto e requer um estudo a parte, o que não está no escopo desse trabalho. O mesmo vale para as gerações seguintes e seus descendentes, cuja investigação também toma um viés diferente.

O foco de análise dessa pesquisa centra-se também na manifestação e na conservação da identidade no afastamento do solo natal que caracteriza a imigração palestina. De certa forma, a identidade palestina jaz entre o exílio e o nacionalismo, que Said concebe como “opostos que informam e constituem um ao outro". Neste caso, "o nacionalismo é uma declaração de pertencer a um lugar, um povo, a uma herança cultural" enquanto "o exílio é 
uma solidão vivida fora do grupo: a privação sentida por não estar com os outros na habitação comunal" (Said, 2003: 49-50). Em ambos há uma referência ao lugar, sendo que o primeiro refere-se ao pertencimento grupal e o segundo refere-se ao banimento anômico e individual. Pode-se dizer que a situação dos imigrantes palestinos envolve um meio termo das duas definições, uma privação experienciada em grupo, principalmente familiar.

De modo caracteristicamente pós-moderno, mas diferentemente da experiência nacional de tantos outros lugares no mundo, as identidades culturais no Brasil podem manifestar abertamente, e sem aparente contradição, um caráter ambivalente ${ }^{5}$. Ao invés de uma definição hifenizada usada em países como os Estados Unidos da América, em que se forma um grupo próprio para uma identificação com dois grupos diferente que não é totalmente um nem o outro, assume-se uma identidade dupla e não-hifenizada.

Assim, o pertencimento simultâneo a duas nacionalidades, como a palestina e a brasileira, se mostra possível, sem implicar qualquer contradição para estes. Não se é menos brasileiro porque se é palestino, nem deixa-se de ser menos palestino porque se é brasileiro. É uma miscigenação cultural que não produz um novo elemento híbrido, mas que incorpora ao mesmo tempo dois "nós" distintos a uma mesma pessoa. Não significa uma hierarquia de identidades menores e maiores, como ser árabe em geral e ser palestino em específico, mas uma dupla vivência duas dimensões do seu "eu", separadas ou conciliadas, mas não excludentes. Esse ideal, no entanto, não deixa de apresentar contradições, especialmente quando no que se refere à hábitos culturais.

A metodologia de pesquisa utilizada nesta dissertação para estudar esse grupo, cuja trajetória e visão de mundo é transparente para a documentação oficial, para foi a da História Oral $^{6}$. Para analisar os percursos e as negociações identitárias desse grupo em Santa Catarina foram utilizadas, como fontes nucleares, entrevistas com imigrantes palestinos domiciliados em Florianópolis, Tubarão, Criciúma, Lages e Balneário Camboriú Foi optado aqui pelo método da transcriação, definida por Meihy como "a entrevista trabalhada já em sua fase de apresentação pública” (Meihy, 2005: 262).

\footnotetext{
${ }^{5}$ Como concluiu Espinola em sua tese de doutorado: "Trazendo para este contexto, a comunidade árabe em seu diálogo intercultural, dentro do contexto local e nacional, com sua história da incorporação de imigrantes e da construção da nação brasileira, mantém a possibilidade de sentir-se palestino e brasileiro, sem o hífen (comum em tantas outras nações, como os EUA). Passado o período de nacionalização intensiva e avançando num processo de "revival cultural", as populações que reivindicam sua etnia podem seguir abraçando duas ou mais". (ESPINOLA, 2005: 227).

${ }^{6}$ Como coloca Meihy, embora a história oral possa ser vista como um modo de se obter informações onde não há outras fontes, seu uso de forma alguma se esgota aí, pois, como modernamente tem se dado valor explicativo central à experiência e à subjetividade. A história oral surge como um dos modos de captá-las, especialmente daqueles que jamais a registraram ou a registrariam (Meihy, 2005: 55). A História Oral além de permitir uma mudança de enfoque, possibilita a abertura de novas áreas de investigação (Thompson, 1998: 27)
} 
As informações serão baseadas nas palavras e nas memórias dos entrevistados, quando tratam de si mesmo no presente e no passado. No entanto, a oralidade capta elementos do presente quando se refere ao passado, da mesma forma que usa o passado para falar do presente e requer um cuidado diferente daquele aplicado aos textos escritos. Ela está sujeita a subjetividade da memória, que esquece, confunde, esconde e altera as lembranças e as informações de tempos diferentes, do individual e do coletivo. A memória captada pelas fontes orais tem suas próprias especificidades como documento histórico e, utilizando-se das palavras de Le Goff para defini-la:

Fenômeno individual e psicológico... , a memória liga-se também à vida social... Esta varia em função da presença ou ausência da escrita... e é objeto de atenção do Estado, que para conservar os traços de qualquer acontecimento do passado..., produz diversos tipos de documento/monumentos, faz escrever a história... , acumular objetos... A apreensão da memória depende deste modo do ambiente social... e político... trata-se da aquisição de regras de retórica e também da posse de imagens e textos... que falam do passado, em suma, de um certo modo de apropriação do tempo... (Legoff, 2003: 419)

Quando se buscam dados através da história oral, é necessário compará-los a outras fontes, com critérios estabelecidos para busca, para averiguação dessas informações. A menção por entrevistados de datas, lugares ou números diferentes daqueles conhecidos ou prováveis, pode significar uma falha da memória, a irrelevância da informação para mesmo e/ou um equívoco ou uma "mentira". É preciso lembrar que para história oral não existe mentira no sentido moral, pois toda mentira decorre de intenções que merecem compreensão (Meihy, 2005: 54).

Foram realizadas para essa pesquisa oito entrevistas com palestinos residentes em Santa Catarina. Três entrevistas foram realizadas em Florianópolis no segundo semestre de 2007 e as outras no segundo semestre de 2010 em cinco outras cidades do Estado. Todos os entrevistados são imigrantes homens de primeira geração e representam a maior parte da mesma, pois casamentos entre homens palestinos e mulheres brasileiras (não-palestinas) foram preponderantes entre as primeiras levas de imigrantes.

O perfil dos imigrantes de primeira geração tão pouco é homogêneo, representando diferenças geracionais importantes. Três desses imigrantes podem ser considerados "típicos pioneiros", pois chegaram ainda nos primeiros anos da imigração palestina para o Brasil e mais particularmente para o Estado (década de 1950). Mesmo entre esses, no entanto, 
descobrem-se redes e contatos que o antecederam ou serviram de apoio, mesmo que não fosse constituída por parentes ou conterrâneos. Uma espécie de pioneiro "atípico" pode ser considerado o palestino residente em Lages, que além de ser originário de um local incomum nessa imigração para o Brasil (Gaza), também foi expulso de lá e chegou nesse país sem qualquer contato.

A segunda leva de imigrantes deixou sua terra natal antes da ocupação da Cisjordânia e da Faixa de Gaza por Israel em 1967, mas já possuíam algum parente próximo residindo no Brasil, o que ocasionou um tipo distinto de inserção para esses. Esses já não passaram pela “modelar" experiência de mascatear, como seus parentes e conterrâneos mais próximos antes deles. Aqueles que vieram após 1967, mesmo os que vieram já adultos, encontraram também de forma geral um parente próximo ou um amigo que lhes prestou auxílio. Nessa leva, há muitos filhos que vieram ao encontro de seus pais há muito distantes para viver no Brasil e escapar as agruras de um regime de ocupação.

Além das entrevistas, foram empregadas como fontes também matérias em jornais publicadas sobre ou por membros dessa comunidade, como também para compreensão do fenômeno mais amplo da diáspora palestina, por sua vez ligada a Questão Palestina. Assim, uma série de documentos e dados oficiais digitalizados e acessíveis na internet referentes à Palestina serviram de material de apoio. No entanto, eles têm de modo geral uma finalidade mais secundária que primária nesta pesquisa, pois melhoram e esclarecem a compreensão do tema com um todo, mas não constituem diretamente informações do objeto de estudo específico a ser investigado e analisado.

No primeiro capítulo, "Palestinos no contexto da imigração árabe para o Brasil", procura-se delinear o fenômeno da imigração árabe para o Brasil no qual se insere o imigrante palestino em Santa Catarina. Começa-se com um olhar sobre o início da mesma, tanto da emigração, quanto da imigração, e suas ondas migratórias distintas (uma antes e outra depois de 1950). Depois se busca compreender o fenômeno da inserção desses imigrantes no meio econômico, social e cultural do Brasil, tendo em mente as diferenças particulares desses grupos, já mencionados quanto aos períodos distintos (pré e pós-1950), mas que também possui uma diferença cultural relevante: ser predominantemente cristã no primeiro período e muçulmana no segundo.

O Segundo "Entre a Palestina e o Brasil: a trajetória migratória dos palestinos em Santa Catarina”, volta-se para o estudo mais específico dos palestinos em Santa Catarina no que se refere ao seu percurso, dos trajetos individuais e da identidade coletiva. A primeira parte do capítulo contextualiza o fenômeno da diáspora entre os palestinos. A segunda parte, 
“Êxodo da Palestina", refere-se à vida na terra natal e aos fatores que levaram a emigração. A terceira parte, "Inserção econômica", trata da inserção na economia brasileira. A quarta, "Inserção no meio sociocultural brasileiro", disserta sobre o tema da integração a cultura local, tanto a língua, quanto aos costumes. Por último, na parte sobre "Circulação migratória", é analisada a configuração do fenômeno migratório contemporâneo (ou o "ir" e "vir") entre palestinos em Santa Catarina e o papel das novas tecnologias informacionais e de transporte na manutenção dos laços com a terra de origem (o que será abordado também no capítulo seguinte sobre identidade).

No terceiro capítulo, "Identidades de uma diáspora: ser palestino e brasileiro em Santa Catarina", trata-se inicialmente da "A identidade palestina", título da primeira parte, e sua constituição ao longo de uma tribulada história através do século XX. Já a segunda parte explora a maneira como esses imigrantes veem o Brasil e sua inserção nele. A terceira parte, "Identidades sobrepostas", aborda a ambiguidade e a conciliação de uma identificação simultânea com a nação palestina e com a brasileira. 


\section{Palestinos no contexto da imigração árabe para o Brasil}

A imigração árabe para o Brasil é um fenômeno de mais de um século, cujas raízes remontam tanto aos processos de modernização particulares pelos quais passava tanto o Brasil do século XIX e início do século XX quanto o Império Otomano em suas últimas décadas, notadamente na região da Grande Síria (Bilad ash-Sham). A emigração para as Américas principiada por cristãos árabes da região do Levante em fins do século XIX tomou diferentes rumos com o passar do tempo e estendendo-se até a atualidade, mudando inclusive em seu perfil geral, passando de majoritariamente cristã para majoritariamente muçulmana após a Segunda Guerra Mundial, contexto em que se insere a maior parte dos imigrantes palestinos, mas também exibindo diversos traços de continuidade. Motivada sobretudo por questões econômicas, a imigração árabe para o Brasil se deu para os homens desde o começo até os dias de hoje como um empreendimento pessoal em busca de uma melhoria de vida, enquanto para mulheres tomou principalmente a forma de acompanhamento de parentes (Gattaz, 2005: 157). Por "empreendimento pessoal" não deve-se entender uma aventura para realização de interesses puramente individuais, pois os imigrantes em sua imensa maioria eram indivíduos comprometidos com laços familiares e o próprio processo migratório envolvia de modo geral decisões coletivas ou, ao menos, uma rede de acolhimento formada por parentes ou conterrâneos. A afirmação de Truzzi (2009: 43) para migração inicial vale em certa medida para o fluxo migratório mais contemporâneo: "A maior parte dos que emigravam o fizeram não com a decisão tomada individualmente, mas apoiados por uma base familiar ou, no mínimo, uma rede de conterrâneos”.

\subsection{Emigração}

Há dúvidas quanto o número exato de emigrados da região do Levante entre fins do século XIX e no início do século XX, período de maior surto migratório. Um relatório anual de 1889 das missões presbiterianas estrangeiras relata que num espaço de dois ou três anos 25 mil pessoas deixaram o Líbano pela América do Norte ou do Sul (Knowlton, 1961: 29). Estimativas consulares otomanas do ano de 1893 precisavam em 200 mil o número de seus cidadãos falantes do árabe nas Américas, subindo para meio milhão em 1912 segundo outras estimativas (Karpat, 1985: 183). No ano de 1900, cerca de 120.000 pessoas deixaram a Grande Síria rumo a América do Norte e do Sul; em 1914 cerca de 20.000 pessoas deixaram a 
região do Monte Líbano (Gattaz, 2005: 23). Estimativas para o êxodo migratório da Grande Síria entre 1860 e 1914 variam de 120 mil a 350 mil (Karpat, 1985: 183 \& Capello, 2004). Há cálculos que estimam que um quarto da população do Líbano emigrou entre 1990 e 1914 (Gattaz, 2005: 23; Knowlton, 1961: 17). Com base em todos os dados de saída e de entrada em diferentes países, é possível concluir, de acordo com Karpat (1985: 183), que o total de emigrantes que foram do Império Otomano para as Américas foi de um milhão e duzentos mil. Desses, aproximadamente 600 mil eram falantes do árabe do Monte Líbano e da Síria, tendo por volta de 280 mil imigrantes emigrado pelos portos de Beirute e Trípoli entre 19001914. Esses dados indicam um expressivo êxodo de um grupo em particular de todo o vasto Império Otomano. Para entender por que sobretudo cristãos do Levante, especialmente do Monte Líbano e arredores, formaram o bojo da emigração para as Américas, é preciso entender as características específicas dessa região e do processo modernizador particular por qual passava em fins do século XIX e início do século XX.

\subsubsection{Emigração árabe pré-1950}

O processo emigratório desencadeado nos territórios levantinos do Império Otomano no final do século XIX deve-se a uma série de transformações profundas que aconteciam no campo político, social, econômico e cultural. A região do Monte Líbano, que seria o epicentro das primeiras grandes levas migratórias, foi afetada de modo particular por essas mudanças. Distinta do resto do Levante pela sua configuração confessional singular, isto é, uma população majoritariamente maronita (corrente local do catolicismo) sobretudo no norte, com uma significativa população druza no sul, essa região montanhosa também tinha uma configuração sócio-econômica e política própria, com um amir ou hakim no alto da pirâmide social e logo abaixo famílias nobres (muqata’ji), ou lordes das montanhas, em sua maioria druzos, mas também alguns maronitas, ortodoxos e xiitas (Gattaz, 2005: 16). A relação entre essa classe de proprietário multiconfessional foi caracterizada por Hourani (2006: 366) como uma simbiose, já que os membros dessa classe, apesar das diferenças confessionais, compartilhavam interesses comuns, faziam alianças e possuíam relações formais entre si.

Em meados do século XIX, esse status quo foi perturbado por um conjunto de processos que se reforçavam mutuamente: crescente influência europeia e reformas modernizadoras. A partir das primeiras reformas modernizadora, realizadas inicialmente 
durante o domínio de Muhammad Ali e seu filho Ibrahim Pasha ${ }^{7}$ na Grande Síria, continuadas pelos otomanos, e o concomitante aumento da presença europeia, houve uma mudança do equilíbrio numérico e econômico entre maronitas e druzos em favor dos primeiros envolvia o enfraquecimento do poderio otomano em decorrência da hegemonia europeia. Isso acirrou diferenças comunitárias e confessionais entre os dois grupos, pois pelo menos desde o período das reformas supramencionadas, maronitas vinham substituindo druzos como agricultores nesta região levando estes a se deslocarem para região de Hauran, na atual Síria e parte da Jordânia. Os drusos que não deixaram a região se sentiam inseguros quanto a sua posição econômica, religiosa e política. A consequência dessa tensão foi o massacre de 1860 das vilas cristãs maronitas do Líbano por druzos, que provocou cerca de 10 mil mortes.

Segundo Knowlton (1961: 21), “os massacres de 1860 acarretaram mudanças drásticas nas instituições sociais, religiosas e políticas do Líbano e da Síria”. Uma das principais consequências desse massacre foi o aumento da interferência europeia (francesa e inglesa principalmente) que fez com que o governo de Istambul concedesse autonomia plena a região do Monte Líbano, sendo que a partir dali devia ser instituído um governador local (mutasarrif), que deveria ser um cristão não-libanês, nomeado pelo sultão e aprovado pelas potências ocidentais. Os privilégios tradicionais desfrutados pela elite proprietária de terra foram então extintos levando ao desfacelamento do poder das antigas famílias e senhores da montanha. Assim, os camponeses puderam usufruir de liberdade pessoal e propriedade da terra (Firo, 1995: 159-160), o que favoreceu a integração da economia local numa economia de mercado hegemonicamente europeia. Ainda assim, segundo Knowlton (1961: 21), havia ainda um clima de insegurança entre os cristãos que o penderam para proteção francesa ou para emigração para um país de maioria cristã.

O massacre teria sido apontado como uma das causas diretas do fluxo emigratório que surge na região em fins do século XIX. Apesar da controvérsia, Karpat 178) e Truzzi (2009: 30) notam que os massacres de cristãos por druzos ocorreram em 1860, enquanto o movimento migratório tomou fôlego a partir de 1880. As causas políticas para emigração, revoltas druzas e opressão otomana antes dos jovens turcos, é contraditória com muitas evidências que demonstram as maiores revoltas druzas (1840-1860) serem anteriores ao início da emigração: 1896 e 1909. Para Karpat (1985: 178-179)própria atitude dos emigrantes sírios, de desejar retornar após acumular algum pecúlio, contradiz as afirmações de opressão dos

\footnotetext{
${ }^{7}$ Muhammad Ali, um comandante do exército otomano, tornou-se governante autônomo do Egito na primeira metade de século XIX início reformas modernizadoras no país. Seu filho, Ibrahim Pasha estendeu seu domínio e suas reformas para região da Grande Síria (ver Hourani, 2006: e Kimmerling \& Migdal, 1994: 6).
} 
cristãos pelo Império Otomano como a principal causa da emigração. Já para Truzzi (1992: 12), apesar de constatar que a perseguição religiosa teria exercido diretamente no máximo um papel secundário, afirma que a maioria dos sírios e libaneses cristãos emigrou devido à precariedade de sua situação socioeconômica e o status inferior de minoria cristã numa região majoritariamente muçulmana, parte do vasto Império Otomano.

De qualquer forma, o acontecimento gerou um intenso debate no Ocidente e provocou o que Hourani (2006: 396) chamou de um dos primeiros exemplos de caridade internacional organizada dentro de um ideal de "fardo do homem branco" para com os "não-brancos", por essa razão, além de outras já citadas, fortalecendo o processo de modernização e aumento da presença ocidental no Líbano. O isolamento das vilas maronitas havia terminado não só com a chegada de missionários (que chegavam em número expressivo já no período de Ibrahim Pasha), mas também com a chegada de jornalistas correspondentes após os massacres. Seus relatórios sobre a condição dos cristãos ali reforçou os interesses e simpatias vindos da Europa e dos Estados Unidos, resultando no estabelecimento de novas missões de outras seitas cristãs. Com o tempo quase todas as aldeias cristãs do Líbano tinham pelo menos uma escola de missão e missionários residentes.

A presença missionária sem dúvida fortaleceram os vínculos daquela região com o Ocidente. Embora não forneça causas suficientes para provocar a emigração, ela trouxe informações sobre terras distantes com oportunidades econômicas e pôs com uma rede de contatos e informações que davam sustento a essa empreitada. Por sua vez, a emigração fortalecia o papel das escolas de missão que, por sua vez, ajudava a retroalimentar o ímpeto de emigração, como descreveu Knowlton (1961: 155):

\footnotetext{
A febre da emigração também conduziu centenas de alunos às escolas das missões para aprender inglês, métodos comerciais modernos, e para travar conhecimento com a mentalidade dos norte-americanos e europeus. Imigrantes que falavam o inglês progrediram nos Estados Unidos muito mais depressa do que os outros, tanto econômica como socialmente, como a maioria dos imigrantes nos primeiros tempos planejava ir para os Estados Unidos, as escolas das missões norte-americanas viviam abarrotadas. Muitos dos sírios e libaneses que emigraram para o Brasil tinham freqüentado essas escolas e adquirindo uma profunda confiança nos colégios e nos métodos de ensino norte-americanos.
}

A urbanização e subordinação econômica ao mercado europeu traziam grandes oportunidades e estímulos a uma agricultura comercial, que foi suplantando ou sobreponde-se a de subsistência. A relação entre cidade e montanha no Líbano, embora sempre tivesse sido uma relação de interdependência, atravessou uma mudança significativa durante o século XIX com a penetração que resultou na ascendência das cidades costeiras sob a montanha (Fawaz, 
1984: 489). Anteriormente, a tendência havia sido o contrário, mas esta situação de parceiro dominante não deixou de trazer desvantagens, como as tensões que vieram da montanha. Isto significava também vínculos que permitiam aos comerciantes uma maior ligação com os camponeses da cidade, lhe dando uma alternativa a dependência de seus senhores rurais através de empréstimos para uma agricultura mais especializada e voltada ao mercado.

A expansão considerável da área cultiva no Monte Líbano através de terraços e da difusão da pequena propriedade ficou centrada, entretanto, na produção de vinho, tabaco e seda, reduzindo a quantidade de terras disponíveis para o que acabou por gerar ciclos de fome pelo século XIX. Ainda assim, a população do Líbano cresceu mais do que qualquer outra da região, chegando a uma densidade demográfica de 159 habitantes por quilometro quadrado em 1900. Beirute cresceu de 5 mil a 120 mil habitantes do início do século XIX para o final do século XX. A sericultura que anteriormente servia mais ao ambiente doméstico e local, adaptava-se a demanda europeia, especialmente a da França. A influência francesa em conjunto com a modernização daquele território rompeu com o antigo estilo de vida baseado numa economia agropastoril de subsistência com a venda de excedentes para o mercado local. Enquanto em 1840 três quartos da produção de seda na região da Síria era consumida localmente, no ano de 1873 foi registrado que 40\% dessa produção se destinava à França, subindo para $90 \%$ por volta de 1900 e $99 \%$ pouco antes da eclosão da Primeira Guerra Mundial (Firo, 1990: 154). A região do Monte Líbano tornou-se após 1860 praticamente uma área de monocultura de seda, com cerca de $80 \%$ da área de cultivo coberta por amoreiras, planta que serve de alimento para o bicho-da-seda (Ibidem: 151).

A abertura do Canal de Suez facilitou a importação de seda do Japão, o que teria gerado uma queda no preço da seda e subsequentemente um empobrecimento para população maronita do Monte Líbano que havia se tornado dependente da renda advinda da seda (Firo, 1990: 161 \& Truzzi, 2009: 28). A destruição de vinhas pela phylloxera e uma epidemia de doenças que causou a morte de muitos dos bichos da seda teriam agravado ainda mais a situação econômica (Firo, 1990: 154-155 \& Karpat, 1985: 178). Ernesto Capello (2004) indica que essas dificuldades geradas para o comércio da seda naquela região após 1860 teriam induzido a emigração das terras do Monte Líbano e a dispersão da população maronita pelo Líbano, sobretudo para o sul, nas regiões de maioria druza (o que estaria na origem do conflito de 1860) e para Beirute. O excesso populacional teria levado a um exodo rural e quando as cidades não comportavam mais o crescente contingente vindo do campo, iniciou-se uma emigração do Líbano para outros continentes. 
Como é possível concluir, as causas da emigração de árabes da região do Levante correspondem aos padrões comuns aos europeus que passaram pelas mudanças econômicas e tecnológicas da época, sobretudo, que se retroalimentavam. A expansão econômica através de redes de transporte integrava a economia capitalista global, que ao mesmo tempo transportavam os bens industrializados que minavam o artesanato local, impulsionando a busca por alternativas econômicas e facilitavam a mobilização que era base para o fluxo migratório.

Alguns fatores políticos podem ser acrescentados ao que ao processo migratório que se deu sobretudo por causas econômicas, como a condição de minoria para os cristãos (ainda que privilegiada pelos europeus) e, durante um período específico, a conscrição militar obrigatório no período final do Império Otomano, fruto também de reformas modernizadoras. Antes de 1909, os cristãos não eram conscritos para serviço militar no Império Otomano, pela relutância dos muçulmanos em armá-los para dar-lhes a honra de portar armas. As dificuldades militares e políticas desse Império durante o século XIX e início do XX levaram a conscrição universal de todas as confissões religiosas (pode-se adicionar também as reformas modernizadoras). O tratamento rude que estes novos conscritos recebiam pelos oficiais e soldados muçulmanos levou milhares a optar pela emigração para fugir ao serviço militar.

Ao contrário das descrições feitas para explicar o êxodo da Síria e do Líbano no século XIX, caracterizando os países que viviam sob uma condição crônica de miséria e declínio econômico, reforçados pelas práticas de banditismo e extorsão de impostos (Knowlton, 1961: 24), as causas da emigração estão mais ligadas às contradições do processo de modernização pelo qual passava o país do que ao atraso. O Líbano era um país socioeconomicamente desenvolvido de modo inigualável na região, com melhor nível educacional proveniente da alta concentração de missões católicas e protestantes, além de uma pequena burguesia composta de comerciantes, agentes de companhias ferroviárias, marítimas e portuárias, professores, jornalistas, editores e oficiais de administração pública, empregados de bancos, hotéis e outros setores de serviços, proprietários de indústrias de processamento de seda, etc (Gattaz: 2005: 34). Possuía assim uma classe média muito mais consciente das possibilidades econômicas no Ocidente. Fatores como pestes, erosão do solo, crises econômicas, explosões demográficas e conscrição militar obrigatória agiram em conjunto para criar uma situação de pobreza (ou relativa pobreza), para qual a emigração surgia como saída.

A base da identidade desse povo (religião, aldeia e família) também teve seu papel no surto migratório (Truzzi, 2009: 32), sobretudo na manutenção do fluxo migratório e em sua 
expansão. Cada pessoa pertencia a uma religião, dentro da qual se delimitavam as comunidades e a autoridade religiosa. Esta questão exerceu um forte impulso para emigração na medida em que, além das pressões demográficas e econômicas, havia uma busca pela manutenção do status da família dentro de sua aldeia. Imigrantes que retornavam abonados de suas estadias na América ou que enviam remessas significativas geravam uma espécie de competição entre as famílias para tentarem elevar ou sustentar seu prestígio enviando seus filhos para fora do país. Essa deriva de uma noção clara que a honra da família é sempre igual ou maior que a do indivíduo (Truzzi, 2009: 35).

De certo modo, a emigração para América retroalimentava a relação com o dinheiro e com a economia de mercado estabelecidas em fins do século XIX. Desse modo, o dinheiro recebido era usado para compra de luxos antes dispensáveis, que pela atração (o fetiche da mercadoria) das benesses do consumo, levaram a emigração, que era uma resposta satisfatória a busca pelo dinheiro, a se tornar um elo quase indispensável na satisfação dessas necessidades. Cartas enviadas pelos emigrados a suas famílias revelam esse fascínio pelas perspectivas de enriquecimento.

Um dos relatórios de missionários cristãos americanos citado por Knowlton (1961: 30) descreve a febre migratória que fazia muitos alunos emigrarem ou desejarem fazê-lo, sendo especialmente inquietante para professores que viam um analfabeto enviar um cheque de volta de 300 ou 400 dólares após apenas seis meses na América, enquanto um professor ou um pasto não obtiam esta renda em salário em dois anos de trabalho. Também relata que chegava em Zahle da América em média 400 a 500 dólares por dia, dinheiro usado sobretudo para saldar dívidas e para levar outros além-mar.

O envio de remessas não só estimulava o fluxo migratório, como o financiava muitas vezes (Truzzi, 2009: 41). Isto tornou o correio um dos locais mais importantes das vilas. Em vilas menores a distribuição da correspondência era pública. Cartas comuns significavam apenas notícias, enquanto cartas registradas significavam notícias e dinheiro e por isso eram mais celebradas. Nota-se também como as notícias de ascensão econômica de patrícios no exteriores estimulava um processo de emigração, um "efeito corrente" que levava muitos a buscarem claramente um perspectiva de ganho e ascensão econômica, com perspectivas de retorno (Gattaz, 2005: 35)

Após a interrupção da emigração durante a Primeira Guerra Mundial, a emigração retorna com a frustração de não se obter a independência. Muitos imigrantes retornaram a seus países para averiguar a situação social e política, mas não se satisfaziam com o domínio francês, retornando a emigrar. Os relatos que fizeram da situação na terra natal levou muitos a 
não voltarem da terra de imigração para lá. Wadi Safady (1966: 96) relata que era comum os habitantes do Líbano e da Síria sofrerem humilhações dos militares franceses: mulheres muçulmanas terem seus véus retirados em público, homens terem seu charuto retirado da boca e pisado no chão por um soldado, etc.

Entretanto, o perfil da emigração começa a se alterar com o domínio francês, que claramente privilegiava os maronitas. Enquanto estavam sob domínio otomano, esses sentiram maior pressão para emigrar, o que teria diminuído após a instauração do Mandato francês e estimulado outros grupos (Knowlton, 1961: 59). Como na Síria ainda constituem, grupos minoritários, a pressão ali pode ter permanecido. Portanto, a emigração maronita do Líbano foi mais intensa pré-Mandato francês.

Apesar da região do Monte Líbano e arredores aparecer como centro pioneiro de emigração, Knowlton informa que "o movimento emigratório começou em Bethlehem (Belém) por volta de 1870 e aos poucos espalhou-se pela Síria e Líbano”. De modo geral, será na esteira desse fluxo migratório que a imigração palestina para o Brasil irá traçar o seu percurso, tanto no período pré-1950, quando no período posterior. Palestinos estiveram presentes durante os primeiros fluxos migratórios de árabes para o Brasil. De modo geral, não constituíram um processo à parte, nem proporcionalmente significativo no caso brasileiro. Knowlton (1961: 38) constatou em sua época que os palestinos "são considerados membros da colônia síria e libanesa. São virtualmente idênticos na cultura, origem étnica e religião". Entretanto, a afirmação é em parte questionável mesmo para o período anterior a 1950, já que Safady (1966: 303-304) informa que entre os 21 responsáveis pela fundação da Sociedade Beneficente Muçulmana de São Paulo no ano de 1929, a maioria eram palestinos da cidade de Safad. Entretanto, a maior parte dos palestinos que hoje residem no Brasil chegaram após a Segunda Guerra Mundial, partes de um fluxo migratório árabe que se caracterizaria por ser majoritariamente muçulmano.

\subsubsection{Emigração árabe pós-1950}

A imigração árabe pós-1950 e ainda em curso possui diferenças assim como semelhanças notáveis com as primeiras imigrações árabes para o Brasil. A primeira a ser notada é que permanece o caráter espontâneo da migração, sem agências ou projetos governamentais, mas via de regra alicerçada no apoio e na ajuda de familiares. Trata-se, como fora outrora, em sua maioria, de indivíduos do sexo masculino que emigraram de seu país de origem para encontrar melhores condições de vida em outro lugar com a determinação de 
voltar após ter acumulado recursos suficientes. Como já foi mencionado, as condições favoráveis ao estabelecimento final no Brasil e somadas as turbulências no país natal fizeram que muitos imigrantes árabes das primeiras décadas do século $\mathrm{XX}$ resolvessem se fixar no novo mundo e romper os laços com a velha terra.

Nisto se difere muito as gerações advindas nas últimas décadas que vivem num mundo cada vez mais globalizado com meios de transporte de alta velocidade, como trens e aviões, e meios de comunicação globais instantâneos, como telefone e mais recentemente a internet, que permitem estabelecer contatos constates e contínuos com o país e as comunidades de origem, mesmo a milhares de quilômetros. Informações sobre transformações políticas e sociais em diversos locais do planeta podem ser obtidas rapidamente e por meio de transporte aéreo é possível ir praticamente de qualquer país a outro em menos de um dia. Os sistemas de crédito internacional também facilitam esta ligação, permitindo enviar ou receber recursos a longas distâncias, além de outros benefícios comerciais. Enfim, as gerações de imigrantes árabes vindos após a Segunda Guerra Mundial vivem num planeta cada vez mais interconectado à longa distância e cada vez mais ao alcance de uma parte mais significativa da população. Possibilita-se estabelecer uma comunidade transnacional, com contatos constantes, ajudas e outras inter-relações à distância. Isso permite que a imigração deixe de ser um fenômeno tipicamente unilateral, aonde o imigrante deixa para sempre seu país para habitar em um novo, e se transforme numa migração transitória e transnacional, com constantes idas e vindas para o velho e o novo país com o passar das gerações.

\subsection{Imigração}

A imigração árabe para o Brasil se situa no contexto das grandes imigrações do século XIX ao início do XX, com o auge nos anos de 1880 a 1915, contribuindo decisivamente para este fluxo as mudanças tecnológicas nos meios de transporte e comunicação, como a navegação a vapor e a estrada de ferro. O contexto mais especificamente brasileiro era o da crise da escravatura e a substituição por uma mão-de-obra livre. Assim, buscou-se uma imigração sobretudo de caráter familiar e agrícola, voltada a preencher o vácuo ocupacional deixado pelo fim da mão-de-obra escrava.

Os primeiros sírios e libaneses começaram a chegar ao Brasil por volta de 1870. Os boletins do ministério do trabalho, indústria e Comércio informam que em 1871 teriam chego os primeiros imigrantes "do Oriente Médio" ("turcos”), confirmada pela estatística/censo de 1876 acusando a presença de três "turcos" na cidade do Rio de janeiro e no Estado do Rio 
Grande do Sul. Várias biografias revelam que seus autores já estavam no Brasil no início de 1880 (Knowlton, 1961:37). O auge deste primeiro fluxo o ano anterior ao início da Primeira Guerra Mundial com 11.101 entradas. Os primeiros fluxos foram irregulares e esparsos, sendo o mais constante após 1895, quando se adensou e cresceu de modo regular entre 1903 e 1913, quando alcançou a cifra supracitada (Truzzi, 2009: 45). "A princípio a imigração foi lenta e irregular. Durante o intervalo de vinte anos de 1871 a 1891, somente 156 sírios e libaneses foram registrados como tendo entrado no Brasil" (Knowlton, 1961: 37). Karam (2007: 10) cita a cifra de 140.00 entre e a média de 700 por ano após a década de 1970. Do total de mais de quatro milhões de imigrantes que entraram no país entre 1884 e 1943, os sírios e libaneses representaram 106.088 imigrantes, ou seja, 2,5\% da imigração registrada (Knowlton: 43).

\subsubsection{Imigração pré-1950}

O Brasil passava naquele momento, fins do século XIX, por um intenso processo de transformação sócio-econômica: a passagem de uma economia sustentada na mão-de-obra escrava para uma baseada no trabalho livre, sobretudo de colonos europeus. Essa transformação foi responsável pela formação de um mercado interno no Brasil. Evidentemente, já existia um comércio interno desde os tempos coloniais, porém, só em fins do século XIX inicia-se o processo de formação de uma economia de mercado, o que foi possibilitado pela monetarização da economia junto a uma pequena produção comercial dos excedentes agrícolas dos colonos. Na intermediação entre campo e cidade é que surgirá o principal espaço de inserção dos imigrantes árabes, sobretudo, através da atividade de mascate. Esta já era conhecida há séculos, contudo, estava mais integrada ao fornecimento para grande lavoura.

Com a formação de uma economia interna de mercado, o mascatear ganha uma nova dimensão, na medida em que vários colonos dispõem de excedentes para uma pequena comercialização. Este nicho econômico era mais permeável que o comércio urbano já há muito ocupado pelos portugueses e mais acessível aos que imigravam por conta própria e não através de projetos de colonização concebidos ou apoiados pelo estado brasileiro, o que dificultava o acesso a terra. Outro fator que induzia os imigrantes árabes a atividades comerciais fora as próprias diferenças geográficas, que não estimulavam estes a comprarem por si mesmo um terreno no qual não conseguiriam facilmente plantar os cultivos de clima mediterrâneo com que estavam acostumados. Entretanto, não era o comércio a principal 
atividade dos sírios, libaneses e palestinos que aportavam no Brasil em fins do século XIX e início do século XX.

Como na maior parte do mundo até o século XX, a região do Levante (Síria, Líbano e Palestina) era predominantemente rural. Também era o perfil da maior parte dos imigrantes daquela região. Não significa que, por se dedicarem principalmente a uma economia de subsistência, desconhecessem o comércio. Internamente, houve uma migração do campo para cidade que influenciou na trajetória dos árabes no outro continente. Mesmo que não passassem diretamente pela experiência de mudar para cidade, essa podia ser transmitida indiretamente, como uma experiência pedagógica que se transferiu para as primeiras gerações de emigrantes e destas para as seguintes gerações, e assim sucessivamente. Assim, ao chegar as Américas, o imigrante já poderia estar familiarizado com os princípios básicos de sua futura atividade. Exercê-la, entretanto, não deixava de ser um desafio. Não raro, casos de fracasso foram obscurecidos pelos de sucesso tanto econômico quanto social.

A trajetória dos emigrantes normalmente envolvia a escala em um dos importantes portos do mediterrâneo como Gênova, Marselha e Alexandria, viajando em navios italianos, franceses ou gregos até eles. Chegando aí, se instavam em um hotel ou numa pensão até a chegada do navio que os levariam a seus destinos finais. Frequentemente se esperava uma semana ou mais, até meses. Neste interstício, aproveitaram para se informar e trocar informações, buscando saber o(s) país(es) ao qual se dirigiam, não raro mudando sua rota original para outro país a conselho de outro emigrante com quem falava.

Agências de viagem buscavam persuadir os imigrantes a mudarem suas passagens compradas na síria ou no Líbano por outras mais baratas para destinos diferentes do original. Assim, um imigrante poderia desistir de ir para os Estados Unidos da América para ir ao Brasil ou a Argentina. Não era incomum os imigrantes serem explorados por todo tipo de gente que entraram em contato no caminho e acabarem serem por eles extorquidos de seu dinheiro.

Segundo Knowlton (1961: 65-66), havia no final no século XIX e início do século XX três grandes centros de atração para os imigrantes sírios e libaneses. Um era a bacia Amazônica, onde o mascate árabe seguia as rotas da economia da borracha, não pelo produto em si, mas para ali vender mercadorias. Como também no comércio com colonos do dentro do sistema de colonato, o mascate árabe servia como uma alternativa ao armazém do grande proprietário (ver outro nome), uma ruptura ainda mais acentuada com o status quo na Amazônia do auge da economia da borracha, onde o trabalho se dava por um escravidão por dívidas (verificar Truzzi). Outro centro era São Paulo, especialmente a capital, que florescia 
economicamente com a lavoura do café, seguida do desenvolvimento industrial, atraindo imigrantes de todas as partes do mundo. Os imigrantes sírios ou libanês estabeleciam-se em algum lugar favorável para abrir uma lojinha. Por razões análogas, também foram atraídos para o estado de Minas Gerais. Com o declínio da prosperidade da borracha, muitos árabes abandonam a região amazônica por São Paulo e Rio de Janeiro. Santa Catarina aparece como um dos Estados de menor penetração do grupo sírio-libanes, juntamente com Estados que na época tinham baixo desempenho econômico e que, por isso, atraíram poucos imigrantes árabes. Segundo o Knowlton (1961: 67), isso se devia a dificuldade de se fixar em comunidades alemãs, então preponderantes no Estado.

A imigração para o Brasil surgia para os sírios e libaneses mais como uma necessidade do momento, uma solução temporária para as necessidades econômicas. Apresentou-se de forma espontânea, sem auxílio do Estado de origem ou de chegada e sem suporte de empresas e agências de imigração e colonização. Mais de $63 \%$ dos imigrantes registrados como turcos eram solteiros ao entrarem no Brasil (Knowlton 1963: 51). Por influência ou consequiência desta falta de apoio por parte de empresas e dos governos define o caráter essencialmente urbano da imigração, pois não houve muitas tentativas dos imigrantes sírio-libaneses de adquirem propriedades rurais e se estabelecerem no campo, outro aspecto divergente de outros grupos de imigrantes. E assim poucos vinham com a intenção de ficar, de constituir raízes, de achar um novo lar. No entanto, devido a uma situação favorável para se estabelecer e desfavorável para retornar, muitos acabaram por se fixarem no Brasil. Na visão típica desses imigrantes isto era o que o destino lhes havia reservado, tinha que ser assim, "está escrito" (maktub).

O grupo classificado nas estatísticas oficiais como "turco-árabe" apresenta taxas de permanência mais baixas antes de 1920, refletindo já mencionada perspectiva de "fazer a América", apresentando taxas de retorno de 46,17\% do total da imigração. (Knowlton, 1961: 50). Este padrão manteve-se, sobretudo, durante o período inicial da imigração, nas duas primeiras décadas desta entre 1890 e 1910 . As vantagens materiais da permanência no mahjar (local de imigração) somado as dificuldades e penúrias sofridas pela população rural, especialmente durante a Primeira Guerra Mundial, que além de provocar um bloqueio à importação de alimentos às terras otomanas pelos aliados, juntamente aumentava a necessidade do exército otomano por suprimentos, levando a um grande confisco da produção local de trigo e outros grãos. Para os cristãos também havia sido estendido o serviço militar e as tensões internas levaram a criação do Protetorado francês, o que ajudou a precipitar a emigração. 
Knowlton (1961: 98) repara que os muçulmanos (chamados de maometanos pelo censo de 1920) eram um grupo diminuto, que não participam plenamente das atividades da colônia árabe de modo geral (pode-se dizer pelo modo como concentram-se em clubes e associações religiosas/comunais, isto é, do local de origem). Notabilizavam-se pelo fato de predominar homens, com um grande escassez de mulheres (praticamente 3 homens para cada mulher segundo o censo). Portanto, como sugere Knowlton, os que desejam casar-se em usa maioria devem escolher mulheres cristãs. Isso significou que os filhos em sua grande maioria desses casamentos interconfessionais tornaram-se cristãos ou não tiveram formação religiosa alguma. Há também aqueles que preferiram permanecer solteiros a desposar cristãs.

Em 1940, registravam-se 3.053 "maometanos” (muçulmanos) no Brasil. Entretanto, Knowlton (Ibidem: 102) repara na época que grupos muçulmanos tivessem entrado recentemente no Brasil. Analogamente, Wadi Safady (1966: 308) informava que durante 10 anos anteriores ao período em que escrevia "a imigração dos muçulmanos aumentou consideravelmente no Estado do Paraná”. Era o princípio da segunda onda migratória árabe para o Brasil, a que veio a caracterizar-se por ser predominantemente muçulmana e ter iniciado no período após a Segunda Guerra Mundial, onde se insere a trajetória dos imigrantes palestinos de Santa Catarina.

\subsubsection{Imigração pós-1950}

A imigração árabe dos últimos 40 anos e ainda em curso possui diferenças assim como semelhanças notáveis com as primeiras imigrações árabes para o Brasil. A primeira a ser notada é o caráter espontâneo da imigração árabe, sem agências ou projetos governamentais, mas frequentemente com o apoio e a ajuda de familiares. Trata-se, como fora outrora, em sua maioria, de indivíduos do sexo masculino que emigraram de seu país de origem para encontrar melhores condições de vida em outro lugar com a determinação de voltar após ter acumulado recursos suficientes. Como já foi mencionado, as condições favoráveis ao estabelecimento final no Brasil e somadas às turbulências no país natal fizeram que muitos imigrantes árabes das primeiras décadas do século $\mathrm{XX}$ resolvessem se fixar no novo mundo e romper os laços com a velha terra.

Nesse aspecto, a imigração pós-1950 e contemporânea se difere muito das gerações advindas nas últimas décadas que vivem num mundo cada vez mais globalizado com meios de transporte de alta velocidade, como trens e aviões, e meios de comunicação globais instantâneos, como telefone e mais recentemente a internet, que permitem estabelecer 
contatos constates e contínuos com o país e as comunidades de origem, mesmo a milhares de quilômetros. Informações sobre transformações políticas e sociais em diversos locais do planeta podem ser obtidas rapidamente e por meio de transporte aéreo é possível ir praticamente de qualquer país a outro em menos de um dia. Os sistemas de crédito internacional também facilitam esta ligação, permitindo enviar ou receber recursos a longas distâncias, além de outros benefícios comerciais. Enfim, as gerações de imigrantes árabes vindos após a Segunda Guerra Mundial vivem num planeta cada vez mais interconectado à longa distância e cada vez mais ao alcance de uma parte mais significativa da população. Possibilita-se estabelecer uma comunidade transnacional, com contatos constantes, ajudas e outras inter-relações à distância. Isso permite que a imigração deixe de ser um fenômeno tipicamente unilateral, aonde o imigrante deixa para sempre seu país para habitar em um novo, e se transforme numa migração transitória e transnacional, com constantes idas e vindas para o velho e o novo país com o passar das gerações.

Os primeiros ao chegar não possuíam o mesmo acesso a esses meios de comunicação e transporte ainda não tão desenvolvidos e massificados no Brasil e no Oriente Médio. Inicialmente, estes tiveram de passar anos sem qualquer contato com seus familiares. Mas com a maior difusão desses meios de transporte, comunicação e avanços da tecnologia, somados a uma maior abertura do Brasil ao mercado externo no início da década de 1990, muitos puderam reencontrar seus parentes e sua terra natal.

As possibilidades de transumâncias oferecidas pelos meios de transporte mais modernos de alta velocidade permitem o fácil deslocamento para outros centros e região que facilitam o retorno e a reintegração a terra natal, mesmo que temporário. Assim se verificou inúmeros casos de idas e vindas para Jordânia, Palestina ou Líbano, seja para morar um tempo lá e estudar, seja para casar ou ter filhos.

Quanto aos números de árabes muçulmanos no Brasil, as estimativas variam imensamente. Enquanto o IBGE, no censo de 2000, registrou apenas pouco mais de 27 mil muçulmanos (IBGE, Censo Demográfico 2000), as entidades muçulmanas costumam adotar o número de um milhão a um milhão e meio, sendo o número mais plausível algo entre 400 mil a meio milhão de muçulmanos, segundo uma comunicação diplomática da embaixada americana sobre os muçulmanos no Brasil revelada pelo Wikileaks ${ }^{8}$.

\subsection{Inserção econômica}

\footnotetext{
${ }^{8}$ http://cablegate.wikileaks.org/cable/2009/11/09SAOPAULO653.html acesso 29/11/2010
} 
Como na maior parte do mundo até o século XX, a região do Levante (Síria, Líbano e Palestina) era predominantemente rural. Também era o perfil da maior parte dos imigrantes daquela região. Não significa que, por se dedicarem principalmente a uma economia de subsistência, desconhecessem o comércio. Internamente, houve uma migração do campo para cidade que influenciou na trajetória dos árabes no outro continente. Mesmo que não passassem diretamente pela experiência de mudar para cidade, essa podia ser transmitida indiretamente, como uma experiência pedagógica que se transferiu para as primeiras gerações de emigrantes e destas para as seguintes gerações, e assim sucessivamente. Assim, ao chegar as Américas, o imigrante já poderia estar familiarizado com os princípios básicos de sua futura atividade. Exercê-la, entretanto, não deixava de ser um desafio. Não raro, casos de fracasso foram obscurecidos pelos de sucesso tanto econômico quanto social.

\subsubsection{Mascateação}

Os imigrantes sírios e libaneses em seus países de origem pequeno agricultores que cultivavam seus próprios pequenos lotes de terra. A atividade de mascate era lá realizada frequentemente por gregos, armênios e judeus. No Brasil, especialmente no Sudeste onde se concentrou a maior parte, estes se deparam com um sistema de grande lavoura. Alguns tentaram se integrar como colonos, mas o tratamento lá recebido e a falta de perspectiva de melhoria contribuíram para que outros, através dos relatos destes, também se mantivessem afastados da agricultura. As entradas pelo porto de Santos entre 1908-1939 registram que a maior parte dos sírios e libaneses não se apresentavam como agricultores, embora fosse a atividade predominante na terra natal, provavelmente por não pretenderem exercê-la no Brasil (Truzzi, 2009: 51).

$\mathrm{Na}$ inserção na nova sociedade, o mascatear não era apenas um meio de vida, mas uma atividade pedagógica, pois permitia aos poucos uma familiarização com a língua e os costumes locais. Em algumas regiões de forte colonização alemã ou italiana, isso significou uma familiarização com línguas que não a portuguesa. De qualquer forma, a maior concentração dessa atividade, e, portanto, da imigração árabe se deu em locais onde a monetarização e a colonização foram mais intensas, assim como as aglomerações urbanas que fornecessem as mercadorias para se vender. Este é o caso de São Paulo, onde todos esses fatores confluíram para gerar uma maior concentração e, especialmente na cidade de São Paulo, constituição de uma comunidade de sírios e libaneses. Na medida em que se 
acumulava capital suficiente era possível estabelecer-se na cidade, estabelecendo alguma loja de armarinhos ou de secos e molhados. Novamente, na cidade de São Paulo, com sua forte urbanização e indústria nascente, se revelou uma das condições mais promissoras ao estabelecimento de um comércio urbano. Ali também se verificou o maior número de comunidades e organizações de imigrantes, assim como uma maior preservação da língua e dos costumes. Apesar de extensivamente verificada, essa trajetória não de forma alguma homogênea ou a única possível. Há até evidências de sírios e libaneses que se dedicaram ao plantio de café em São Paulo, revelando nesses casos particulares, trajetórias possivelmente muito diferentes da apresentada.

$\mathrm{Na}$ busca de um enriquecimento rápido e sem muitos conhecimentos sobre o país em que haviam chegado, partiram para atividades comerciais, em primeiro lugar a de mascate. A estranheza do solo, do clima, das técnicas de cultivo e das plantas cultivadas, além das dificuldades para se comprar um pedaço de terra e o caráter passageiro da imigração para os sírios e libaneses que vinham sozinhos explorar as terras tropicais em busca de uma melhoria em sua condição de vida, favoreceram a opção pelo mascatear. Era pegar a trouxa, encher com algumas bugigangas e outras mercadorias para depois sair errante em busca de compradores aqui e acolá. Assim iam se difundindo das zonas portuárias para as periféricas, das cidades maiores para as cidades menores, seguindo a estrada de ferro pelo interior quase isolado e quase intocado pelas novidades que o mundo urbano gerava a cada instante. No entanto, para muitos de seus descendentes, é o "dom" para o comércio herdado diretamente dos fenícios que explica a sina dos libaneses na América. Por outro lado, Lesser (2001: 99) explica que:

Embora os imigrantes do Oriente Médio não fossem os primeiros estrangeiros a trabalhar como caixeiros-viajantes (por boa parte do século XIX, os imigrantes portugueses eram associados a essa atividade), o uso da etnicidade para construir vínculos comerciais atacadistas e varejistas criou economias de escala que eram totalmente novas. Eram as relações pessoais que permitiam aos mascates sírios e libaneses obter crédito, que por sua vez eles repassavam a seus clientes, uma inovação radical num país que apenas recentemente havia trocado o trabalho escravo pelo assalariado.

Aonde chegasse, a mascateação era a primeira atividade por excelência. Após arrecadar um "dinheirinho", se procurava, então, fixar numa lojinha, "deixar de ser trouxa":

Ao chegar ao Brasil, libaneses e sírios, árabes em geral, começam mascateando, trouxas ao ombro, sorri e acrescenta, só bem mais tarde irão tomar conhecimento do outro significado da palavra trouxa. Se estão se dando bem e mascatear dá certo, vão deixar de ser trouxas, não demora adquirem um cavalo, uma carrocinha, depois podem ter uma vendola, um armazém, loja de tecidos, quem sabe uma fabriqueta...

(Miguel, 2004: 82) 
A atividade do mascate, apesar do esforço de levar as mercadorias pesadas inicialmente nos ombros e nas costas à pé, só para depois de acumulado capital suficiente conseguir um burro para ajudar no transporte, oferecia um bom começo para um imigrantes que chegava desempregado, sem terras ou outros bens, além de poder ser exercida com um conhecimento apenas rudimentar da língua portuguesa, considerando ainda que muitas regiões também eram habitadas por colonos. Além disso, diferente das classes trabalhadoras rurais e operários, não havia um limite pré-estabelecido para ascensão social, em o problema do desemprego.

Os fornecedores dos mascates também eram, de forma geral, patrícios que adiantavam as mercadorias, para depois de vendidas serem pagas. Outro fato era que estes também havia tido a experiência de trabalharem como mascate, compreendendo as dificuldades e transmitindo conhecimentos práticos e habilidades, sendo por estas, entre outras razões, algo que facilitava o relacionamento entre mascate e fornecedor. Importante também era o desprendimento característico da atividade, demonstrada pela possibilidade de se ter mais de um fornecedor ao mesmo tempo. Era também algo temporário, uma passagem, o que era compreendido conjuntamente pelo mascate e pelo fornecer. Portanto, a priori, não havia restrições envolvendo a atividade de mascate, especialmente entre os membros da colônia.

Havia também a questão do retorno rápido, baseado no trabalho individual, o que estava de acordo com a perspectiva de retorno bem-sucedido a terra natal, especialmente anteriormente à Primeira Guerra Mundial, daqueles que vinham sozinhos e solteiros. Os que retornavam achavam difícil muitas vezes permanece, tendo as possibilidades do Brasil, por isso não foram poucos os que casaram e depois voltaram a emigrar. Daí o padrão da busca de noivas na terra natal, comum entre os pioneiros. Quando o retorno efetivamente não acontecia, havia o envio de remessas.

\subsubsection{Ascensão socioeconômica do grupo sírio-libanês}

A atividade de mascate foi fundamental na caracterização do imigrante árabe no Brasil, como também serviu instrumentalmente para ascensão social tanto individual quando coletiva. Além de não requisitar grande soma de dinheiro ou outros recursos, não era necessário mais que um conhecimento rudimentar da língua portuguesa para exercê-la. À medida que o capital dos imigrantes árabes deslocava-se da mascateação para o varejo, os laços (vínculos) tanto familiares quanto comunitários permitiu um funcionamento integrado verticalmente dentro de um sistema que ia desde a indústria (em um período posterior) até o 
comércio varejista (já nas etapas iniciais). Assim, a indústria e atacado supriam mercadorias para uma ampla rede varejista e de comércio ambulante.

Fator importante para ascensão socioeconômica de sírios e libaneses foram os laços de solidariedade e as redes de apoio mútuo (complementaridade e entreajuda). Isto ia desde a acolhida dos recém-chegados, inserção deles nas atividades comerciais da colônia até a relações complementares entre grandes comerciantes e industriais. Como fator de interconexão socioeconômica existiam vários mecanismo, como a disponibilidade e a facilidade de crédito, de fornecimento e entrefornecimentos dentro de ma rede comercial interétnica, que lhes dava sustento recíproco. Assim, uma rede de produção e comercialização vertical começou a se estruturar com base na etnia, com industriais e atacadistas suprindo uma ampla rede de varejistas e comerciantes ambulantes da mesma etnia.

Porém, estas inter-relações nunca se institucionalizaram, como acontecia entre muitos grupos de imigrantes, em uma câmara de comércio até a década de 1950. É percebível que nesta busca individual por fazer a vida pessoal e familiar havia pelas próprias características dessa empreitada, uma cultura de cooperação informal, que não buscava formular vínculos de dependências formais e impessoais. Isso talvez operasse como uma espécie de proteção aos riscos característicos do empreendimento comercial, por isso o provérbio cunhado pela colônia registrado por Truzzi (2009: 67): "todo libanês é brimo até a brimeira falência".

As dificuldades e sofrimentos pelos quais imigrantes da primeira geração passaram ao exercerem a atividade de mascate até conseguirem se estabelecer como lojistas, teria levados muitos a não desejarem a mesma condição penosa para seus filhos no futuro. O filho tornar-se doutor servia ainda mais como uma compensação pelos anos de labuta e pela vida sacrificada. Entretanto, principalmente no caso de negócios muito prósperos, havia a necessidade de continuidade que, devido ao fato dos colonos via de regra buscarem ter muitos filhos, fazia com que ao menos um fosse incumbido dessa missão. Esse não poderia dar-se ao luxo de estudar e deveria aprender com o pai no dia-a-dia enquanto o mesmo conduzisse a firma, empresa ou loja, entre outros negócios.

Entre os fatores que contribuíram para o ingresso de descendentes de imigrantes sírios e libaneses nas escolas superiores, espaços tradicionais da elite nativa, pode-se destacar a rápida ascensão econômica propiciada pela trajetória esquematizada, no esquema de Truzzi (1992: 84), como “mascate/pequeno comércio/comércio por atacado/indústria”.

Assim, com a ascensão econômica, muitos imigrantes puderam pagar uma boa educação para seus filhos, que por sua vez deveriam ingressar em profissões liberais, preferencialmente medicina e advocacia. Assim os filhos de "meros" mascates iam seguindo 
uma carreira que ia levando a ascensão social, visto a posição destacada dos bacharéis na sociedade brasileira. Após comparar inúmeros casos, Truzzi $(1992,111)$ conclui que:

\begin{abstract}
Os sírios e libaneses foram portanto em geral muito bem sucedidos no comércio e nas profissões liberais, em particular na medicina. A história social da colônia evidencia a conquista de um setor comercial importante na São Paulo das primeiras décadas do século e como isso possibilitou a entrada maciça de seus filhos no mercados das profissões liberais.
\end{abstract}

Entretanto, a ascensão e o sucesso como a marca da "raça" sírio-libanesa (ou fenícia) é uma visão que simplifica os fatos e ignora os percalços percorridos e agruras sentidas na trajetória de imigração, assentamento e adaptação, como Salim Miguel (2004: 82) escreve em seu romance memorialista sobre a vida de seu pai José:

(...) bem poucos enriquecem, mas as novas gerações acabam por esquecer os sacrifícios dos pais, dos que não tiveram nasib, some a vez dos perdedores, dos tarragada que não deram certo, dos fakir, os pobres, e o que fica, para os que estão querendo aventurar, é a fama dos raros que fizeram fortuna na boa terra, animando outros para que se aventurem, pois se a derrota se mantinha esquiva, a vitória era trombeteada.

\title{
1.3.3 Trajetória econômica de imigrantes árabes pós-1950
}

A atividade de trabalho exercida pelos imigrantes árabes foi de forma geral, tanto hoje como outrora, o comércio. Novamente o mascatear foi restabelecido por estes novos imigrantes, embora já haja uma discrepância considerável dos sírios e libaneses que vinham de pequenas comunidades rurais, os árabes das imigrações mais recentes provém de camadas urbanas, como professores, funcionários públicos, etc. A familiaridade com o comércio e a vida urbana é maior para estes imigrantes mais recentes, que muitas vezes nasceram neste ambiente urbano. Reinventou-se, portanto, o antigo "mito do mascate", em que a trajetória necessariamente destinada aos imigrantes árabes recém-chegados era este tipo de comércio. Existe, no entanto, uma possibilidade de desempenhar atividades urbanas já praticadas anteriormente na terra natal que quase não havia para os imigrantes sírio-libaneses do começo do século XX, ainda assim ela é mais teórica do que prática, porque a grande maioria ainda se volta para o comércio.

A escolaridade é mais presente nesses grupos do que nos que vieram no início do século XX até a década de 40. Evidentemente, os investimentos e acesso a escolaridade estão muito mais difundidos hoje do que naquela época nos países do Oriente Médio, embora sejam poucos os imigrantes pós-1950 que chegam com nível de ensino superior completo. A segunda geração já tende a receber maior grau de escolaridade, como fora então entre os 
descendentes de sírio-libaneses, mas ao contrário destes, poucos árabes muçulmanos que chegam aqui formados parecem exercer sua especialidade de formação, preferindo permanecer nas atividades e negócios comerciais herdado dos pais. Outro fator a ser lembrando é o curto prazo dessa imigração recente de árabes muçulmanos se comparada às primeiras imigrações árabes ao Brasil que chegaram já no início do século XX e possuem descentes de $4^{\mathrm{a}}$ e $5^{\mathrm{a}}$ geração. Entre os palestinos e libaneses que chegaram o Brasil na segunda metade do século XX, não há ainda uma expressiva terceira geração de imigrantes, não só pelo curto período de tempo, mas também devido à inconstância na fixação em um único território, levando a uma contínua transumância migratória com um contínuo retorno a terra natal e regresso a terra de imigração.

\subsection{Inserção sociocultural}

Devido estarem sob domínio otomano, os primeiros imigrantes árabes do Levante, chegando ao Brasil com passaportes emitidos pelas autoridades turcas, acabavam sendo associados como "turcos". Sobretudo para aqueles que ressentiam a soberania otomana, ser identificado com o dominador causava imenso dissabor. A denominação servia para distinguir esses imigrantes árabes de outras etnias e dos nativos, embora, excetuando o caso de judeus sefarditas da Turquia, a imigração propriamente turca para o Brasil tenha sido praticamente nula. Embora sírios quisessem ser chamados de sírios e libaneses de libaneses, a sociedade nativa não tinha como distinguir aqueles que, além de compartilhar uma mesma língua nativa (um dialeto muito próximo, ainda por cima), dedicavam-se de modo semelhante ao comércio e cozinhavam os mesmos pratos que foram incorporados a cozinha brasileira.

\subsubsection{Sírios e libaneses}

A integração dos imigrantes árabes à sociedade brasileira foi um processo que envolveu a confluência das atitudes dos imigrantes e características autóctones. Politicamente, o país estava aberto à imigração desde meados do século XIX até pelo menos a década de 1940. Evidentemente, a imigração árabe não constava nos projetos coloniais dos homens de estado, muito mais interessados na mão de obra europeia, tendo em vistas um branqueamento da população do Brasil. Entretanto, os fenótipos dos sírios e libaneses não se distinguiam de uma sociedade marcadamente miscigenada, mesmo nas camadas mais altas, como também se assemelhavam a de portugueses e italianos de regiões mais ao sul. $\mathrm{O}$ fato de falarem com 
algum sotaque o português também não se destacaria frente à miríade de imigrantes falantes de outras línguas. Além disso, houve um esforço consciente de muitos imigrantes árabes no Brasil com vistas à assimilação, o que alguns estudiosos chamaram de "suicídio cultural". Não raro, isso significou um abandono do idioma árabe mesmo no ambiente doméstico. Apesar disso, muitos elementos da cultura cotidiana acabaram sendo transmitidos, notavelmente a culinária.

Um elemento peculiar da sociedade brasileira foi também um fator em prol desse processo de integração, conhecido pela tipificação de "homem cordial" e que apresenta como característica principal o pessoalismo. Isso significa uma atitude que sobrevalorização as relações interpessoais e uma quebra das formalidades no trato, buscando-se uma aproximação direta que dispensa qualquer ritual e funciona como uma relação de amizade, embora possa ser por puro interesse. No que concerne a relação entre grupos socialmente ou culturalmente claramente distintos, isto pode significar uma "suspensão" dos estereótipos e preconceitos gerais ou particulares face ao relacionamento pessoal, colocando o particular acima do genérico. A partir dessas experiências é possível criar uma impressão de aceitação da diferença ou a inexistência de qualquer preconceito. Não significa, ao mesmo tempo, que não haja preconceito, assim como não haja uma fácil aceitação, mesmo que num nível pessoal, de diversos grupos ou de indivíduos de um grupo particularmente estigmatizado.

Este conjunto de fatores torna difícil a percepção ou mesmo a existência de uma discriminação em relação a estes imigrantes, sem considerar também aspectos de classe, do local ou do momento histórico. Certamente houve um estereótipo da figura do "turco", como os imigrantes sírio-libaneses ficaram conhecidos, devido às primeiras gerações que vieram com passaportes do império otomano. Este estereótipo, quando não preconceito, estava ligava-os à avareza ou à mesquinhez com o dinheiro, fenômeno que pode ter origem nos estigmatização dos povos semitas advinda de tempos medievais e recorrentes no pensamento da época, como na prática já calculada de acumulação de capital para trazer a família da terra natal ou para estabelecer como comerciante urbano.

A alcunha de "turco" em particular não é por si só um termo pejorativo, pois apesar de poder ser usado pejorativamente, é um termo que tem sua origem e continuidade na desinformação. É fruto também de uma falta de afirmação da identidade desses imigrantes que fosse vigorosa o suficiente para quebrar com a velha terminologia.

A integração dos árabes na sociedade brasileira não foi, no entanto, uma via de mão única, pois estes também deixaram as marcas de sua passagem. A própria cultura árabe já estava presente no legado ibérico da colonização do Brasil. Por mais que se tenha tentado 
conscientemente ou inconscientemente reduzi-los ou eliminá-los, esses traços permaneceram presentes no vocabulário, em costumes e nos próprios cultivos agrícolas tão fundamentais para formação econômica brasileira. Da mesma maneira que o árabe foi "absorvido" pela cultura local, esta "absorveu" muitos elementos deste, que se espalharam com eles por todo o país. Notabiliza-se o caso da culinária, que não foi somente preservada no ambiente domestico dos imigrantes e descendentes, como também disseminado para toda sociedade, de forma que se pode encontrar quibes e esfihas por lanchonetes em todo Brasil. O legado dos sírios e libaneses no Brasil pode ser visto principalmente em grandes metrópoles como São Paulo, que reúnem clubes, associações, restaurantes e mesmo locais marcados pela presença árabe, como a rua 25 de março.

As relações entre os grupos formavam-se ao chegar. Primeiramente, como de costume, vinha um filho, um pai, um primo. Percebendo-se em uma situação favorável e razoavelmente segura chamava outros membros da família, que podiam vir encantados pelos relatos admiráveis que seus parentes lhes contassem ou forçados pela má situação na terra natal, que podia pesar muito mais que as dúvidas na expectativa de sucesso e enriquecimento. Chegando ao Brasil, procurava-se terreno favorável, aonde tivesse um parente, amigo, primo, patrício, as teias de solidariedade iam se formando. A solidariedade poderia vir de várias formas, um empréstimo, uma moradia temporária, uma parceria nos negócios, etc. O casamento entre patrícios era outra forma de preservar a comunidade e ao mesmo tempo mantê-la unida entre os seus. Era tão importante, que no Anuário Demográfico de 1927 os sírios e libaneses apresentavam a segunda maior taxa de endogamia: 50,5\%, superados apenas pelos japoneses, com 63,2\% (TRUZZI, 2001: 05).

A “assimilação" à sociedade brasileira não foi simples, foi gradual, com suas nuances próprias. O primeiro obstáculo era claro, a língua. Os traços étnicos que distinguiam este grupo podiam identificá-los, mas não foram grandes obstáculos à assimilação e a ascensão social. Sendo o Brasil uma sociedade de mestiços, a pele morena e outros traços poderiam ser confundidos pelos de muitos portugueses e outros "brancos". Porém, a tradição, os hábitos trazidos de fora, isso podia ser facilmente estranhado. A diligência e zelo com o dinheiro, geravam estereótipos como o de sovina, de espertalhão, de ladrão, frequentemente associado aos comerciantes e banqueiros, como aos povos historicamente associados a estas práticas, como os judeus. Piadas não faltam aonde exista um "turco", o "mão-de-vaca". No processo de adaptação e assimilação várias tradições e hábitos foram sendo perdidos e não transmitidos às gerações posteriores. A língua e as vestimentas eram claras barreiras à assimilação e a integração, criava uma diferenciação evidente entre o imigrante e o brasileiro, o "nativo", este 
tão acostumado com as relações pessoais, de proximidades, pois o mero interesse econômico e comercial não garantiria a confiança e o respeito. Tudo que o distanciavam do "natural da terra", precisava ser evitado ou escondido em vista ao sucesso financeiro e a integração social. A identidade, então pode se manter apenas no espaço privado, dentro de casa, na cozinha, nos móveis, etc.

A identidade coletiva do grupo se enfraqueceu com o passar das gerações se misturando e se diluindo com o resto da sociedade e se espalhando pelos mais diversos confins, exceto em locais com grande número de imigrantes reunidos em um mesmo local, como a Colônia Sírio-Libanesa de São Paulo. Mesmo a solidariedade do grupo dos tempos de acolhimento e ajuda dos patrícios desfez-se com o passar do tempo, mantendo-se apenas resquícios através da identidade particular, os vínculos com o passado sírio ou libanês. De forma geral, a comunidade sírio-libanesa no Brasil se mantinha através de laços de solidariedade entre patrícios e parentes. O vínculo familiar era o que dava força, que acolhia e mantinha os sírio-libaneses, sua identidade e sua existência em uma terra desconhecida.

Membros proeminentes da comunidade árabe no Brasil frequentemente esposavam um meio termo entre as culturas árabe e brasileira redefinindo sua etnicidade dentro do panorama nacional(ista) brasileiro/a, colocando-se como mais "brasileiros" que maioria dos brasileiros (Lesser, 1996: 47). Intelectuais da colônia enalteceram e exaltaram a contribuição dos árabes na construção da nação brasileira na Era Vargas. Tudo que podia ser atribuído então à raça de "turcos" espertalhões e sovinas era invertido, e glorificado como qualidade que impulsionava para o progresso o Brasil. O trabalho, o esforço, a parcimônia, características herdadas dos fenícios. O libanês e o sírio trazem o sangue semita do comércio, que impulsiona a roda do progresso, da modernidade, gerando riquezas e desenvolvimento para o país que o acolheu. Estes imigrantes de tão longe acolheram o país que os acolheu, e a ele oferecem todos os seus dons para ajudar a desenvolvê-lo. A nação brasileira, por sua vez, também aceita o sírio, o libanês, como um de seus preciosos filhos, que enriqueceu o cadinho étnico tão característico do Brasil. Não são estrangeiros, e sim nacionais que carregam uma marca distinta que favorece a nação. Estes discursos ainda repercutem nos descendentes de sírios e libaneses que trazem o orgulho de sua ancestralidade como uma marca de destaque.

Entretanto, de modo geral, a integração e miscigenação a sociedade diluiu a maior parte dos elementos culturais e a identidade étnica dos descendentes desse grupo frente à sociedade brasileira na qual se imiscuíam. Em sua dissertação de Mestrado em História, Carvalho sustenta que a preservação da identidade sírio-libanesa entre os descendentes mais dispersos, deu-se pela culinária. A culinária foi o elemento comum verificado entre as pessoas 
que possuíam ascendência sírio-libanesa na Grande Florianópolis como aspecto distintivo e revelador da ancestralidade, de pertença ao grupo. Entre as várias tradições trazidas do Levante pela primeira geração, os descendentes preservaram muito poucas. A língua não foi transmitida para as gerações posteriores, assim como o vestuário. Ambos dificultavam a integração à sociedade brasileira, ainda mais se tivessem que casar com não-patrícios. Mas no interior do espaço doméstico, uma tradição podia ser transmitida e preservada pelas receitas passadas para posterioridade, independente do quanto estivessem familiarizados a cultura que as originou. Não se precisava conhecer a língua árabe, nem adquirir outros costumes além do gosto por aquele alimento. Nas palavras de Carvalho (2002:83), também uma descendente de sírio-libaneses, a culinária é apresentada como "cartão de visita da origem”, algo que mantém e autentifica a identificação com uma ancestralidade comum deste grupo.

\subsubsection{Muçulmanos}

No caso da imigração muçulmana, é possível dizer que ainda se encontra numa segunda fase migratória, existindo ainda um número significativamente maior de homens que mulheres. No casamento e na formação de relações de família as duas imigrações se distinguem em matéria de integração, permanência e continuidade da comunidade estabelecida no Novo Mundo (excetuando o caso da colônia Sírio-Libanesa de São Paulo). Os frequentes casamentos arranjados encontrados entre os árabes muçulmanos demonstram a continuidade das relações de parentesco e identidade com a terra de origem e também com o constante ir e vir dos árabes muçulmanos que frequentemente retornam para o país de origem, mesmo que seja para visitar e conhecer os parentes. Essas viagens não são meras excursões de turismo baratas, elas demandam muitos recursos e apoio financeiro da família através de redes de apoio que ajudam a manter os vínculos com a terra natal. Embora não haja apoio do governo ou de empresas de migração o apoio familiar estabelece uma base relativamente sólida e segura e por sua vez as famílias no Brasil financiam seus parentes no exterior.

Os árabes muçulmanos que vieram e vem para o Brasil raramente se aventuram totalmente isolados e dispersos no desconhecido, sem qualquer apoio ou financiamento familiar. São poucos os que não vieram para onde havia um irmão ou primo morando. Tratase de um tipo de família extensiva transnacional e em que os laços de apoio se verificam também no retorno aos países de origem, aonde as famílias de lá acomodam visitantes, jovens que vão morar um tempo para estudar ou simplesmente para arranjar esposas, já que tradicionalmente as mulheres não devem viajar desacompanhadas do esposo ou de algum 
parente do sexo masculino. A intenção é claramente fortalecer a tradição e a identidade do grupo assegurando uma continuidade dos costumes e da cultura de origem nas novas gerações. Viajar ou morar temporariamente no país de onde vieram seus ancestrais para a segunda e mesmo para a terceira geração é uma forma de manter os laços familiares e a tradição, mesmo longe, num novo país com costumes tão diversos. E aí está uma das diferenças mais marcante entre os primeiros imigrantes da década de 10 e 20 e esses novos: o Brasil se apresenta como um país estranho não apenas pela língua, pelo clima e pela paisagem, mas pela sua religião e pelos costumes culturais ocidentais.

Um traço distinto entre os árabes vindos antes da segunda guerra mundial e após a segunda guerra mundial é a religião. Tirando fatores como a comida, o traje e o idioma, comuns para estes novos imigrantes como outrora fora para os primeiros imigrantes, a religião é o que mais distingue a identidade dos novos imigrantes e o estranhamento com o novo país. Enquanto aqueles eram cristãos, com não muito estranhamento das práticas religiosas desempenhadas pela Igreja no Brasil, estes já são muçulmanos e não possuem este vínculo que cruza fronteiras, línguas, sociedades e culturas. Estando neste sentido isolados e sem esses contatos com a nova sociedade, alguns árabes muçulmanos de Florianópolis se apegam ainda mais a religião, que une sua tradição, sua herança e sua identidade, e também as fortalecem através dela. $\mathrm{O}$ ir e vir ao país de origem, e também a endogamia, tem entre seus objetivos preservar os costumes ligados à religião islâmica, que fazem parte integral da tradição da família.

Há para estes imigrantes a questão da frouxidão dos costumes e das regras morais, do Ocidente em geral e do Brasil em particular, o que também enseja movimentos de indas e vindas, um dilema entre permanecer e voltar. Há inúmeros preocupações em termos de preservação da tradição e observância de preceitos religiosos, como em relação ao jejum, vestimenta apropriada e o consumo de álcool, dentro da sociedade brasileira. As dificuldades apresentam-se sobretudo entre as gerações, já que os jovens são formados dentro de uma cultura midiática globalizante, um sociedade com ativa participação feminina no mercado de trabalho, o contato nas escolas com não-muçulmanos (em maioria), a erotização da sociedade e aumento das relações conjugais, ruptura de isolamento proporcionada pela televisão e pela internet, aumento de casamentos mistos; tudo isto sendo considerados como base para degradação moral, minando os valores e modo de vida muçulmano.

Essa reconstrução da vida é a situação comum para estes imigrantes árabes de um modo geral, tanto para libaneses como para palestinos. Esta experiência no Brasil certamente serve para aproximá-los como árabes. Antes de tudo, o contexto de uma imigração 
propriamente urbana, baseada no comércio que casualmente convergiu famílias que buscavam oportunidades econômicas ou uma melhor qualidade de vida. Ambos enfrentaram basicamente as mesmas dificuldades lingüísticas e culturais, aonde as diferenças internas do mundo árabe quase desaparecem perante a estranheza com nova realidade. Sem dúvida, foi esta a situação que os uniu em solo brasileiro como uma comunidade. É neste contexto que o "processo de arabização" identificado por Espinola se verifica, ou seja, essa afirmação cultural em que "o termo árabe, mesmo que genérico, tem sido acolhido pela comunidade, que encontra nesta definição uma forma de mostrar-se como coletividade, remetendo a uma origem e religião comum" (Espinola: 2005, 219). Todos partilham de uma língua comum, de costumes comuns e da religião islâmica em comum, excetuando alguns poucos cristãos que fazem parte desta onda migratória árabe do pós-guerra. A continuidade das tradições e da etnia tem haver com manter-se árabe. Mesmo assim, em Florianópolis "não há casamentos mistos, entre palestinos e libaneses". Aqui entramos no campo da identidade, aonde ser palestino é uma distinção tão importante quanto ser árabe. 


\section{Entre a Palestina e o Brasil: a trajetória migratória dos palestinos em Santa Catarina}

Embora as razões da emigração e trajetória migratória dos árabes no Oriente Médio apresentem elementos comuns a vários fluxos migratórios contemporâneos que tendem a ser a procura de melhores condições socioeconômicas e/ou simples evasão de um país em guerra, não obstante, há muitas particularidades que marcam sejam a experiência individual ou coletiva. O desenraizamento, o exílio e refúgio, ou seja, formas não-voluntárias de deslocamento, freqüentemente surge na narrativa de vida desses imigrantes, mesmo quando não sejam eles próprios que tenham os experienciado. Mesmo aqueles que não passaram diretamente por essas experiências normalmente tem algum parente próximo que as viveu pessoalmente.

\subsection{Diáspora palestina}

Em 1947, a população palestinava somava 1.303.585, dos quais 70\% viviam em áreas rurais. Trinta e quatro anos depois, esta população somava quatro milhões e meio de pessoas, $60 \%$ da qual (2,6 milhões) vivia fora dos territórios da Palestina do Mandato Britânico (Smith, 1986: 91). Em 1995, apenas 40\% dos palestinos residiam na Palestina histórica. A maioria estava dispersa como refugiados nos países mais próximos ao redor, isto é, Jordânia, Líbano e Síria. Esse êxodo maciço tem início com a Nakba, quando em 1948, o recém-criado Estado de Israel forçou entre 700 mil a um milhão de palestinos a tornarem-se refugiados, destruindo 531 vilas palestinas no processo, além de provocar o êxodo maciço de 11 cidades majoritariamente palestinas (Pappe, 2006: 82). Do território contínuo da Palestina restou apenas a Cisjordânia, anexada pelo Reino Hachemita da Transjordânia e formando a Jordânia, e a Faixa de Gaza, que ficou sob controle egípcio, embora não tenha sido formalmente anexada.

Além da Nakba, que levou ao primeiro êxodo de cerca de 800 mil palestinos do território que seria o futuro Estado de Israel, os fatores que impeliram o êxodo palestino PósNakba foram tanto econômicos quanto políticos. Com maiores investimentos favorecendo a margem oriental do Rio Jordão na Jordânia, muitos palestinos da Cisjordânia foram encorajados a mudarem-se para lá nas décadas de 1950 - 1960 (Farsoun, 1997 :138). 
Outros palestinos, devido à estagnação econômica tanto da Cisjordânia quanto de Gaza, migraram para países árabes exportadores de petróleo, que necessitavam de mão de obra de diversos tipos (com e sem instrução). Outros migraram para o Líbano na década de 1960, devido à prosperidade gerada indiretamente por conta do boom do petróleo na região. Assim, a porcentagem de palestinos em seu território histórico diminui de $80 \%$ logo após a Nakba, para 63 por cento pouco antes da guerra de junho de 1967. Em decorrência dessa guerra, essa porcentagem caiu de 63 por cento para 50 por cento, devido ao êxodo de 400 mil palestinos da Cisjordânia e de Gaza. Isso significou uma diminuição em 12\% na Cisjordânia de uma fatia de $34 \%$ de todos palestinos antes de junho de 1967, para $22 \%$ no final daquele ano (Ibidem: 138-139).

Embora os números de refugiados, devido ao seu status especial, seja muito preciso, o contrário deve ser dito em relação ao palestino imigrante. Estima-se que em 1995 havia 200 mil palestinos residindo nos EUA e no Canadá e um número similar no resto do Hemisfério Ocidental (Ibidem: 139). No relatório intitulado Survey of Palestinian Refugees and Internally Displaced Persons 2008-2009 do Centro de Recursos Badil para direitos de residência e refúgio de palestinos (Badil, Dezembro 2009: 63), a população de Palestinos nas Américas aparece registrada em apenas três países: Canadá, EUA e Chile. Os dados variam de aproximadamente 43-52 mil para o primeiro e 225-261 para o segundo. No Chile, são identificados mais de 325 mil, embora não estejam claros os critérios, nem os métodos para se alcançar tal número. Não há também uma clara distinção entre refugiados e imigrantes. Abdel Ibrahim Muhammad, um imigrante palestino residente em Tubarão, estima que existam no Brasil entre 50 a 60 mil palestinos e descendentes.

\section{2 Êxodo da Palestina}

A imigração palestina para o Brasil é um fenômeno recente, originando-se na década de 1950 por motivos socioeconômicos e político-religiosos semelhantes ao de sírios e libaneses anteriormente. Na palestina isso ocorre desde o momento em que as estruturas sociais anteriores começa sofrer alterações pela execução do projeto sionista desde fins do século XIX e do colonialismo britânico a partir de 1918, culminando na criação do Estado de Israel, o que levou a uma significativa mudança na estrutura socioeconômica e política da região, levando ao êxodo da Palestina centena de milhares como refugiados e mais alguns tantos para o exterior mais distante em busca de melhores condições de vida. 
A imigração palestina para o Brasil começa propriamente na segunda metade do século XX, embora já existisse um pequeno fluxo anterior. Sua quantificação é difícil, especialmente pela inexistência de um Estado próprio e a utilização de passaportes jordanianos (Hamid, 2007: 53). A vinda dos palestinos a partir da década de 1950, como apontam os relatos, está relacionada em grande medida a problemas econômicos e políticos da região, cuja criação do Estado de Israel realçava.

Causas de ordem econômica para emigração encontram-se em praticamente em todas as sociedades do mundo globalizado contemporâneo. As dificuldades financeiras e a falta de oportunidade podem variar muito, principalmente entre os países subdesenvolvidos, que estão em diferentes estágios de adequação e inadequação à economia de mercado. Apesar disso não significa que nas causas econômicos não seja possível considerar um forte elemento de coerção. Segundo Dowty (1986: 156), a emigração do Terceiro Mundo frequentemente é forçada, seja diretamente ou indiretamente, através de uma série de medidas ou condições sociais (como a discriminação) que por fim se adéquam aos propósitos de um governo. Toda uma série de fatores políticos, sociais, econômicos que acabam levando ao êxodo populacional podem ou não estar diretamente relacionados a governos, mas nem por isso deixam de implicar sua responsabilidade. Fatores que levam a saída frequentemente podem estar relacionados a ações governamentais em nome do desenvolvimento e da modernização, levando tanto a mudanças socioeconômicas, quanto a supressão de modos de vida tradicionais.

Aqui cabe uma diferença fundamental entre os outros dois países de onde provém maior parte dos imigrantes árabes, Síria e o Líbano, países independentes e com relativa liberdade e controle sobre sua economia. Já Palestina foi um território inicialmente sob um regime de mandato que favorecia outro povo (imigrantes judeus), depois fragmentado, com maior parte de sua população dispersa (Nakba) e atualmente ocupado e com os serviços governamentais mais básicos controlados por um país estrangeiro.

Patente nas narrativas dos imigrantes palestinos está a constação de Farsoun, (1997: 135) de que "os eventos de 1948 e 1967 deixaram uma marca indelével na memória coletiva dos palestinos".

Entre os colaboradores palestinos, pode-se identificar uma série de fatores que os levaram a deixarem suas terras:

Pré-1967

- Fragmentação do território e despovoamento:

- Dissolução das redes espaciais de interação econômica 
- Bloqueio à educação

- Reestruturação político-econômica

- Perseguições políticas (repressão de dissidentes pelo governo jordaniano)

\section{Pós-1967}

- Destruição de vilas

- Caso de 'Imwas, Yalu e Bayt Nuba em 1967

- Confisco de propriedades (Parte do caso mencionado acima)

- Restrições à mobilidade

- Postos de Controle

- Barreiras

- Expulsão/Deportação

- Confisco de propriedades

- Demais restrições a liberdades civis e políticas:

- Detenções administrativas, dificuldade de acesso à saúde e educação, entre outras.

A vida de muitos palestinos de Santa Catarina em sua terra natal foi desde cedo marcada direta ou indiretamente pela $N a k b a$, pelo trauma da fragmentação deste país. O problema palestino apareceu como um marco na infância entre todos os entrevistados. Em sua tenra infância, Khader Othman, palestino residente em Florianópolis nascido em Bayt urTahat em 1939, presenciou a Nakba o êxodo dos palestinos dos territórios conquistados por Israel em 1948, evento que ficou fortemente registrado em sua memória, apesar de passados 60 anos do ocorrido, como ele mesmo colocou:

[...] a coisa que até agora mais esta viva na minha memória, depois sessenta anos, está bem viva, são aqueles momentos em que eu vi, quando eu estava com praticamente nove anos, os palestinos se refugiando, sendo expulsos da sua pátria, de suas terras e de suas casas e passando pelo povoado onde nós morávamos. Alguns ficavam lá conosco naquele povoado ali e nós e os nossos pais oferecíamos comida, água e o pessoal depois ou ficava lá ou continuava para o destino final [...]

O Abdul Oda, palestino residente em Criciúma desde 1962, apresenta um trajetória de um imigrante árabe característico, exceto no que se refere à causa de sua emigração. Como vivia em Jerusalém e era estudante secundarista na época da guerra de 1948, teve que abandonar os estudos devido às restrições de mobilidade da guerra e depois da anexação de Jerusalém Ocidental pelo Estado de Israel: 
Eu nasci em 1933 em Jerusalém. Fiz o quarto ano (da escola) na minha aldeia, Anata. Depois comecei na cidade de Jerusalém. Aí começou a guerra em 1948 entre árabes e judeus. A gente não podia ir para Jerusalém para estudar.

A fragmentação e perda de coesão social teve efeito direto em sua trajetória de vida, já que morava e estudava em uma cidade que ficou divida entre a Jordânia e Israel na guerra de 1948:

Eu saí em 1953. Não tinha estudo. Não tinha trabalho. E não tinha isso, porque ao invés da Inglaterra sair de lá, a Palestina foi divida em duas partes: $52 \%$ para o Estado de Israel e $48 \%$ para o Estado Palestino. Naquele tempo tinha só sete países árabes independentes nas nações Unidas que não aceitaram a partilha e assim começou a guerra com os três países que fazem fronteira com Israel: Jordânia, Síria e Egito. A nossa parte da Palestina, do Estado Palestino, foi anexada pelo Estado da Jordânia. Nós ficamos jordanianos. Aí a mesma coisa. Os jordanianos também não nos respeitavam. Nós dizemos que preferíamos sair de lá.

Abdel Ibrahim Muhammad, palestino residente em Tubarão desde 1960, informa que a razão de ter emigrado, assim como outros conterrâneos seus, é que "não tinha trabalho nenhum, porque antes de acontecer aquilo lá na Palestina (a Guerra de 1948) estava bem”. Kimmerling \& migdal (129-130) mostram que a depressão econômica no país com o início da Segunda Guerra Mundial (por exemplo: queda de salários, exportações e encerramento da exportação de frutas cítricas em 1943) foi contrabalanceada pela mobilização de tropas e seu arregimentação na Palestina, mudando radicalmente a situação. A economia da parte árabe da Palestina crescia a 9\% ao ano de 1940 a 1945. Naquele momento, a Palestina ultrapassava todos os outros países árabes vizinhos em quase todos os indicadores econômicos. A mobilização significou um aumento de 400 por cento do investimento militar britânico ali, gasto sobretudo no setor de construção. O número de tropas estacionadas cresceu de noventa mil para 280 mil, gerando a necessidade de abastecimento de tropas com alimentos, de trabalho para construir barracas e estradas, assim como para produzir armas e munição. Para atrair os camponeses em um período de elevação dos preços dos produtos agrícolas, começouse oferecer salários mais altos, o que aumentou enormemente o fluxo de trabalhadores do campo para cidade, além de permitir um aumento nos padrões de vida considerável no campo. Estimulando e contribuindo com este processo estava o apoio dado pelo governo britânico para o aumento da produção para o abastecimento de tropas durante a guerra, de forma que a produção agrícola cresceu $20 \%$ durante este período. Sem dúvida, a ruptura com esse modo de vida provocado pela retirada britânica e pela Nakba está no cerne do problema econômico que levou a emigração da Palestina. 
Adib Ahmad, palestino residente em Florianópolis, com conta que seu pai foi indiretamente afetado pela fragmentação da Palestina, já que seu trabalho envolvia a transumância por diversas vilas que deixaram de existir após a Nakba. Antes mesmo dele nascer em dezembro de 1963, Adib conta que seu pai já havia deixado a Palestina "pela pressão que tinha sobre os jovens naquela época e pela vontade de vir embora mesmo, porque a situação estava difícil”. Seu pai era apicultor e costumava cruzar o país disseminando as abelhas que trazia em umas caixas por várias regiões antes da divisão em 1948. A partir daí, não foi mais possível. Então voltou-se para o negócio de sua família, processamento de azeitona. Um combate aos produtos palestinos acabou malogrando sua atividade de trabalho e ele resolveu vir para o Brasil:

Meu pai naquela época era apicultor e ele cruzava muito (a região). Antes da divisão de 1948 de toda aquela região era Palestina, ele pegava e botava as abelhas em uma determinada região. Logo depois da fundação do Estado de Israel, isso não era mais possível. A minha família tinha um negócio de processar azeitonas que se chamava faraza, onde meu pai trabalhava. Um combate aos produtos palestinos acabou numa situação muito difícil deles viverem e (ele) acabou indo embora para o Brasil.

Para Khader Othman, irmão do pai de Adib, a infância foi mais curta e logo teve de trabalhar, pois seu pai havia morrido cedo e teve de assumir as responsabilidades da família. Como filho mais velho ainda presente, os outros tinham migrado ou serviam no exército, era seu papel sustentar sua família, sua mãe, seus irmãos mais novos. Tentou abrir uma lojinha, mas não deu certo. Então arranjou um emprego como funcionário público para o governo da Jordânia em Amã, há cento e cinquenta quilômetros de onde sua família morava, uma distância considerável na região do Levante. De lá "voltava uma vez por mês para casa e o que sobrava, deixava para mãe fazer o gasto do mês seguinte para família”. Enquanto trabalhava na estatística do governo da Jordânia, testemunhou eventos que fizeram com que se aliasse a um partido de oposição ao governo:

Eu comecei a trabalhar cedo. Eu tive uma lojinha pequenina ali, naquela época, não deu certo e eu trabalhei dos anos 1959 a 1963 na estatística do governo da Jordânia. (...) fiquei até os 1964 como funcionário público, vendo as barbáries que acontecia ali contra o povo, a má distribuição de renda e a grande corrupção. Eu optei por um partido político lá, (já que) a época era revolucionária. Mas antes de fazer qualquer coisa nós já estávamos presos. A inteligência da Jordânia era extraordinária, porque ele (o Rei) esperava ser derrubado de qualquer forma devido às tantas barbáries que fazia. Então, fiquei preso ali até os 1966. Quando saí, meu irmão estava aqui no Brasil, em Tubarão e eu escrevi pra ele expondo as coisas como estavam ali, 
reclamando da situação econômica e tudo mais. Ele ofereceu que eu visse para cá, se quisesse. Eu não tinha outro caminho e achava que esta aqui poderia ser uma saída tanto para mim quanto para família. Concordei e vim.

O segundo acontecimento mais marcante na história da Palestina moderna é a Ocupação dos territórios da Cisjordânia e Faixa de Gaza. Em resposta a uma mobilização de tropas egípcias próximo de sua fronteira, Israel lançou um ataque contra o Egito e invadiu e ocupou os territórios da Jordânia a oeste do Jordão, a Cisjordânia, assim como as Colinas de Golan da Síria e o Sinai no Egito. Tudo ocorreu em mais ou menos seis dias, como o nome Guerra dos Seis Dias indica, e no final Israel havia quadruplicado seus territórios. Além disso, este Estado agora adicionava uma população de mais de um milhão de palestinos dentro de seus territórios, além de provocar um número semelhante de refugiados dispersos em outros países árabes, principalmente na Jordânia.

Como nota Hamid (2007: 53), a referência a Israel é muito marcante na construção do discurso identidatário dos imigrantes palestinos, sobretudo aqueles vindo após a guerra de 1967. Quando Israel invadiu a região da Cisjordânia em 1967, alguns dos palestinos entrevistados que lá viviam na época experienciaram direta ou indiretamente alguns dos medidas mais drásticas da ofensiva israelense. Embora muitos tenham vindo sem experimentar uma forma direta de expulsão e desenraizamento, há algumas notáveis exceções entre alguns palestinos de Santa Catarina. Para Mahmoud Hussein, palestino residente em Florianópolis nascido em 1953, quando ainda era jovem, a emigração surgiu em decorrência do desapossamento total após sua cidade natal ser destruída por completa. Em 1967 três cidades na fronteira de Israel com a Cisjordânia sofreram limpeza étnica e demolição de todos os edifícios,como ele constatou:

Eu na época tinha nove ou dez anos de idade, mas como não podia voltar, não podia habitar (mais), porque aquelas três cidades foram tomadas e não permitiram a volta de ninguém: Yalu, Bayt Nuba, 'Imwas, três cidades.

Em 1967, essas três vilas foram destruídas pelo exército israelense e mais de dez mil pessoas foram forçadamente deslocadas por conta disso (Reynolds, 2007: 9). Ao invés de simplesmente mudar-se para um campo de refugiados, como ocorreu com tantos palestinos que fugiram ou foram em 1967, Mahmoud Hussein teve sua tragédia mitigada pela imigração já realizada pelo pai. Estando seu pai já instalado no Brasil, pode ser trazido junto com o resto de sua família (sua mãe e seus irmãos), para onde morava, após um curto período de residência na Jordânia, entre um a dois anos, quando "o pai veio aqui, se ajeitou e depois a gente veio (para o Brasil)". 
Mais peculiar ainda é o caso do Mohammad Mahasan, palestino residente em Lages, que quando ainda tinha poucos anos de vida foi expulso com sua família de Jaffa para Gaza, onde viveu como refugiado, dependendo dos subsídios da ONU:

\begin{abstract}
Eu lembro que quando eu nasci em 1944, os judeus foram entrando na Palestina para mandar todos palestinos embora. Em 1948 foram mandados todos palestinos embora. A minha família foi para Faixa de Gaza. Eu vivi numa barraca praticamente até dia que eu vim para cá em 1970. Todo mundo lá, os palestinos, dependem de ajuda da ONU para comer, beber e dormir, porque não tem nada. Um país que não tem nada. Não tem, indústria e outras coisas. E naquela época da guerra, a faixa de Gaza pertencia ao Egito e a Cisjordânia pertencia à Jordânia.
\end{abstract}

Já adulto, teve sua trajetória alterada diretamente por ações israelenses. Mohammad Mahasan é o caso único entre os imigrantes estudados de alguém que foi diretamente expulso da Palestina para América do Sul. A deportação de palestinos dos Territórios Ocupados sem processo formal foi instituída oficial pelas autoridades militares israelenses em Gaza pela Ordem Militar 290 de 1969 (Hiltermann, 1986: 4). No ano 1970, 406 palestinos foram registrados como tendo sido deportados territórios ocupados por Israel. Mohammad é possivelmente um deles:

(...) depois de 67, os judeus praticamente pegaram toda Palestina. Em 1970 eu vim para cá, expulso de lá pelos judeus. Eu fui mandado para o Paraguai. Paraguai não tinha nada, nem para comer. E de lá, eu vim para cá. Que eles diziam para nós, lá no Paraguai, que não tem oportunidades de trabalho. Não tem economia, não tem nada. Aí eu vim para o Brasil e comecei minha vida. (...) Eu fui expulso, eles deram passagem, não? Eu não paguei nada(...) não tinha passaporte, nem dinheiro. Então, eles deram para mim laissez passer. E eu tava naquela época preso numa solitária e eles acharam que eu ia bem e me mandaram embora de lá. Me levaram no aeroporto, me botaram no avião e nós chegamos até aqui no Paraguai.

Ao entrar em detalhes, Mohammad revela que não foi o único palestino deportado para o Paraguai:

Interessante no Paraguai, quando eu entrei lá, eu tava com mais ou menos três ou quatro, mas nem passamos pelo polícia. Me levaram para o outro lado e saímos. No mesmo dia, de madrugada, me levaram para polícia lá, fecharam a gente e deram uma identidade que vale dez anos.

Para o Abid Al Basha, nascido em Nablus no ano de 1965 e residente hoje em Florianópolis, a vinda para o Brasil se fez a partir da diáspora nos países árabes, de uma vida onde já nos primeiros anos de vida tornou-se refugiado na Jordânia devido a ocupação israelense de 1967, quando seus pais fugiram temendo que o pior acontecesse. Após se formar na faculdade foi trabalhar no Kuwait, mas logo veio a Guerra do Golfo, o que significou novamente sua partida: 
Eu cresci na Jordânia. Até terminei a faculdade lá. Eu estudei educação física até a idade de 21 anos. Eu, graças a Deus, terminei a faculdade mais cedo e consegui sair da Jordânia para ir para outro país para trabalhar ou estudar mais. Eu queria fazer mestrado e fui para Alemanha. Depois voltei para Jordânia e fui trabalhar no Kuwait. Depois da invasão do Kuwait no ano de 1990, fui para o Iraque. Fiquei um mês no Iraque, depois voltei para Jordânia. No final do ano de 1990, maio ou junho, eu vim para o Brasil. Eu tinha um amigo meu aqui no Brasil que me falou que tem trabalho bom. Eu tinha juntado uns dinheirinhos e vim aqui para o Brasil para procurar minha vida melhor.

Nascido em 1968, Munif Omar, hoje residente em Criciúma, viveu desde o início em uma Palestina sob ocupação militar israelense:

(...) na Palestina... na verdade, a gente nunca teve infância, porque, desde que a gente nasce, vai crescendo e convivendo com o problema da ocupação na Palestina. Então, a gente não tinha infância como as outras crianças no mundo. A gente não tinha lugares para brincar. Não tinha lugares específicos para passar algum tempo depois da aula, em casa ou nas ruas. A gente brincava um pouquinho de futebol ou basquete, alguma coisa assim. Mas a maioria das brincadeiras nossas era sempre soldados judeus e palestinos, uns fugindo dos outros. Aquela é a brincadeira da vida real que a gente vivia dia a dia. A gente tava vendo dia a dia o que tava acontecendo com o nosso povo. E aquilo ali era para nós, quando éramos criança, a nossa brincadeira.

Fortemente marcadas em sua memória estão às dificuldades criadas pela ocupação a

livre movimentação e o direito de estudo dos palestinos. Ele descreve em detalhe o truncado trajeto diário até sua escola em Nablus devido aos postos de controle militares:

Até mesmo quando eu viajava de Salfit para Nablus, que é uma distância de vinte seis ou vinte sete quilômetros, a gente passava no caminho por obstáculos de verdade. Em uma distância de vinte e seis quilômetros tinha três pontos de soldados no caminho, e cada vez que eu chegava num ponto desses, você tem que parar, as vezes você tá num ônibus, desce todo mundo, mostra a identidade, explica aonde é que tu vai, tu vai fazer o quê, que horas tu vai voltar. Às vezes eles pegavam e abriam os livros para ver se tinha algo político ou alguma coisa contra Israel, etc. Então, em uma viagem de vinte e seis quilômetros que se faz no máximo em vinte minutos, levava para a gente duas horas. Eu pegava o ônibus às seis horas da manhã para chegar em Nablus mais ou menos quinze paras oito, por causa de três pontos de soldados israelenses. E na volta a mesma coisa. A gente saía de lá às duas horas da tarde ou duas e meia e chegava em Salfit, quatro e meia ou quinze para as cinco, depende, por que, às vezes, tinha muitos carros na frente.

Eu estudava no começo dentro da minha cidade, em Salfit mesmo. Depois decidi fazer escola técnica e fui estudar em Nablus na escola técnica (de lá). Isso foi nos últimos três anos (da escola), que é como o terceiro grau aqui. E nunca houve sossego, porque primeiro, a aula iria começar daqui a um mês ou dois meses, mas Israel mandava fechar (a escola). Aconteceu um problema não sei onde: "manda fechar". Então, de oito ou nove meses de estudo, a gente aproveitada no máximo seis meses às vezes. E o resto era só enrolação. Com todas essas dificuldades, a gente sempre tentou estudar e melhorar a vida. Até mesmo quando eu viajava de Salfit para Nablus, que é uma distância de vinte seis ou vinte sete quilômetros, a gente passava no caminho por obstáculos de verdade. Em uma distância de vinte e seis quilômetros tinha três pontos de soldados no caminho, e cada vez que eu chegava num ponto desses, você tem que parar, as vezes você tá num ônibus, desce todo mundo, mostra a identidade, explica aonde é que tu vai, tu vai fazer o quê, que horas tu vai voltar. Às vezes eles pegavam e abriam os livros para ver se tinha algo 
político ou alguma coisa contra Israel, etc. Então, em uma viagem de vinte e seis quilômetros que se faz no máximo em vinte minutos, levava para a gente duas horas. Eu pegava o ônibus às seis horas da manhã para chegar em Nablus mais ou menos quinze paras oito, por causa de três pontos de soldados israelenses. E na volta a mesma coisa. A gente saía de lá às duas horas da tarde ou duas e meia e chegava em Salfit, quatro e meia ou quinze para as cinco (...).

As limitações a continuação de seus estudos cuja responsabilidade sobrecai sobretudo à ocupação israelense. Esse conjunto de fatores foi o que por fim provocou sua imigração para o Brasil:

Depois que eu terminei o segundo grau, fui fazer faculdade numa ilha que se chama Chipre. E depois de três anos de estudo, infelizmente meu pai não podia mais continuar pagando a faculdade. É quando eu tive que parar. Tentei por outros lugares alguma bolsa de estudo para conseguir completar meus estudos e, infelizmente, não consegui. Aí, eu vim para cá.

Depois que eu terminei o segundo grau, fui fazer faculdade numa ilha que se chama Chipre. E depois de três anos de estudo, infelizmente meu pai não podia mais continuar pagando a faculdade. É quando eu tive que parar. Tentei por outros lugares alguma bolsa de estudo pra conseguir completar meus estudos e, infelizmente, não consegui. Aí, eu vim para cá. Não era a primeira vez que eu vinha. Já tinha visitado o Brasil em 86. Eu tenho um tio meu aqui que me convidou pra visitar o Brasil. Claro, nunca tinha saído da Palestina, nunca sonhei em sair dali. Até sonhar, a gente sonha, mas achava que era difícil ou impossível pelas dificuldades israelenses. Eu consegui fazer uma visita ao Brasil em 86 e eu amei o lugar. Eu achei que tinha muito trabalho. Tinha comércio excelente na época. Me apaixonei pelo Brasil. Só que o pai mandou eu voltar pra completar meus estudos. Então, voltei pra estudar. Daí, infelizmente, não deu pra completar e parei de estudar. Não deu mais tempo de completar os estudos. A única opção que sobrou pra mim era voltar pra cá pra trabalhar.

Como muitos dos imigrantes de primeira geração, Munif Omar teve um parente que o recebeu. A pergunta que naturalmente surge disso é quem foram os primeiros e porque vieram ao Brasil especificamente? A vinda dos primeiros imigrantes para o Brasil é difícil ser rastreada com precisão, mas sem dúvida está ligada ao fluxo de imigração anterior, que teria sido responsável pelos rumores sobre o Brasil relembrados por Abdul Oda: "Nós recebíamos notícias lá de que o Brasil era um país bom. Então, fomos para o Brasil.” E também por Adib Ahmad, pelo que foi lhe foi contato por seu pai:

Meu pai nunca tinha vindo para o Brasil. Meu avô já tinha viajado antes disso para o Havaí, isso em 1920, por aí, um pouco mais, um pouco menos. As pessoas de mais idade contam isso. E ele veio do Havaí, voltou para Palestina, voltou bem. E o pai (eu) acho que ficou com aquele espírito, vou sair, vou ganhar dinheiro, vou viver fora e acabou vindo. Mas relação direta nós não tínhamos. Escutávamos dizer sobre o Brasil que naquela época aceitava os imigrantes, aceitava pessoas de fora e eles vieram para o Brasil, vieram trabalhar, ser mascate.

\subsection{Inserção econômica}


O início da imigração para o Brasil costuma a remeter nas narrativas a alguma figura pioneira que deixou a terra natal por conta própria em busca de melhores condições econômicas no exterior ${ }^{9}$. Aqueles que eram casados deixavam sua mulher e seus filhos e vinham sozinhos. Quando chegavam ao Brasil desempenhavam principalmente atividades comerciais, mais especificamente o mascatear.

De fato, a função de mascate era ainda oportuna ou necessária em certas áreas sem um grau significativo de urbanização ${ }^{10}$. Como esta atividade apresentava menos requisitos para entrada, fossem em termos burocráticos ou em termos linguísticos, esses imigrantes a viam como o melhor ou único recurso temporário para iniciação na nova sociedade. Além desta função propedêutica, a possibilidade de uma acumulação rápida de dinheiro sem a necessidade de um grande investimento inicial de capital alimentava as esperanças de enriquecimento fácil e imediato. A realidade dificilmente se revelou tão alentadora. A relativa flexibilidade dessa atividade estava condicionada aos esforços necessários para percorrer e viajar por diversas cidades e pelo interior dessas. No entanto, acompanhando a urbanização que se seguiu no Brasil a partir das décadas de 50 e 60, aqueles pioneiros acabaram abandonando a posição de mascate pela de comerciante urbano tão cedo quanto conseguiam acumular capital suficiente.

A opção pelo comércio foi preponderante entre eles: “O comércio, sempre trabalhou no comércio. No início ele desconhece a língua, não tem muito conhecimento, então foi no braço, só assim mascateando, carregando mala nas costas para lá e para cá até que formou a vida" assim falou o Mahmoud Hussein a respeito do trabalho que seu pai exerceu. Como constatou Espinola (2005:10) em Florianópolis, o que é possível estender ao resto do Estado, o comércio foi e ainda é a atividade de trabalho preponderante entre os imigrantes árabes de que vieram após os anos 50. Por ser uma migração recente e em muitos casos ainda em processo, a preferência pelo comércio surge devido às facilidades para adaptação e aprendizado da língua que o convívio do dia-a-dia no mercado ou na lojinha oferece. Há aí verdadeiras similaridades no que concerne às atividades de trabalhos com a trajetória dos imigrantes sírio-libaneses aparecem entre os pioneiros, que chegaram numa época em que o interior do Brasil ainda oferecia oportunidades para mascatear. Aí se verificou as maiores dificuldades na adaptação e construção da vida no Brasil:

\footnotetext{
${ }^{9}$ Como mostra Jardim, é difícil identificar asseguradamente um pioneiro, pois atrás da história de um imigrante há normalmente um contínuo de histórias que o precederam. (JARDIM, 2007: 218)

${ }^{10}$ Jardim verifica isso no caso do Chuí, "que pode ser entendido como uma fronteira de expansão dos mascates". (Jardim, 2000: 186)
} 
As dificuldades eram grandes. Porque na época, ele marcou bem que as pessoas moravam mais no sítio. Então, eles não vendiam dentro da cidade, mas vendiam mais no sítio. Eles tiveram muita dificuldade. Às vezes passavam três ou quatro horas para ir de uma cidade à outra de carona ou de charrete ou de a pé ou de ônibus, sei lá. Tinha muita dificuldade. Quando chovia era muito lama. Mas as pessoas de um modo geral acabavam até comprando deles de pena. Por exemplo, às vezes viajavam o dia todo, quando davam a sorte de chegar numa casa antes do anoitecer acabavam pedindo para acabar dormir lá. As pessoas às vezes deixavam (dormir), as outras vezes não deixavam. Mas de um modo geral tinham. Mas era muita dificuldade. Tinham duas malas, uma de um lado, uma de outro, e aí andavam kilômetros e cidades. O meu pai trabalhou no Rio (Grande) do Sul, trabalhou em Porto Alegre. Logo em seguida veio a Tubarão e ficou. Já em Tubarão estabeleceuse com lojas. Mas a dificuldade era muito grande.

O relato de Abdul Oda sobre sua experiência pessoal como mascate apresenta elementos comuns à descrição feita por Adib sobre seu pai, tanto no que se refere à intrepidez do mascate que se aventurava pelas

Não foi fácil o trabalho nas colônias, nas fazendas. Foi de a gente chegar a passar
fome. De a gente chegar a dormir no meio de café. Não foi fácil não. Mas, não existe
povo igual o povo brasileiro. Eles chegavam à noite, batiam na porta, abria a porta
para nós, arrumava a cama, arrumava a janta.

Mesmo entre esses "pioneiros", que haviam chegado sem um parente próximo para lhes prestar auxílio, a inserção no novo ambiente era viabilizada pelo papel desempenhado na ajuda aos recém-chegados pelas redes de contatos com patrícios. Por meio delas era possível obter algum apoio material inicial, a regulamentação de documentos, referências de lugares para trabalhar e até ofertas de emprego ou parceria. Este círculo interno de informações servia como um mapeamento de uma série de percursos possíveis para estruturação da vida econômica no Brasil, podendo levar esses imigrantes a percorrer diversas localidades no país na procura de um espaço mais adequado para se assentar.

Abdel Muhammad apresenta-se como uma daquelas raras figuras pioneiras, cuja imigração não parece ter ligação com parentes de primeiro grau, mas como seu relato revela, com uma rede étnica árabe mais ampla:

Viemos mais ou menos 15 a 20 palestinos e ou menos 50 árabes, (com) sírios e libaneses. Chegamos aqui em Santos no dia 15 de abril de 1954. Eu tinha o endereço de um amigo meu em Pirajuí no Estado de São Paulo, perto de Bauru. Fiquei lá um ano com colegas meus. Tinha mais ou menos 20 a 30 palestinos.

Denise Fagundes Jardim registra o caso de Jundi (Jardim, 2000: 169-183), palestino hoje residente no Chuí - RS, que chegou por Santos e foi em seguida para São Paulo onde encontrou muitos patrícios. Os contatos lá adquiridos o levaram a um patrício que morava em Joaçaba - SC. Este por sua vez o sugeriu que fosse para Joinville - SC, onde havia outro 
patrício que então lhe ofereceu um emprego na loja dele. Após seis meses, voltou para Joaçaba e fez sociedade com um patrício. Anos depois de ter estabelecido sua própria loja lá, resolveu mudar-se para o Chuí.

A trajetória de Jundi reproduz o padrão São Paulo - Rio Grande do Sul (Santa Catarina aparece na ordem inversa do que para os imigrantes hoje nesse Estado). Como visto a entrada por Santos e para o interior de São Paulo dá-se por uma rede de contatos. Entretanto, as possibilidades econômicas desse Estado com uma presença árabe bem assentada, que já se tecia suas próprias redes de integração e ascensão econômica, levou muitos palestinos a buscar uma fronteira para expansão de sua atividade, especialmente da atividade de mascate.

Como já mencionado em Jardim, a fronteira Brasil-Uruguai, ao menos até o início da década de 1990, apresentava como um espaço de possibilidades. Abdel Muhammad constatou que para onde no interior de São Paulo, "todo o comércio lá já tinha mais de 50 lojas de árabes: sírios, palestinos libaneses”. Estando supersaturado/esgotadas a possibilidades de inserir-se naquele meio, os palestinos “viajaram tudo para o Rio Grande do Sul mascateando". Sua própria trajetória seguiu esse padrão:

No Rio Grande do Sul, nós vendíamos bem, porque naquele tempo só tinha estrada de terra. (...) Não tinha ônibus. (...) Vendia bem mesmo. Melhor do que a loja.

O padrão São Paulo - Rio Grande do Sul - Santa Catarina parece se reproduzir em outros relatos de imigrantes mais antigos, como no de Abdul Oda:

Eu entrei pelo Rio de Janeiro. Nós descemos de navio em Santos. Fui morar em São Paulo, na cidade de Pirajuí, onde tinha bastante árabes. Morei em Pirajuí, depois em Porto Alegre. De Porto Alegre fui para Garça, Estado de São Paulo, e depois voltei para Criciúma. Estou aqui desde 1962 em Criciúma.

Da mesma forma que as possibilidades de comércio e enriquecimento direcionaram o fluxo migratório palestinos para determinadas regiões, notavelmente a fronteira do Rio Grande do Sul com o Uruguai, o declínio econômico das mesmas levou a êxodo em grande número. Possivelmente é o caso do Oeste de Santa Catarina, que fez parte da trajetória de Jundi (Jardim, 2000: 169-183) e a respeito do qual Abdel Muhammad explica que:

Tinha no Oeste de Santa Catarina uns poucos árabes, na realidade. Tinha uns poucos palestinos em São Miguel do Oeste... Agora acho que não tem nada. Os palestinos estão aqui na faixa (costeira): Criciúma até Florianópolis. Em Joinville tem um. Em Blumenau e Itajaí não tem. Tem 5 ou 6 pessoas em Camboriú. 
Apesar de sublinhar a importância do Chuí sua inserção econômica no Brasil quando fala "Eu vim direto para fronteira com o Uruguai, Chuí. Tinha um amigo meu lá que trabalhando no ramo de supermercado. (...) Trabalhei e ganhei dinheiro bem"”, exemplifica a mobilidade da imigração palestina ao descrever sua pronta reação fato de que "caiu também o movimento lá bastante. Acabei saindo da fronteira e vim morar em Santa Catarina":

Agora se você vai para o Chuí, não acha nada, só acha uma meia dúzia de palestinos, mas também tá muito ruim de poder aquisitivo (...) ficou muito fraco o movimento lá e as pessoas que tinha mais poder aquisitivo, mais dinheiro mais e poder lá, sentiram na pele. A maioria das pessoas caíram fora.

Abid explica como não teve interesse em arriscar manter-se numa situação econômica ruim:

E eu, quando senti isso, eu rapidinho caí fora também, porque eu não vim de meu país para sofrer aqui, sinceramente. Tem gente que achava que daqui um ano melhora. Eu não posso esperar, eu não tenho condição de esperar mais tempo. Então, por isso eu saí de lá e vim para cá e comecei minha vida aqui (Florianópolis). Eu acho que há mais estabilidade aqui. Uma cidade melhor, um clima melhor. Só cresce aqui. Lá, infelizmente, não cresce, porque não tem como crescer. Ali (...) é um lugar muito esquecido no tempo. Não tem quase nada. (...)Eu vim pra Santa Catarina o ano de 1996. Vim pro Brasil em 1990 e fiquei até 95. Fui pra Jordânia e casei em 1996. Voltei com minha esposa em 1996 pra Santa Catarina mesmo. Pra Balneário Camboriú direto. Criei minha vida de novo lá com minha esposa.

Mohammad Mahasan fala como também interagiu com as possibilidades econômicas que percebeu e como isso teria levado a mudar-se para Lages:

Eu tava em Curitiba. Eu trabalhei um ano e dois meses lá no supermercado de um patrício. Aí eu saí de lá e comecei a trabalhar com a madeira. Eu nem falava português direito. Eu fui numa firma e disse "É o seguinte, eu quero comprar madeira de você". O cara deu risada. (Eu disse) "O brasileiro não sabe comprar direito madeira". (Ele disse) "Você não é que não sabe falar português". (Eu respondi) "O senhor não vai perder nada. O se o senhor me der uma cartinha, você compra, você paga". Eu trabalhei primeiro na Cevisa, lá em Curitiba. Trabalhei de 1974 a 1981. A Cevisa fechou. Aí entrei na Naribo. Trabalhei até 89. Depois eu trabalhei para mim mesmo. Até chegar o real, tava bom, maravilhoso. Quando chegou o real, a madeira era noventa dólares e pulou para cento e quarenta dólares. Então, acabou a madeireira.

Após esses primeiros aventureiros, vieram outros imigrantes a sós, como é o caso do Khader Othman que veio para aonde estava seu irmão. Estes eram homens adultos, que também vinham para constituir suas próprias vidas, mas com o auxílio local de um parente. Diferentes daqueles pioneiros que dificilmente conseguiram apelar em socorro para um familiar, estes tinham um esteio para começar a nova vida, que desde o começo ofereciam moradia e alimentação como também um emprego e ajuda financeira. Também o conhecimento da língua e dos costumes era facilitado pela presença de um familiar disposto. 
Este apoio era obviamente limitado ao que se podia dispor, o que não foi diferente em relação à atividade de trabalho, e o comércio permaneceu como o fardo inevitável:

\begin{abstract}
Não tinha uma escolha. Meu irmão não podia achar alguma outra coisa. "Olha, eu tenho isto aqui, se você quiser trabalhar, eu te ajudo naquilo que eu conheço", que era o comercio. Eu não tinha escolha de escolher aquilo que ele ia trabalhar. Então era a lógica de me manter trabalhando no trabalho que estava sendo exercido na época por meu irmão, aí trabalhei no comercio. Trabalhei como ele, logicamente ele me deu comida, me deu a casa, me deu tudo que precisa me dar. Também era começo da vida dele, assim, não tinha grandes coisas para me dar e começou me ensinar como se faz, como é que é tanto a língua, quanto a conversa, quanto a maneira de trabalhar. Aí fui trabalhando com ele e aí trabalhei um ano com ele e depois de um tempo eu me senti que estava na hora de trabalhar sozinho.

É claro, foi uma ajuda e tanto porque no começo eu não sabia nem falar português, nem nada e trabalhei na loja dele. Ele me deu o apoio total. Seja moradia, alimentação, trabalho, etc. E fora disso, o carinho, porque, na verdade, ele é irmão do meu pai, ele é para mim que nem o meu pai. Aí então, eu tive apoio total do meu tio.
\end{abstract}

Como é possível perceber pelos relatos acima, o processo de adaptação a nova sociedade era auxiliado pela transmissão de experiência pelos já instalados. As noções mais básicas do novo idioma e das práticas comerciais eram dessa maneira assimiladas pela relação direta com estes. No entanto, estes conhecimentos representavam apenas parte do que do que precisavam saber para se virarem sozinhos no novo país. Não dispondo de qualquer forma ensino formal para instruí-los, os recém-chegados tinham que aprender o necessário através da rotina cotidiana e da convivência com os autóctones. A intensidade e a frequência dos contatos com patrícios ou parentes incidiam na capacitavam desta integração ao ambiente alheio, que independentemente permanecia um caminho a ser traçado sozinho.

No aspecto de inserção socioeconômica, Munif Omar, apesar da diferença de gerações, apresenta trajetória semelhante a Khader Othman:

\footnotetext{
Meu tio deu uma ajuda e tanto, porque no começo eu não sabia nem falar português. Trabalhei na loja dele. Ele me deu apoio total, fosse moradia, alimentação, trabalho, etc. E, fora isso, o carinho, porque, ele é irmão do meu pai. Ele é como meu pai para mim. Eu tive apoio total do meu tio.
}

No período em que a imigração contava apenas com seus primeiros pioneiros (majoritariamente homens solteiros) e ainda não havia comunidades em Santa Catarina organizadas que incorporassem os conterrâneos dentro de um espaço coletivo de preservação das tradições e quando os meios de comunicação em escala global ainda não estavam devidamente disseminados, a solidão assinalava um tipo de migração marcada pelo distanciamento com as origens. Assim, o pioneiro representava uma figura aventureira, um desbravador solitário que talvez acabasse sendo absorvido pela nova cultura, não transmitindo 
a novas gerações seu autêntico legado cultural.

Um acontecimento específico transformou esta imigração que permaneceu aproximadamente uma década como uma imigração formada majoritariamente por homens trabalhando sozinho sem suas famílias (deixadas na terra de origem), quando não eram solteiros (o que normalmente resultava no casamento com uma brasileira). A Guerra dos Seis Dias em 1967 colocou o território de onde muitos destes imigrantes vieram sob ocupação pelo exército de Israel. Esta situação fez com que a maioria dos imigrantes que tivessem mulher e filhos lá os trouxesse para o Brasil. Isto criou uma geração de palestinos nascidos e criados durante a infância na Palestina, mas que passaram o período da adolescência e fase adulta no Brasil. Assim foi para Adib Ahmad e seus irmãos:

\footnotetext{
A minha geração e de meus irmãos que vieram na época de 70 , já estava com uma situação um pouquinho melhor dos imigrantes que vieram de lá, dos palestinos e os árabes de um modo geral.
}

As gerações mais jovens, além da facilidade para o aprendizado e assimilação, encontram ao chegar "uma situação um pouquinho melhor dos imigrantes que vieram de lá, dos palestinos e os árabes de um modo geral”. Adib Ahmad conta que seu pai já estava lhe "esperando com uma certa estrutura, com uma casa alugada e uma lojinha".

Como esses chegaram ainda na infância ou na adolescência seu processo de adaptação foi diferente. Puderam encontrar um lar já estabelecido e também maior facilidade para o aprendizado do idioma, pois além da idade pueril contavam com o ensino nas escolas. Ao contrário daqueles que chegavam já no início da idade adulta que deveriam se acostumar a algo alheio, aqueles que chegavam mais jovens eram também formados nos costumes locais, não sendo para estes uma mera questão de adaptação, mas sim de conformação de duas tradições.

\subsection{Inserção no meio sociocultural brasileiro}

O desafio da inserção num ambiente culturalmente distinto, do aprendizado do idioma local e da familiarização com essa cultura varia obviamente conforme a faixa etária e, no que se refere principalmente ao idioma, com os conhecimentos anteriores de línguas mais próximas ao português que o árabe (como o francês e o inglês). As primeiras gerações de imigrantes que não tiveram conhecimento prévio nem da língua e nem dos costumes. Para alguns desses a "língua era uma dificuldade enorme", primeiramente porque "não tem escolas 
que ensinam do árabe para o português" e "você tem que apreender a machado". De modo geral, não foi esse o maior desafio para adaptação e muitos relataram facilidade no aprendizado do português pelo conhecimento anterior de francês e inglês, como para Mohammad Mahasan:

A adaptação foi boa, porque eu falo inglês, árabe, um pouco de português, um pouco de espanhol, francês e hebraico. Então, foi fácil. Em uma semana eu falava português. Não foi difícil pra mim.

Como para tanto mais, aqueles que tinham um parente próximo os auxiliando também relataram facilidade no aprendizado da língua portuguesa, como para Munif Omar:

Não digo que foi difícil a adaptação, porque, como eu tinha gente perto de mim que
sabe falar a minha língua, o árabe, e que sabe falar português, não tive muita
dificuldade. Foi pouco a pouco. Comprei uma caderneta pequena, comecei marcar
palavras e perguntar o significado e fui aprendendo. Consegui em seis ou sete meses
me comunicar com qualquer pessoa, em qualquer lugar.

O desafio da adaptação, do aprendizado da língua e da cultura, normalmente vária conforme a faixa etária. $\mathrm{O}$ mesmo aconteceu com as primeiras gerações de imigrantes, que não tiveram conhecimento prévio nem da língua e nem dos costumes. Para estes a "língua era uma dificuldade enorme", primeiramente porque "não tem escolas que ensinam do árabe para o português" e "você tem que apreender a machado". Da mesma forma foi o choque de culturas, porque "tu saia de uma cultura e entrava em uma outra cultura, tem muita coisa que é diferente, não mais certa não mais errada, são diferentes" e para um "homem de pouca experiência, se adaptar, não é fácil” As gerações mais jovens, além da facilidade para o aprendizado e assimilação, encontram ao chegar "uma situação um pouquinho melhor dos imigrantes que vieram de lá, dos palestinos e os árabes de um modo geral”, pois, como explica Adib Ahmad: "o pai já estava nos esperando com uma certa estrutura, com uma casa alugada, o pai já tinha uma lojinha".

Para esses mesmos que chegaram jovens, a dificuldade linguística é tema ainda menos relevante, de modo análogo aos signos culturais também foram mais facilmente apreendidos (e dominados), pois fizeram parte da própria formação, como expõe Adib: 
Já em relação à adaptação em relação aos costumes mostra-se uma dificuldade comum a maioria dos imigrantes que já chegaram em uma idade adulta, porque, segundo um relato representativo: "tu saía de uma cultura e entrava em uma outra cultura, tem muita coisa que é diferente, não mais certa não mais errada, são diferentes" e para um "homem de pouca experiência, se adaptar, não é fácil". Ou seja, o contraste entre as culturas leva não raro a situação embaraçosas, como a relatada pelo Munif Omar:

A cultura brasileira é uma cultura muito liberal e para nós, árabes,q ue vem lá do Oriente Médio, da Palestina ou de qualquer país árabe, a cultura é chocante. Se choca porque há muita liberdade, tudo permitido. Coisas que para nós que não existe, na verdade. A primeira vez, no segundo dia que eu tinha chegado no Brasil, eu fui com meu primo visitar um amigo dele e depois de uns quinze minutos chegou, entrou a namorada deste nosso amigo, para visitá-lo, porque ele estava doente. E ela tava cumprimentando todo mundo e dava beijo no rosto. Quando chegou perto de mim já tava tudo roxo, vermelho de vergonha. E todo mundo rindo de mim. Então, são culturas totalmente diferentes.

Mohammad Mahasan expressa ainda mais distanciamento em relação a esse aspecto liberal da cultura brasileira:

Eu não me adaptei até hoje a cultura, na realidade. Porque no nosso país a mulher anda (coberta). No começo, quando eu vim para aqui, eu me perdi um pouco, mas depois eu voltei para minha raiz. Eu acho que a cultura brasileira tem muita liberdade demais. Porque liberdade traz muita coisa, até o crime. Liberdade, álcool, droga, música de boate, isso tudo leva para um lugar muito escuro. Não se sabe onde nós vamos chegar.

No entanto, o mesmo admite também ter sido deixar por essa cultura de liberdade: "No começo quando eu venho aqui eu me perdi um pouco, mas depois eu voltei para minha raiz ấ’. Já o Munif Omar, após revelar seu estranhamento, coloca como algo possível de se conviver e vê também, paralelamente algo positivo:

\footnotetext{
Mas não é coisas que a gente não pode conviver. Eu acho que é assim: se tu aceita o que quiser, tu não aceita o que não quiser, você não é obrigado a fazer. O bom do Brasil é que o povo aceita todas as culturas, todas as religiões, todas as línguas, por isso que o Brasil tá sendo um gigante país por causa disso. Ele não tem diferenças, pelo menos que a gente vê, dentre isso para aquilo. Então, assim, a cultura totalmente diferente com a nossa, mas conseguimos se adapta.
}

Khader Othman também fala de seu espanto inicial em relação a cultura brasileira, sem entrar em detalhes ou reproches:

Para tu sair de uns costumes, de uma cultura e se encaixar em outra cultura sem preparação, olha, vou te dizer, é muito doido, é muito difícil. Tem umas coisas que tu fica assim com boca aberta, não sabe "por quê isso? Como que é isso?" 
Talvez pela experiência mais cosmopolita, Adib Al Basha não revelou o mesmo estranhamento a certos costumes brasileiros, identificando-se inclusive com alguns dos aspectos por outros vistos como problemáticos:

\footnotetext{
É um povo simpático o povo brasileiro. Na América latina em geral, eles (são) simpáticos. Não é como outros povos de Europa ou Estados Unidos, que são um pouquinho mais fechado assim. Aqui é um pouquinho mais liberal, mais aberto. Eles chegam, ajudam, conversam e brincam. Então, eu gostei muito. Sofri, tá certo, porque cada um tem uma coisa por dentro. Ele sente umas diferenças, porque eu não tenho família, não tem primos, o idioma não falo, a comida (é) diferente, o costume (é) diferente e a religião (é) diferente. Então, fiquei um pouquinho mais alertado. Mas a gente (se) adapta.
}

\subsection{Circulação migratória}

Contemporaneamente a fase imigratória encetada pela Ocupação de Israel da Cisjordânia e da Faixa de Gaza em 1967, iniciava-se a revolução da Era Informacional (Castells, 1999), processo que alteraria profundamente a natureza do fenômeno migratório contemporâneo. Inicialmente os primeiros imigrantes tiveram de passar anos sem qualquer contato regular com seus familiares. As mudanças são claras já para os palestinos que chegaram já nesta passagem da década de 60 para a de 70 quando, conforme o relato de Ahmad de Florianópolis em relação à comunicação via telefone na época de seu pai, em que "pediam para telefonista de manhã para de tarde conseguir fazer a ligação para Palestina, para depois chamar eles à tarde”. Com a maior difusão de meios de transporte, comunicação e avanços da tecnologia, que no Brasil foi impulsionada pelo período do "milagre econômico", muitos puderam restabelecer contatos e reencontrar seus parentes e sua terra natal.

A partir desse momento a imigração palestina transformou-se num fluxo migratório relativamente contínuo entre a terra natal e o Brasil, caminhando para o fenômeno caracterizado por novas circulações migrações (Peralva, 2008: 19). Além disso, as mudanças na relação entre espaço e tempo provocada pela revolução nos meios de comunicação afetam a relação dos (i)migrantes com sua sociedade de origem. Atualmente, as possibilidades de comunicação e a interação a longas distâncias com familiares e conterrâneos em diversas localidades permitem a manutenção multissituada de relações sociais e de pertença. $\mathrm{O}$ acesso rápido as informações de todos os cantos do mundo também fortalece a presença virtual da pátria longínqua e outras experiências de multipertença (Diminescu, 2008: 569). Por outro 
lado, o usufruto dessas modernas tecnologias é limitado pelas condições socioeconômicas e políticas, especialmente na Palestina ocupada por Israel.

A democratização dos meios de transporte de alta velocidade para atravessar longas distâncias favorece o retorno e a reintegração a terra natal, mesmo que temporário. Verifica-se em diversos casos idas e vindas do Brasil a Palestina, sejam elas apenas viagens de visita ou com fins mais específicos de estudos. Essas viagens não são meras excursões de turismo baratas, elas demandam muitos recursos e apoio financeiro da família através de redes de apoio que ajudam a manter os vínculos com a terra natal. Embora não haja apoio do governo ou de empresas de migração o apoio familiar estabelece uma base relativamente sólida e segura para recepção de parentes em ambos os lados. Trata-se de um tipo de família extensiva transnacional e em que os laços de apoio se verificam também no retorno aos países de origem, aonde as famílias de lá acomodam visitantes, jovens que vão morar um tempo para estudar ou simplesmente para arranjar esposas. A intenção é claramente fortalecer a tradição e a identidade do grupo assegurando uma continuidade dos costumes e da cultura de origem nas novas gerações. Viajar ou morar temporariamente no país de onde vieram seus ancestrais é para a segunda e mesmo para a terceira geração de imigrantes uma forma de conservar os laços familiares e as tradições, mesmo vivendo numa sociedade distinta.

As redes de apoio, que ainda são alicerçadas na informalidade e nos vínculos pessoais, como era o caso dos sírio-libaneses de outrora, mas que para esses se limitava mais ao nível local, agora transpõem facilmente as fronteiras territoriais e distâncias longas, fruto também da globalização que vêem crescendo nos últimos anos. Entretanto, a dimensão internacional das afiliações e a própria dimensão das famílias e das relações de parentesco (contando com dezenas e até centenas de familiares) dificultam um apoio econômico formal e constante à comunidade como um todo, sendo que a ajuda financeira é mais ocasional. Quando "um pessoa ficou doente, uma pessoa está mais necessitada na família, precisa de alguma operação, de alguma coisa, a família aqui ajuda com pouquinha coisa para cada um para essa pessoa". É cada um cuidando do seu, da sua família e quando existe uma situação extraordinária, aí então se reúne as contribuições individuais de cada integrante da comunidade para resolvê-la, como este exemplo contado pelo Adib Ahmad:

(...) outro dia teve um menino que estava com um problema na perna e precisava de uma moto especial que custava 500 dólares e aí um deu cinqüenta dólares, outro deu 30 dólares e acaba chegando esse dinheiro quando alguém passou pelo caminho aqui quando foi para lá, acabamos dando para ele e acabaram comprando esta moto. 
Redes de parentes são importantes para o próprio processo migratório (já que é necessário recursos para tal) como estratégia para manutenção dos recursos e da posição social, o que há muito tem sido feito. A manipulação dessas redes através de diferentes países permite que famílias maximizem sua utilização de trabalho e recursos em diferentes ambientes e dentro de situações de incerteza e subordinação econômica. As redes familiares podem prover a sobrevivência individual e até mesmo, às vezes, ascensão econômica num mundo de incertezas trazidas pela globalização do capitalismo tanto internamente quanto externamente (Schiller, Basch \& Blan, 1995: 54).

Atualmente, as possibilidades de manter o contato com seus familiares de fora é cada vez mais facilitado pela tecnologia que permite cada vez mais a comunicação e a interação a longas distancias, além do acesso rápido as informações de todos os cantos do mundo. Como informou Khader Othman, hoje "o mundo ficou mais pequeno, (como) uma pequena cidade, e tu podes saber de tudo e com facilidade, tanto no telefone quanto no computador a coisa é bem mais melhor do que antes".

As possibilidades de transumâncias oferecidas pelos meios de transporte mais modernos de alta velocidade permitem o fácil deslocamento para outros centros e região que facilitam o retorno e a reintegração a terra natal, mesmo que temporário. Assim se verificou inúmeros casos de idas e vindas para Palestina para Jordânia, seja para morar um tempo lá e estudar, seja para casar com pessoas de lá ou ter filhos lá (Espínola, 2005).

Como notou Jardim (2009: 198-200), na manutenção desses vínculos as mulheres desempenhas um papel fundamental. Apesar da imigração ser uma fala autorizada pelos homens, há uma rede de relações familiares tecidas pelas mulheres através de troca de informações, com um intercâmbio de fotos e encontros e re-encontros. Ou seja, há um ativo papel da mulher na configuração de matrimônios e relações familiares (conjugais sobretudo), em que estas acabam planejando viagens e deslocamento familiares. A origem árabe também é importante, pois na falta de uma mãe árabe por um filho de imigrante, a irmã de seu pai (sua tia) é que estabelece esses contatos familiares. Nota-se uma "presença ausente" desses parentes de muita significância para o grupo, já que fazem parte de uma rede familiar que disponibiliza e/ou viabiliza viagens ao exterior para morar temporariamente, participar de uma festa de casamento, etc; além de ser uma base para manutenção do vínculo e da solidariedade familiar, que serve de apoio e guia em diversos momentos e trajetórias (especialmente as específicas ao grupo imigrante). Neste "ir e vir", há um claro reflexo de uma cumplicidade (ou complementaridade) geracional entre os membros da família. 
Por outro lado, as facilidades da moderna tecnologia são limitadas pelas condições socioeconômicas e políticas, especialmente na Palestina ocupada por Israel. No caso já mencionado do Mahmoud Hussein que teve sua cidade natal obliterada pelas forças armadas israelenses, seu pai que era filho único não deixou nenhum parente lá e os contatos que tinha ali se enfraqueceram. Percebe-se que o ir e vir, visto como uma possibilidade característica da imigração contemporânea, está ligado, sobretudo, a esse vínculo familiar, a existência de parentes na terra natal.

A atuação mais direta das redes sociais para maioria dos palestinos em Santa Catarina não costumar ir muito além do círculo familiar, estendendo-se por vezes à comunidade imediata de base familiar extensiva onde se vive. Segundo Munif Omar: "O apoio depende de cada um que ajuda a família dele. Aqui também, quando se vê que alguém está necessitado, eles dão algum jeito para dar uma ajudada". Como muitas comunidades de palestinos formam-se a partir dos laços de parentesco extensivos que vinculam a família nuclear (usra em árabe), distribuída por diversos locais, à família no sentido mais coletivo $(a h l)$. "Somos todos uma família aqui, em Laguna, Imbituba, Florianópolis”, informa Abdel Muhammad. Entretanto, nem todos os imigrantes encontraram uma rede de apoio familiar no local onde se inserem.

Ao contrário da maioria dos imigrantes palestinos que se estabeleceram em uma comunidade de conterrâneos, Mohammad Mahasan é o único palestino da Faixa de Gaza e único palestino de primeira geração em Lages, referindo-se aos outros três irmãos, filhos de um imigrante palestinos, como "brasileiros, não palestinos". Seu espaço dentro da comunidade árabe muçulmana de Lages, majoritariamente libanesa, é no mínimo problemático:

\footnotetext{
Eu conheci os patrícios aqui. Eles vêm de uma cidade só. Chama Kefraya, no Líbano. E eles são unidos. Eles não gostam de mim. De ninguém de fora. Então, eu tô aqui há mais de quarenta anos e eles não me reconhecem como um membro até na mesquita da cidade. Eles não reconhecem ninguém. Apesar disso, eu era e sou ainda o imam que reza na frente deles quando eles tão aqui. Depois eles brigaram entre si e não ficou nenhum para vim aqui reza. É uma pena.
}

Abid Al Basha, que não está vinculado localmente há nenhuma rede familiar já que veio por conta de um amigo e trouxe apenas a esposa, tem uma visão um tanto pessimista das redes de apoio comunitário: 
você comer. Você tem que ajudar você mesmo. Você tem que fazer a parte tua. Como eu to fazendo a minha parte. Agora, claro, Deus ajuda todo mundo que faz bem. Agora os árabes aqui, infelizmente, eles se falam e conversam, mas se ajudar? Se ajudam entre irmãos às vezes, mas não é aquilo que você pensa. 


\section{Identidades de uma diáspora: ser palestino e brasileiro em Santa}

\section{Catarina}

A formação de uma identidade nacional palestina é um processo que em vários aspectos não difere da construção de tantas outras identidades nacionais no século XIX e XX. A construção dessa identidade foi e continua sendo sujeita a contingências, conflitos, formalizações, invenções e reinvenções de tradições, etc. Algumas características marcam de modo peculiar a trajetória identitária dos palestinos, como o desapossamento, a negação e a ocupação. O desapossamento é tanto territorial quanto simbólico, pois significou não somente a perda física de um torrão natal, mas a constante tentativa de cisão por parte do movimento sionista dos liames históricos e memoriais desse, também chamado de um "memoricídio". A negação se refere a também constante tentativa de dissolver a identidade particular dos palestinos em uma maior, a árabe, tanto externamente, pelo sionismo, quanto "internamente", pelo próprio nacionalismo árabe que serve de base para solidariedade entre as várias nações árabes para com a causa palestina. Já a ocupação refere-se normalmente a uma realidade política, ou seja, a ocupação dos territórios palestinos na guerra de junho de 1967, embora o termo também seja utilizado para referir-se a ocupação das terras durante a chamada Nakba ("catástrofe") de 1948, quando cerca de 750 mil palestinos fugiram ou foram expulsos dos territórios conquistados pelo nascente estado de Israel, além de outras formas de "ocupação" que caracterizaram a história dos palestinos que permaneceram dentro do território desse mesmo Estado. Acompanhando os habitantes do antigo território do Mandato Britânico da Palestina por onde fossem ou permanecessem, esses elementos conformavam de alguma forma a percepção que esses pudessem ter de sua coletividade.

Os palestinos e seus descentes em Santa Catarina não foram exceção a essas questões identitárias, desde o começo se relacionando de modo diverso e complexo com esses referenciais. Chegando os pioneiros a esse estado brasileiro durante a década de $1950 \mathrm{em}$ sua maioria como cidadãos jordanianos, sua relação com uma identidade coletiva declaradamente palestina era em geral frouxa, estando seu sentimento de filiação posicionado em algum lugar entre os vínculos com sua aldeia, como com sua região particular de origem, e o nacionalismo árabe (ou pan-arabismo). Somava-se a isso a necessidade de se integrar sócio, econômica e culturalmente ao espaço social brasileiro.

\subsection{A identidade palestina}


A Palestina como imagem ou projeto de nação é, como tantas outras nações do mundo, um fenômeno da modernidade, fruto do processo de transformações ligadas às grandes revoluções do século XVIII e XIX. Portanto, as bases do nacionalismo palestino não são mais nem menos legítimas ou originais do que qualquer outro nacionalismo no mundo, estando como todos esses outros sujeitos às mesmas mudanças e construções, bem como relações dialéticas com outros nacionalismos.

Além dos grandes processos, tanto sociopolíticos quanto ideológicos, como a formação de estados nacionais com suas divisões definidas pelas potências ocidentais, o panarabismo, as correntes dentro do Islã, o sionismo, houve também muitos fatores locais, identidades e lealdades baseadas na família, na elite local, na região e na vila de habitação ou de origem. Embora não fossem exclusivos da Palestina, aqui como em outros lugares, forneceu as bases para um nacionalismo baseado na topofilia, no amor ao país e no patriotismo (Khalidi, 2010: 21).

Como entre tantas narrativas nacionais, no caso Palestino também existe a tendência a observar a identidade palestina (a "palestinidade") como algo essencial, atemporal, provindo de tempos imemoriais, ignorando assim fatores contigentes e toda uma diversidade social e política. Portanto, a Palestina não é uma entidade metafísica imemorial, eterna e imutável, como também não o é nenhum outro estado-nação. Suas fronteiras não são uma demarcação que obedece completamente os sentimentos de pertencimento, as identidades e as características culturais de uma unidade definida como país ou região, tanto quanto todos os países estão cindidos por divisões internas que extrapolam o limite de uma determinada territorialidade. Nem é a Palestina uma necessidade histórica, podendo ter se tornado, independentemente de suas particularidades regionais, parte de um país maior ou se subdividido, nem tão pouco preservado a mesma configuração territorial do momento do Mandato.

Por outro lado, há uma tendência olhar para o fenômeno apenas pelo viés das influências externas, que também não podem ser superestimadas, pois há a tendência a imaginar o nacionalismo como fruto de elementos puramente exógenos e/ou uma resposta ao sionismo, sem o qual não existiria:

É até mesmo mais patente que a experiência comum do estabelecimento e da conquista sionista seja o que criou o nacionalismo palestino associado a um território que, até 1918 , nem mesmo tinha qualquer identidade regional significativa dentro da Síria meridional, à qual pertencia. (Hobsbawn, 1995: 166) 
A existência de uma cultura local particular não se traduz inexoravelmente numa comunidade política, nem, qualquer que seja sua especificidade, ela é algo tão homogêneo e coeso que não passa se subdividir ou ser incorporada a uma entidade maior, o que por sua vez não significa seu anu lamento no todo maior. A relação dialética com o sionismo em particular forneceu ao nacionalismo palestino sua contraimagem, quanto esse àquele. $\mathrm{O}$ nacionalismo palestino não é um fantasma da imaginação construído por invenções a respeito de uma região geográfica, de sua população e de seu povo, apenas como uma inversão, uma contrapartida para o sionismo. Independentemente do que pensavam os habitantes daquela região anteriormente a chegada do sionismo e quais fossem suas filiações e sentimento de pertencimento coletivo, sua existência e relação com sua terra é inegável, a não ser na ótica das mentalidades colonialistas. Do mesmo modo, essa existência é fruto de sujeito a mudanças históricas. Não é menos verdadeiro para todas outras nações, como para tudo que constitui a sociedade humana.

Em suma, como notou Farah (2004: 65), "libaneses, sírios, iraquianos e jordanianos buscavam desenvolver seus respectivos nacionalismos durante o mesmo período sem o benefício duvidoso do desafio sionista". As falhas e os infortúnios que se manifestaram sobre a Palestina serviram para gerar uma experiência comum e completar o processo de formação de uma identidade nacional anterior a 1948. Isto permitiu uma universalização de uma identidade uniforme (Khalidi. 2010: 34). O sentimento de pertença a uma comunidade mais ampla foi inicialmente mais forte entre as camadas urbanas da população, desenvolvendo-se à medida que a modernidade se inseria na realidade da Palestina com a difusão do ensino, a abertura de estradas, a construção de ferrovias, etc.

O colonialismo e o sionismo vieram sim a moldar o que veio a ser a Palestina e o nacionalismo palestino, mas não de modo exclusivo ou inevitável, pois os dois fenômenos também foram influenciados por processos maiores e condicionados pelas transformações da modernidade. A ausência de colonialismo ou de sionismo não impediu a formação de tantas outras nações. Sem dúvida exerceram um papel dialético essencial na formação do nacionalismo palestino como ele é. A existência anterior de uma Palestina como região (ou agrupamento de regiões) e de um povo particular a ela não é necessariamente sinônimo de uma consciência coletiva desse fato através do nacionalismo. 
O legado herdado dos primeiros expatriados mantém vivo os vínculos com um solo palestino onde as evidências materiais e físicas foram obliteradas. O Estado de Israel formulou a legitimidade de sua existência extinguindo da história os vestígios que não lhe convinha. A resistência à investida contra o passado, a expropriação intelectual do direito ao retorno, veio da lembrança e da identificação nutrida pelo país, esta memória patriótica. A resposta dada pela ex-primeira-ministra Golda Meir a pergunta sobre a existência de um povo palestino é ainda relembrada e exemplifica este dilema: "Não conheço, ela disse, não conheço um povo chamado palestino. Mas e esses atentados? Ah, eles são árabes, não são palestinos" (Espinola, 2005: 184). A afirmação e consciência nacional palestina talvez tenha sido uma das armas mais poderosas e indispensáveis para os palestinos neste conflito.

Entre os imigrantes palestinos de Santa Catarina, a situação da Palestina é ao mesmo tempo um emaranhado de experiências pessoais traumáticas e discursos sobre a situação presente. Mohammad Mahasan, falando de sua experiência pessoal como duplamente refugiado, isto é, de Jaffa e da Faixa de Gaza, insere-a dentre de uma realidade genérica que atinge coletivamente a maior parte dos palestinos: Mandaram todo mundo embora. Tão em todo lugar do mundo. A minha mãe e o
meu pai morreram lá na minha terra, mas eu não pude ir lá ver eles, porque o judeu
não aceita.

Abdul Oda, antes de relatar sua experiência pessoal que o levou a emigrar, descreve a situação por ele mesmo vivida como característica de uma experiência de opressão coletiva compartilhada pelo povo ao qual pertence:

(...) nosso país nunca foi um país independente. Não tinha liberdade, sempre foi dominado. No meu tempo, era Inglaterra que dominava minha terra. Então, nós nunca tínhamos liberdade para estudar, para nada.

Não apenas em sua terra natal, palestinos são lembrados de sua situação. Em uma viajem para o Egito em 1987, Abid Al Basha revela a frágil condição de ser palestino:

Eu faço caricaturas e desenhos da Palestina e do sofrimento do povo palestino. A OLP A OLP me mandou falar com um escritor no Cairo, Egito. Falei: "Vou". Levei vinte desenhos meus e fui para o aeroporto. Saí e fui para o Cairo. Desci no Cairo, mas eles chegaram para mim com o passaporte jordaniano (escrito) nascido em Nablus, Palestina. Meu nome tava bem parecido com de um primo que tem nome parecido comigo. Ele tinha uma ordem de prisão lá no Egito. Aí, eles falaram para mim que eu mesmo tava com ordem de prisão. Eu falei, "mas eu estudei na Jordânia, eu fiz faculdade lá". E a idade diferença com aquele que eles queriam naquela hora. Ele tinha trinta e poucos anos. Eu tinha na época, vinte anos ou mais ou menos dezenove anos. Não adiantou nada. Eu tive que ficar lá vinte e quatro horas no aeroporto, respondendo para eles. E, no final, eles me colocaram no avião e me 
mandaram de volta para Jordânia. Não acreditei. Não consegui entrar no Egito, porque ou entro e (vou) preso ou não entro. Eu preferi não entrar, porque tu não sabe o que é prisão lá.

Khalidi (2010: 2) explana como as fronteiras são problemáticas para os palestinos por estarem, em muitos casos, sujeitos a suspeita, podendo por isso estarem expostos simplesmente por causa de sua identidade ao assédio, exclusão ou pior. O medo (receio) que essas fronteiras despertam nos palestinos ao mesmo tempo reforçar, mesmo que negativamente, sua própria identidade.

Observa-se já na relembrança dos primeiros anos de idade entre os imigrantes e descendentes a tentativa de acomodação na memória com esse conjunto de referenciais que se sobrepõem, mudam e/contrapõem-se conforme o lugar e o momento. Khader Othman, comerciante palestino nascido em 1939 e que imigrou para o Brasil em 1966, presenciou em tenra infância o desenrolar do maior trauma na memória coletiva dos palestinos, a Nakba (catástrofe em árabe), quando aproximadamente 800 mil palestinos foram desapossados de seu torrão natal. Quando perguntado sobre as lembranças de sua infância, ele responde não têla desfrutado muito, pois cedo teve que trabalhar, pois seu pai morreu cedo e ele era o único filho mais velho presente. Nenhum detalhe dá sobre sua própria infância, exceto desse acontecimento que mantém guardado forte em sua memória apesar de já terem se passado mais de 60 anos:

[...] a coisa que até agora mais esta viva na minha memória, depois sessenta anos, está bem viva, são aqueles momentos em que eu vi, quando eu estava com praticamente nove anos, os palestinos se refugiando, sendo expulsos da sua pátria, de suas terras e de suas casas e passando pelo povoado onde nós morávamos. Alguns ficavam lá conosco naquele povoado ali e nós e os nossos pais oferecíamos comida, água e o pessoal depois ou ficava lá ou continuava para o destino final...

Sempre me lembro que com aquelas pessoas vinha uma coisa muito importante na mão: a chave da casa que elas fecharam por uns 10 ou 15 dias para depois voltar, pois não imaginavam o tamanho da tragédia que estava sendo cometida contra o povo palestino naquela época. Eles achavam que "não é possível que vá acontecer isso, a gente vai sair um pouco, depois os governos árabes, o povo árabe...", ele vai forçar a sua volta para sua casa e a normalidade ia retornar.

Ao tratar de tal assunto, Othman logo revela lembranças pessoais, isto é, como ajudou os refugiados que passavam por sua vila, sendo sua participação tanto individual quanto coletiva subtendida pelo uso do pronome "a gente" e depois "os pais e nós". Pollak (1992: 212) vê no uso de diferentes pronomes indicadores do nicho social do qual o entrevistado pertence como também o grau de distanciamento em relação à experiência. O uso de "a gente" e da uma terceira pessoal no plural normalmente relata uma experiência além do controle humano ou pode-se derivar daí também uma regra, algo convencional. Já o pronome 
"nós" normalmente relata uma experiência coletiva da qual o indivíduo sente-se parte. Aqui a utilização desses três diferentes pronomes para mesma ação parece reforçar tanto uma resposta coletiva necessária diante de tal situação, "um dever de todos" por assim dizer, quanto à voluntariedade daquele que se sente parte dessa coletividade em "fazer a sua parte".

Como é possível perceber, as lembranças não apenas revelam um passado exatamente como o indivíduo a percebia naquela época, pois, na própria narrativa, conexões já são feitas com outras temporalidades. O relato de Othman revela essa conexão ao falar da chave que os refugiados carregavam em sua mão sem se darem conta naquele momento do "tamanho da tragédia que estava sendo cometida contra o povo palestino naquela época". A frase revela uma dimensão espacial e temporal maior que a experiência tal como presenciada no momento, algo que apenas o conhecimento posterior podia acrescentar. Desse modo, à lembrança daquele evento associa-se uma memória coletiva que lhe dá um sentido e que assim tornar-se parte indissociável dessa lembrança. A importante da coletividade acaba por ganhar precedência na narrativa, de modo quem numa ordem que vai do mais coletivo para o mais particular, Othman relata que os palestinos foram expulsos de "sua pátria, de suas terras, de suas casas".

Khader Othman é dentro da comunidade um dos principais porta-vozes da causa palestina e ativamente envolvido em sua promoção. Esse nicho social que ocupa pode ser uma das razões da proeminência que a coletividade palestina ganha em sua narrativa. Entretanto, comparando seu relato com de outro imigrante de primeira geração e que chegou ao Brasil também como adulto, mas que não é tão ativamente envolvido com a causa palestina, é possível notar muitos paralelos, apesar de suas datas de nascimento estarem separadas por décadas.

Nascido no ano de 1968, ou seja, um ano após a ocupação da Cisjordânia e da Faixa de Gaza, Munif Omar cresceu dentro de um contexto muito distinto daquele de Othman. O modo como narra suas lembranças de infância revela essa diferença entre a lembrança de um momento traumático para memória coletiva, mas do qual como indivíduo não se é inteiramente parte, e a experiência cotidiana da ocupação, a inevitabilidade de enfrentar mesmo individualmente as dificuldades criadas por essa situação. Em ambos os casos, a vivência da infância é vista como efêmera (Othman) ou não autêntica (Omar). Porém, enquanto para Othman isso se deve a uma situação particular, de sua família, para Omar a ausência de uma verdadeira infância advém de uma força maior, isto é, a ocupação: 
A infância na Palestina, a gente, na verdade, nunca tivemos infância, porque, desde que a gente nasce, vai crescendo, vai convivendo com o problema da ocupação na Palestina. Então, a gente não tinha como as outras crianças do mundo lugares para brincar. Não tinha lugares específicos para passar o tempo depois da aula, ou em casa ou nas ruas.

Os eventos de 1967 também exacerbaram para a comunidade as questões já trazidas pelo trauma coletivo das investidas por parte de sionistas contra a existência e autodeterminação nacional do povo palestino, especialmente em 1948, quando cerca de 750 mil palestinos tornaram-se refugiados de seu país após a criação do Estado de Israel. Com isso, a identidade e a luta palestina foram se fazendo mais presente no mundo e entre as comunidades palestinas dispersas. Como explica Gopal Balakrishnan, "só na luta a nação deixa de ser um quadro de referência informal e apenas presumido como certo, transformando-se numa comunidade que se apodera da imaginação" (Balakrishnan, 2000: 221). Neste caso, a ligação dos palestinos com sua região é um elemento central desta nação que se "apodera da imaginação" e torna-se objeto principal da luta e da resistência, de significado fundamental para identidade palestina. A relação entre identidade e espaço, tão importante para os palestinos, foi descrita por Paulo Farah da seguinte forma:

\footnotetext{
O espaço é uma força estruturante fundamental para o sentido de identidade e para a relação com o mundo material. Consequentemente, uma ruptura do liame com o espaço leva a várias formas de fragmentação social e psicológica. Em verdade, essa é uma das razões pelas quais a tentativa de reaver a terra é de importância tão vital para os povos expulsos de seu torrão natal: faz parte de um esforço para adquirir uma visão unificada do eu, do mundo e da experiência coletiva. (FARAH, 2004: 53)
}

A ausência deste lugar tão significativo é conciliada na memória e na identidade dos palestinos, que criam esta "visão unificada do eu, do mundo e da experiência coletiva". O rompimento concreto com as raízes é substituído por uma re-elaboração imaginária do espaço em que o conceitual e o abstrato procuram suprir a privação da experiência direta. Seja na memória ou na literatura, o "desapossamento traçou uma nova geografia para os palestinos, a da ausência, da memória (ameaçada constantemente pelo esquecimento) e do imaginário individual e coletivo" (Farah, 2004: 55). Todavia, esta nação traçada no pensamento não substitui e nem sublima a necessidade de um lugar primordial, de um ponto de referencia. $\mathrm{O}$ exílio gera impressões que diferem do nacionalismo como normalmente concebido, ou seja, o sentimento de estar conservando e defendendo uma nação unida e que pertence inaliavelmente a seu território e a sua população. Ao invés de vivenciar esta experiência, o exilado almeja esta situação: 
O exílio, ao contrário do nacionalismo, é fundamentalmente um estado de ser descontínuo. Os exilados estão separados das raízes, da terra natal, do passado. Em geral, não têm exércitos ou Estados, embora estejam com freqüência em busca dele. Portanto, os exilados sentem uma necessidade urgente de reconstituir suas vidas rompidas e preferem ver a si mesmo como parte de uma ideologia triunfante ou de um povo restaurado. $\mathrm{O}$ ponto crucial é que a situação de exílio sem essa ideologia triunfante - criada para reagrupar uma história rompida em um novo todo - é praticamente insuportável e impossível no mundo de hoje. (Said, 2003: 50)

"A ideologia triunfante" dos palestinos é sua própria causa, seu próprio desejo de retorno, que tem sido disseminada por palestinos tanto em sua terra quanto na diáspora em termos universalistas. Dessa maneira, ao invés de propagada como um direito exclusivo do povo palestino que só interessaria aos mesmos, a causa palestina atrai a atenção e o comprometimento de muitos não-palestinos, rompendo com a barreira que opõe "nós" e "eles" em nome de um objetivo particular a um povo, mas de causa universal. "A causa Palestina eu acho que é a causa do mundo inteiro", "a questão palestina é a questão mais justa do mundo", "A causa palestina é uma causa que hoje une pessoas de todas as partes do mundo pela sua legalidade, pela sua dignidade, porque é uma luta nacionalista". Frequentemente, são nestes termos de caráter universalista é descrito por estes imigrantes a causa dos palestinos. Mesmo sendo um luta nacionalista, o que indicaria uma particularidade, ela tem seu apoio em valores humanistas. $\mathrm{O}$ apelo universal a solidariedade ao povo palestino indica uma identificação que rompe as barreiras de pertencimento e nascimento em um meio e um grupo específico.

O grupo Sanaúd (Jardim, 2000), comitês de solidariedade (Voigt, 2005) e outras associações criadas em diversas cidades do Brasil desempenham para os palestinos um papel local dentro da batalha pela opinião pública que o povo palestino trava mundo afora. Palestinos vivendo em diferentes países buscam expandir o apoio internacional à sua causa. A solidariedade do Outro é um elemento essencial na luta político-ideológica pela libertação da Palestina, pois incentiva a aversão e repúdio da comunidade internacional à ocupação israelense. Os vínculos de solidariedade estabelecidos por um contato direto com as populações locais pelos imigrantes palestinos busca contrabalancear a menor influência que possuem na mídia ocidental (America Latina inclusa), de onde provém apoio mais significativo a Israel. A cooptação política dessas populações faz parte da difícil tarefa de imprimir a contraditória figura de um Estado judeu opressor num imaginário já fortemente marcado pela vitimização dos judeus e pelos efeitos nefastos do antissemitismo.

Ao se inserirem numa cultura diferente, bem como em outra realidade sociopolítica, os palestinos tiveram de lidar com mudanças e dilemas em relação aos hábitos e a própria autodefinição. Assim, a comunidade palestina de Santa Catarina procurou várias maneiras 
negociar sua identidade com a sociedade autóctone. Uma das estratégias de cooptar para os ideais políticos e identitários palestinos a sociedade catarinense, particularmente a florianopolitana, foi a formação do Comitê Catarinense de Solidariedade ao Povo Palestino. Fundado em 2002, o Comitê tem como objetivo principal a difusão da causa palestina e ações de solidariedade com refugiados, sendo aberto a todos que são solidários à causa palestina (AN Capital, 2002). O comitê origina-se em parte da antiga comunidade Associação ÁrabePalestina-Brasileira com sede em Tubarão, que esteve ativa até 1987 (ESPINOLA, 2005: 179). Até a criação do Comitê de Solidariedade ao Povo Palestino, várias manifestações coletivas envolvendo palestinos, árabes e brasileiros foram realizadas em nome de uma Palestina livre, como as passeatas de 2000 (A Notícia, 2000), seguida de várias outras a partir da criação do Comitê. No plano institucional foi criada a Lei Municipal No. 3440/90 de 17 de agosto de 1990, que institui o Dia Municipal de Solidariedade ao Povo Palestino (29 de novembro) ${ }^{11}$ em Florianópolis, seguida vários anos depois pela Lei Estadual No. 13.850 de 17 de novembro de 2006, que institui a mesma lei em toda Santa Catarina ${ }^{12}$.

$\mathrm{Na}$ cidade de Criciúma, a estratégia de inserção e manifestação da comunidade palestina manifestou-se através participação na Quermesse de Tradição e Cultura, ou "Festa das Etnias", e a construção da mesquita. A questão étnica nesta cidade provém de uma iniciativa pública de definição de uma identidade urbana multi-étnica, da qual diferentes grupos buscaram se beneficiar em sua inserção (CARDOSO, 2008: 162). Já na segunda edição desta festa, o grupo étnico árabe se junta às outras cinco já anteriormente consolidadas (alemã, italiana, polonesa, portuguesa e negra). Ao tomarem parte da Quermese, o grupo árabe utiliza de uma série de símbolos inseridos dentro de uma imaginário de oriente exótico que identificam sua etnicidade, como imagens de odaliscas e o narguilé, além dos identificadores mais claros da etnia no Brasil: a culinária e a dança ${ }^{13}$. Para representar o grupo árabe como um todo, chegou a ser utilizada a bandeira da Liga Árabe. Entretanto, a bandeira da Palestina acabou por ser escolhida por ser a maioria dos árabes de Criciúma palestinos e pela solidariedade conjunta com a causa Palestina (Cardoso, 2008: 167).

Os árabes de Criciúma formam um grupo por 15 a 20 famílias com forte presença no comércio, possuindo algumas das lojas mais tradicionais da cidade. Porém, seu principal espaço de afirmação é a mesquita. A partir da Sociedade Beneficente Muçulmana de Criciúma foram reunidos recursos para construção da Mesquita Palestina que se próxima ao

\footnotetext{
${ }^{11}$ www.cmf.sc.gov.br/ acesso em 28/10/2010

12 http://200.192.66.20/ALESC/ acesso em 28/10/2010

${ }^{13}$ Estes são os dois temas tratados na reportagem sobre os árabes na Festa das Etnias. http://www.radiocriciuma.com.br/portal/vernoticia.php?id=985 acesso em 01/10/2012
} 
Paço Municipal, local onde se situa a Prefeitura, o Teatro, a Biblioteca e o Ginásio municipais; e que na época do centenário foi construído um monumento aos fundadores da cidade. Ali também foi realizado durante muitos anos a Festa das Etnias. A marca territorial desta etnia se faz presente não apenas pela localização em si, mas também pelo nome da rua em que se localiza: Rua Palestina, como também da praça a frente da mesquita que também foi nomeada conforme a sugestão do grupo: Praça Jerusalém (Ibidem).

Organizações são formas de manutenção a etnicidade e demarcação espaços, tanto físico quanto simbólicos. Como já foi explanado, esse espaço em Criciúma é a Mesquita Palestina. Abdul Oda fala a Sociedade Beneficente Muçulmana foi fundada em 1980, mas começo foi em 1992, mas foi inaugurada em 1999 2000. Munif conta que:

\begin{abstract}
A mesquita foi inaugurada em 1999. Mas a sociedade beneficente muçulmana foi fundada há muito tempo atrás. Começaram a juntar dinheiro e participar na festa das etnias para juntar dinheiro. $\mathrm{O}$ que vinha de lucro naquela época ia lá para construção dessa mesquita. Foi mais ou menos quinze anos antes de construir a mesquita.
\end{abstract}

Apesar de tudo que representam a Mesquita Palestina e atividades como a Festa das Etnias, Munif Omar lamenta a descontinuidade dos laços com a tradição, costume e religião (especialmente a última), entre as novas gerações:

Como agora, infelizmente, a nossa etnia tá menor, pois muitos viajaram daqui, saíram daqui, às vezes, chegam 15 ou 17 pessoas no máximo a frequentar a mesquita.

Para ele, isso se deve ao desaparecimento das primeiras gerações e descontinuidade das gerações de árabes muçulmanos na cidade:

Eu acho que tem de dez a quinze famílias palestinas aqui. O problema é que em algumas famílias, o pai que era árabe faleceu. Alguns se afastam um pouco, não vão à mesquita, não se enturma um pouco mais com a sociedade ou com a etnia árabe.

3.2 O Brasil para seus imigrantes palestinos

Apesar de por vezes visto como "liberal de mais", Brasil o surge na narrativa dos imigrantes palestinos de modo geral não só como uma terra de acolhida, mas o "melhor país do mundo", fato vinculado, na visão dos mesmos, a aceitação incondicionál de estrangeiro e a igualdade entre seus cidadãos. Para Abdul: “O Brasil é o melhor país do mundo. Eles recebem estrangeiro aqui e não tem diferença se tu (é) judeu, se tu (é) palestino, se tu (é) negro, se tu (é) branco. É tudo igual." Entusiasta da visão de Brasil como terra de tolerância e igualdade, Abid Al Basha afirma que: 
Não tem melhor que o Brasil no mundo. Eu viajei. Fui para Alemanha, Holanda, Itália, Espanha, França, mas claro, não fiquei muito tempo. Fiquei um mês ou um mês e pouco. Mas não me adaptei. Não me agradou. É claro que tem o lado bom e o lado ruim. Mas eu acho que não tem futuro como o do Brasil. Não tem país livre como o Brasil. Não tem democracia como existe no Brasil, hoje em dia. Nem ontem, nem hoje. Não existe. Brasil, eu acho, tem como crescer muito mais ainda. (...) a gente sente que o Brasil é nosso lar. A gente não está fazendo isto para ganhar simpatia, pois realmente a gente sente. Como nós somos estrangeiros, a maioria do povo que hoje constitui o Brasil, ou alemães, ou poloneses, ou americanos, de todas as raças e de todas cores vem aqui para este Brasil e todas elas não se sentem dono da terra. Então a gente não sente discriminação nenhuma.

\section{Em relação Adib Omar Mahmoud Ahmad}

Então, isso no Brasil é muito bonito, isso é muito correto. A gente não sente que ninguém quer dizer para você, a eu sou o dono da terra, você não é o dono da terra, não existe isso no Brasil.

A perspectiva de Mohammad Mahasan já inclui outros elementos, como a riqueza natural do país e "Brasil aqui é mãe do mundo. É o melhor país do mundo. Tem gente pobre porque quer. Porque não quer trabalhar, não é verdade? O Brasil é uma maravilha se comparado com país árabe. Brasil (é) o paraíso de Deus. Tem água, agricultura.” Por fim, manifesta a admiração pelas mesmas qualidades prezadas pelos outros imigrantes:

Nós árabes acreditamos no Brasil. Tem mais de cinco milhões de árabes aqui, nós agradecemos muito o Brasil e a solidariedade brasileira. Tem um ou outro, mas $99 \%$ acha que não tem diferença entre árabe, italiano, alemão. Ao contrário, eles tratam a gente muito bem e nós sentimos a Pátria brasileira é nossa Pátria. Eu vou morrer um dia e vou deixar seis filhos, netos. Vai ser uma família bem grande servindo o Brasil até para sempre.

É a mesma posição revelada por Munif Omar, ao colocar que:

O bom do Brasil é que o povo aceita todas as culturas, todas as religiões, todas as línguas. Por isso que o Brasil tá se tornando um gigante. Ele não tem diferenças, pelo menos que a gente vê. 
Mas o que explicaria tal nacionalismo exacerbado por parte do imigrantes palestinos em Santa Catarina? Certamente, o Brasil mostra-se muito mais receptivo a muitos imigrantes que passaram por sofrimentos e formas institucionalizadas de discriminação por conta da origem/nacionalidade/ etc. Como a maioria veio já adulta, não há como supor um papel tão direto da ideologia propagada pelo Estado na formação educacional desses mesmos imigrantes, embora seja evidente existir alguma influência mesmo que indireta. A ideologia da "democracia racial" professada pelas elites brasileiras é difundida nos meios de comunição hoje em dia, talvez mais do que nos órgãos oficiais que já aceitam implicitamente incorporam uma crítica a essa visão ao introduzirem medidas como a de cotas. Entretanto, não podemos reduzir apenas a uma ideologia. É preciso entender como se manifesta dialeticamente entre os imigrantes e quais suas contradições.

Tanto individualmente, como coletivamente, todos os imigrantes palestinos aqui apresentados viveram a dramática experiência de ser palestino de algum modo ou de outro. Tendo em vista sua árdua trajetória, bem como a da maior parte de seus parentes, Abid conclui que:

\begin{abstract}
Em nenhum país árabe, um palestino nunca tem direito como o outro. Por exemplo, na Síria, não tem direito como sírio. No Líbano, ele não tem direito como libanês. No Egito, ele não tem direito como egípcio. Na Jordânia, ele não tem direito como jordaniano. Na Arábia Saudita, a mesma coisa. No Iraque, a mesma coisa. Então, eu achei que o mais certo era um país longe de nós como o Brasil. E aqui achei o lugar mais certo, mais direito. Eu tenho direito a mesma coisa que você, a mesma coisa do que os outros brasileiros. Eu sou naturalizado agora, mas eu tenho direito a mesma coisa que você e os outros brasileiros. Isso aqui a gente não acha lá no Oriente Médio. Infelizmente.
\end{abstract}

Ao mesmo tempo em que vê o Brasil como "liberal demais", como um local onde há risco se você "sair de noite é assaltado e pode ser morto", diferentemente em sua visão de países que aplicam rigidamente a lei islâmica como a Arábia Saudita, Mohammad Mahasan diz não ter qualquer queixa do país e jamais ter sofrido preconceito: "E eu tenho 66 anos. Eu cheguei com 25 anos. E não tenho queixa nenhuma do Brasil. (...) Não sofri preconceito aqui. O brasileiro é maravilhoso".

\title{
3.3 Identidades sobrepostas
}

Presente no discurso de quase todos os imigrantes palestinos, está a dualidade entre ser brasileiro e ser palestinos. Desde de modo casual, como Abdul Oda, quando se refere as viagens realizadas a Palestina e ao constante interrogatório pelas autoridades israelenses, nós (somos) brasileiros com passaporte brasileiro até explicitamanete, como na fala de 
Mohammad Mahasan, quando afirma que se define apenas como "brasileiro. Só. Porque mesmo que eu queira ser palestino, a Palestina não existe."Ao mesmo tempo, ao falar dos palestinos de Lages, diz que: "De palestino sou eu e mais três. Eu sou da Faixa de Gaza e os três nasceram no Brasil. Eles (são) brasileiros, não palestinos. Quando nasceram, o pai deles levou eles para lá. Eles falam um pouco de árabe". Ou seja, ao mesmo tempo são e não palestinos, como ele mesmo é e não é palestino. A dubiedade não é tão presente em outros relatos, que procuram aliar as duas identidades de modo mais coerente, como na fala de Munif Omar:

\footnotetext{
Eu me identifico, claro, como um palestino. É minha raiz. Lá que eu nasci, fui criado e estudei. É lá que eu tenho meus parentes. Isso não quer dizer que se eu me identifico como palestino, eu não estou considerando o Brasil, pelo contrário. Porque chega um certo tempo e estás dividido.

(...) eu estou aqui há 18 também anos. Eu vivi na Palestina também 18 anos. Imagine como é que eu estou. Pode ser que meu sangue (seja) árabe, mas meu coração (é) brasileiro.
}

Mais claro ainda é a posição de Abid Al Basha ao dizer "Eu sou naturalizado agora, mas eu tenho o mesmo direito que você e os outros brasileiros (...) eu tenho orgulho de ser brasileiro e palestino". Sua trajetória em particular revela o modo como valoriza tanto a nacionalidade brasileira, quando fala de sua esposa:

\begin{abstract}
como minha esposa, por exemplo. Ela nasceu no Kuwait, mas ela não tem nacionalidade kuaitiana. Ela não podia. Não tem como. Ela pode pegar somente a nacionalidade do pai dela. O pai dela (é) palestino. Então, como é que ela vai pegar? Ela tem que pegar um (documento) palestino provisório até para ela manter a vida dela, para ela viajar. Mas (não) nacionalidade certinho, como ela tem hoje. Ela tem naturalização brasileira. Ela tem dupla nacionalidade hoje. Ela anda com um passaporte da Jordânia provisório que sempre renova e como brasileira naturalizada
\end{abstract}

Percebe-se nesse caso a contradição notada por Osman (2008: 7) no discurso identitário de imigrantes libaneses:

Há também que verificar a contradição dentro de uma mesma narração, no sentido em que ao mesmo tempo em que "se sente igual, sem diferença", se afirma "ser brasileiro"; da mesma forma que se "sente as duas coisas" e se convive com a idéia de ser estrangeiro", do mesmo jeito que se sente "brasileiro e libanês", não há como negar que "brasileiro é brasileiro".

Entretanto, há uma importância central para questão do retorno como central entre os entrevistados na pesquisa de Osman, sendo para esses a migração um fenômeno marcadamente transitório, fato que não se verifica no caso dos palestinos aqui estudados, para os quais a questão do retorno a uma pátria cujo status é indeterminado. A resposta de Abid é reveladora desse dilema: 
Voltar aonde? Com certeza, eu voltaria, mas eu não deixava de viver no Brasil. Eu tenho apartamento e negócio aqui. (...) Claro, eu viajaria para lá, ficaria lá até voltar aqui. Ou fazia escala entre meu país natal e aqui. Mas eu não largava Brasil nunca. E eu sofri para sair de lá. E se ela voltar para mim, claro que eu vou sofrer para voltar para lá também. Mas eu não vou deixar o Brasil. Não é meu pensamento deixar o Brasil nunca.

Abdul Mohammad Oda manifesta o desejo de poder viver entre os dois lugares. Como Visitar já algo que faz com certa regularidade, o que parece desejar é mais a possibilidade de melhor uma condição existente, torná-la ideal, estendê-la no tempo, mais que propriamente realizar alguma mudança:

Eu amo o Brasil. Amo quando vou visitar minhas filhas. Dá trinta dias, não vejo a hora de voltar para o Brasil, mas com essa idade que eu tenho eu gostaria de voltar. Voltar lá e ficar aqui. Esse é o meu pensamento.

Mohammed Mahasan, cujo retorno está em tese impossibilita pelo bloqueio à Faixa de Gaza, diz não manifestar o desejo de retorno verdadeiro, pois constitui sua vida no Brasil durante 40 anos de sua vida, a qual limitou-se muito mais a esse país, diferentemente de outros imigrantes que puderam "ir e vir" com mais facilidade:

Se eu voltar lá, eu volto como visita, como turista. Mas para ficar lá, não. Mesmo se eu vou lá e quiser ficar lá, se eles me amarraram lá, eu não fico. Porque faz quarenta anos que eu tô no Brasil. Tomei muitas coisas dos brasileiros. Se eu chegar lá, vai mudar toda minha vida. Depois eu tenho seis filhos aqui. Tenho neto. Não tem. A Pátria é aqui e acabou.

A visão de Munif Omar é muito próxima a de Mohammed Mahasan e de Abdul Oda, embora ele a expresse em mais detalhes seu sentimento de ligação com a terra natal, a qual não visita desde que chegou ao Brasil no início da década de 1990:

A saudade é enorme, mas para voltar para morar lá, eu não penso nisso não. Pretendo continuar vivendo aqui no Brasil. Agora já estou começando a fazer minha naturalização para virar um cidadão brasileiro com todos meus direitos, como de votar, etc.

Visitar de vez em quando, ter lá minha terra natal. Tem a minha infância, a minha família, os meus amigos de infância. Tudo isso a gente nunca esquece.

Então, eu gostaria de visitar, mas de voltar a morar lá eu acho que não.

Então, ele quer sempre estar ligado. Nós também temos esta ligação. A cada dois anos, a cada três anos, quando a situação do conflito permite, a gente vai lá passear, vê a família, eu tenho irmã, eu tenho tio, eu tenho tias, eu tenho sobrinhos, porque quase toda minha família, toda estrutura familiar, está toda lá. Então, esta inda e vinda, a gente precisa dela. Não tem como você dizer: "Ah, não! Nunca mais vou voltar lá’. Então, tem essa ligação. 
A naturalização foi a opção de muitos palestinos, principalmente depois quando no Brasil tornou-se possível adotar a dupla nacionalidade. Os naturalizados abraçaram a brasilidade, sem entrar em contradição com a "palestinidade". O lado pragmático da naturalização é claro nas viagens internacionais feitas sob as proteções legais garantidas pelo passaporte brasileiro, em que mesmo com um nome que revela a identidade árabe, "até dentro de Israel a gente é considerado brasileiro". Frases como "eu sou brasileiro" e "eu sou bastante brasileiro" são ditas por pessoas que em outro momento haviam se declarado palestinos (Espinola, 2005: 220). Esta situação em nada difere da que Lesser havia notado com outros imigrantes em outras épocas:

As etnicidades trazidas e construídas por esses imigrantes eram situacionais, e não "identidades primordiais imutáveis". Em diversos momentos, os imigrantes e seus descendentes puderam abraçar sua "niponicidade" ou sua "libanicidade", tanto quanto sua "brasilidade". (Lesser, 2001: 27)

Esta situação pode ser ainda mais paradigmática como ambígua no Brasil. Como Lesser (2001: 10) constatou em seus estudos sobre os povos do Oriente Médio e asiáticos nos "onipresentes mundos brasileiros termos como "estrangeiro" e "brasileiro" podem ser sinônimos". Ainda mais que "para muitos brasileiros, as identidades múltiplas já eram comuns muitos antes de os aviões terem transformado as viagens internacionais em questões de horas, e não mais de semanas ou meses". A imigração no Brasil no passado já havia produzido amiúde essas identidades múltiplas que surgem no mundo contemporâneo. Este mundo em globalização que desloca e contesta as identidades monolíticas de uma cultura nacional, racial ou étnica, como Hall (2005: 87) definiu, "tem um efeito pluralizante sobre as identidades, produzindo uma variedade de possibilidades e novas posições de identificação, e tornando as identidades mais posicionais, mais políticas, mais plurais e diversas, menos fixas, unificadas ou trans-históricas”. O sistema de duplas nacionalidades institucionalizou esta condição pós-moderna.

A negociação da identidade nacional, e como ele percebeu, permanece caracteristicamente não-hifenizada, com toda a ambigüidade que daí decorre. Como Lesser (2001: 27) colocou, "os imigrantes e seus descendentes puderam abraçar sua "niponicidade" ou sua "libanicidade", tanto quanto sua 'brasilidade'". Ao invés de um hífen oculto, uma dupla consciência de si. Expressivo desta realidade é a afirmação de um palestino de segunda geração entrevistado por Espinola: "Eu me sinto brasileiro e palestino" (Espinola: 185). De maneira ainda mais intensa, a declaração do Adib Ahmad tratando dos grupos de resistência acusados de terrorismo (como o Hamas e o Hezbollah), se refere a duas lutas nacionais diferentes como sua, os símbolos de um lado servem para exemplificar e justiçar o do outro: 
Quem sabe é um grupo de resistência, nacionalista. Quem sabe (são) pessoas que amam a sua terra e resolveram dar a vida (por ela). Nós temos aqui o Tiradentes. Para os ocupantes do Brasil naquela época era terrorista. Tanto que ele foi massacrado, morto, esquartejado e jogado em tudo que é canto para dar exemplo para as outras pessoas não lutarem. Mas qual era o objetivo de Tiradentes? Era igualdade, fraternidade. O que ele queria? Ele sonhava com esse Brasil que hoje tem. Tanto que nós paramos por um dia, a nação brasileira toda para por um dia para que? Para homenagear um ser humano que na época para os ocupantes era terrorista. Muito depende. Quem tem que contar a nossa história somos nós, não o nosso inimigo. É obvio que os Estados Unidos e os judeus vão falar mal de nós.

Independente do quão anacrônica possa parecer tal comparação, ela revela uma identificação entre a resistência nacional palestina e a brasileira, como fenômenos análogos e vítimas do mesmo processo de demonização. Mas Adib os compara utilizando para ambos a primeira pessoa do plural, de modo que revela fazer parte de ambos. "Nós paramos", "a nação brasileira", seguido por "os Estados Unidos e os judeus vão falar mal de nós”, nesse caso, "nós", os palestinos. Entre as duas frases, diz-se que "quem tem que contar a nossa história somos nós, não o nosso inimigo", ou seja, a nossa história, a de Tiradentes por um lado, que seria considerado terrorista pelos "nossos inimigos", dos brasileiros, e dos grupos de resistência palestinos por outro, acusados pelos "nossos inimigos", dos palestinos, de terrorista.

A ambiguidade de ser brasileiro e palestino ao mesmo amplia os horizontes de identificação, e concilia o que pode ser visto como inconciliável. Como mesmo Espinola (2005: 227-228conclui em sua tese, "a comunidade árabe em seu diálogo intercultural, dentro do contexto local e nacional, com sua história da incorporação de imigrantes e da construção da nação brasileira, mantém a possibilidade de sentir-se palestino e brasileiro, sem o hífen". Esta pluralidade de identidades apresenta-se ao mesmo tempo como uma característica do Brasil, do mundo em globalização e de um período que não é mais o da padronização nacionalista dos regimes autoritários, como o Estado Novo (1937-1945) e a Ditadura Militar (1964-1985) no Brasil. Portanto, os imigrantes estudados são "palestinos de coração brasileiro".

Como demonstra Peralva, as relações de continuidade entre os grupos de migrantes e sua terra continuam mesmo durante a migração (Peralva, 2008: 18). As redes permitem sobrepor vários espaços sociais, mantendo-se relações em diversos níveis e lugares ao mesmo tempo. Isto acarreta mudanças significativas para manutenção da identidade cultural longe da terra de origem, pois é possível manter-se conectado a ela. Fenômeno já apontado por Dana Diminescu, o migrante conectado é também um migrante que não rompe os laços de origem e, portanto, mantém de alguma forma uma relação de proximidade com seu espaço de origem e 
outros espaços (Diminescu, 2008: 567). Esta ausência de uma dicotomia clara e forte entre os lugares causa uma série de superposições que nem sempre são lidadas da mesma forma. Segundo Castells (1999), Era Informacional apresenta uma dicotomia entre a Rede e o Ser, uma espécie de paradoxo ou alguma aversão subjetiva a globalização. No entanto, estar multilocalizado também pode significar uma múltipla identificação com os lugares e as culturas.

Apesar do papel significativo da identidade palestina para autodefinição e afirmação como grupo, existe, à primeira vista, uma aparente ambiguidade entre os imigrantes, revelada em suas falas e discursos. Num artigo escrito para o jornal Brasil de Fato sobre a iniciativa de construir uma escola técnica em sua vila natal, Othman define a sua própria comunidade como "os "palestinos na diáspora" - um grupo de brasileiros de origem Palestina -, dominados pela justiça, assumiram seu dever cívico perante a Pátria-mãe” (Brasil de Fato, 2009). Numa mesma frase, ele se diz brasileiro e palestino, sem que isso pareça contradição ou haja limites em sua plena inserção em qualquer uma delas. Percebe-se isso pelo uso da preposição "na" em "na diáspora", ao invés de "da diáspora", o que indicaria uma característica inerente ao invés de uma situação.

Em sua tese, Espinola conclui que "a comunidade árabe em seu diálogo intercultural, dentro do contexto local e nacional, com sua história da incorporação de imigrantes e da construção da nação brasileira, mantém a possibilidade de sentir-se palestino e brasileiro, sem o hífen" (Voigt, 2005: 228). A ambiguidade de ser brasileiro e palestino ao mesmo amplia os horizontes de identificação, e concilia o que pode ser visto como inconciliável. As identidades sobrepostas desses palestinos indicam um jogo constante de identidades e pertencimentos, que não anula a especificidades deste grupo entre palestinos e entre brasileiros, mas que evidencia as multiplicidades inerentes a todas as culturas e nações, num amplo campo de identificações. Também realçam a interdependência dos povos e culturas, que buscam no "outro" algo que possa melhor definir o "nós", neste constante atravessar de fronteiras entre os grupos culturais, sem se estabelecer necessariamente em um só lugar.

Entretanto, a identidade nacional brasileira é em muitos aspectos mais ampla e mais vaga que a palestina, devido às configurações históricas peculiares a cada país, bem com as dimensões tanto dos dois povos e suas respectivas terras. Os referenciais políticos e espaciais são mais amplos e mais variados, sem uma verdadeira força oposta ameaçadora que una os brasileiros na defesa de sua nação. De modo semelhante, a diversidade de regiões e etnias dentro do Brasil dificilmente poderia encontrar uma definição simples e fixa. "Numa terra que é multicultural, mas não-hifenizada, as negociações sobre a identidade nacional 
continuam em andamento" (Lesser, 2001: 300), ou seja, talvez este seja o próprio significado de identidade nacional no Brasil, a negociação particular de cada grupo e de cada indivíduo da nacionalidade ao invés de uma identidade hifenizada claramente delimitada. Stuart Hall verifica dois modelos gerais de identidades culturais na pós-modernidade, o primeiro, a tradição, é o reforço das velhas identidades como sendo inerentes e fechadas. Certamente, não é este modelo que constata a alteridade e a permeabilidade presentes nas identificações dos palestinos e de tantos outros imigrantes no Brasil:

Pois há uma outra possibilidade: a da tradução. Este conceito descreve aquelas formações de identidades que atravessam e intersectam as fronteiras naturais, compostas por pessoas que foram dispersadas para sempre de sua terra natal. Essas pessoas retêm fortes vínculos com seus lugares e suas tradições, mas sem a ilusão de um retorno ao passado. Elas são obrigadas a negociar com novas culturas em que vivem, sem simplesmente serem assimiladas por elas e sem perder completamente suas identidades. Elas carregam os traços das culturas, das tradições, das linguagens e das histórias das particulares pelas quais foram marcadas. A diferença é que elas não são e nunca serão unificadas no velho sentido, porque elas são, irrevogavelmente, o produto de várias histórias e culturas interconectadas, pertencem a uma e ao mesmo tempo, a várias "casas" (e não a uma "casa em particular"). (Hall, 2005: 88-89) 


\section{Considerações Finais}

Constatou-se que os palestinos em Santa Catarina assumem, além de sua própria, da árabe e da religiosa, a brasileira em diversos momentos de forma alterada. A dupla identidade que assumem é comum a outros grupos de imigrantes, o que indica uma característica própria da formação ou, talvez, da indefinição dessas identidades no Brasil. Isto pode muito bem estar relacionado com a aversão ao ritualismo do qual menciona Sérgio Buarque de Holanda (Holanda, 1995: 147) a respeito do brasileiro típico, aonde se rompe com as regras formais de relacionamento que buscam preservar a exclusividade, que poderia ser o caso de uma identidade hifenizada. Desta forma, o tratamento e relacionamento direto e pessoal elaboram uma identidade circunstancial, imiscuída na coletividade, uma definição vinda de fora e não do interior. Talvez seja este horror da interiorização que dificulta a formalização das etnias e da nacionalidade na sociedade brasileira, que contemplam uma acepção individual e específica de cada grupo.

A este enigma que é a nação brasileira se junta mais um grupo, que traz suas próprias contribuições e questionamentos. Atestando as palavras de Lesser, "a imigração foi de fato a construção da identidade nacional" (Lesser, 2001: 28), e estes imigrantes certamente ajudam um pouco a entender quem é este brasileiro. A dupla consciência, o "estrangeiro" e "brasileiro" como um sinônimo, de certa forma, não deixa de ser percebida em um relato de Adib Ahmad: "Como nós somos estrangeiros, a maioria do povo que hoje constitui o Brasil, ou alemães, ou poloneses, ou americanos, de todas as raças e de todas cores vem aqui para este Brasil e todas elas não se sentem dono da terra". Esta talvez seja a ironia da nãohifenização dos imigrantes, a assimilação e integração a sociedade brasileira, ao mesmo tempo em que se pode ser de fora, ser um estrangeiro como tantos outros.

$\mathrm{O}$ intricado processo de migratório palestino de sua terra natal ao Brasil até o momento só foi esboçado. Desde a primeira leva pioneira ainda na década de 1950 até as novas migrações passageiras, os palestinos marcaram sua presença por diversas cidades brasileiras. O estudo desse grupo serve como contribuição para compreensão das migrações contemporâneas, pois revela como o processo migratório transformou-se ao longo do tempo, adquirindo novas feições sem perder muitos dos elementos que lhe conferem peculiaridade.

Ao invés da Era Informacional fragmentar as identidades, como percebeu Castells (1999), ela tende a fortaleça-las, permitindo a manutenção da identificação através do tempo e espaço. Mas o caminho inexorável não é necessariamente o fundamentalismo, pois as 
identidades podem ser múltiplas e não-excludentes. O caso dos palestinos em Santa Catarina, por mais que existam contradições, exemplificam essa possibilidade do chamado "homem traduzido" para utilizar a expressão tomada de Salman Rushdie por Hall (2005: 88-89).

As redes sociais, os fluxos de informações e solidariedades são manifestações que não se limitam a este grupo, pois se inserem num novo fenômeno de relações sociais multilocalizadas. Diferente do que poderia se pensar, as identidades culturais de tipo étnico ou primordial não desaparecem no meio da multiplicidade de referenciais. Ao contrário, elas são frequentemente fortalecidas pela continuidade dos laços sociais mantidos através do espaço de fluxos. Não significa necessariamente uma oposição entre a Rede e o Ser, pois esse fortalecimento de uma identidade particular não exclui outras posições identitárias. $\mathrm{O}$ apego aos costumes e as tradições entre os palestinos em Santa Catarina, não os fez menos brasileiros em sua visão, pois ao mesmo tempo puderam permanecer brasileiros a sua própria maneira. 


\section{Entrevistas}

Abdel Ibrahim Muhammad. Entrevista realizada em 27/07/2010 em Tubarão - SC

Abid al Nasser Tawfik Abid al Latif Abu Hussein Al Basha. Entrevista realizada em 23/08/2010 em Florianópolis - SC

Adib Omar Mahmoud Ahmad. M. Entrevista realizada em 06/12/2007.

Mahmoud Hassan Daud Hussein. Entrevista realizada em 06/12/2007 em Florinópolis - SC

Mohammad Mahasan. Entrevista realizada em 25/08/2010 em Lages - SC

Abdul Mohammad Oda. Entrevista realizada em 27/08/2010 em Criciúma - SC

Munif Mahmud Salim Omar. Entrevista realizada em 31/07/2010 em Criciúma - SC

Kader Othman. Entrevista realizada em 18/10/2007 em Florianópolis - SC 


\section{Bibliografia}

AHMED, Akbar S \& DONAN, Hastings (ed.) Islam, Globalization and Postmodernity. London: Routledge, 1994.

BHABHA, Homi K. O Local da Cultura. Belo Horizonte: Editora UFMG, 1998.

BALAKRISHNAN, Gopal (org.). Um mapa da questão nacional. Rio de Janeiro: Contraponto, 2000.

CAPELLO, Ernesto. Carrying the past: the Syrio-Lebanese Emigration to Brazil. In: AlMashriq, vol. 3, no. 9, 2004, PP. 76-86

CARDOSO, Michele Gonçalves. Allah na cidade das etnias. In: OPSIS - Curso de História. Dossiê Cultura e Identidades. Universidade Federal de Goiás - Campus Catalão. Catalão GO, v. 8, nº 10, jan-jun. 2008. P.161-177

CASTELLS, Manuel. A Sociedade em Rede. São Paulo, Paz e Terra, 1999. O poder da identidade. São Paulo: Paz e Terra, 1999

DIMINESCU, Dana. The connected migrant: an epistemological manifesto. Social Science Information Vol. $47-\mathrm{n}^{\circ} 4$

DOWTY, Alan. Emigration and Expulsion in the Third World. In: Third World Quarterly, Vol. 8, No. 1 (Jan., 1986), pp. 151-176P

EDER, Klaus. Identidades coletivas e mobilização das identidades. In: RBCS, Vol. 18, № 53, outubro/2003.

ESPINOLA, Claudia Voigt. Agruras e delícias do trabalho de campo na Comunidade Muçulmana de Florianópolis. IN: FERREIRA, Francirosy Campos B. (org) Olhares femininos sobre o Islã: etnografias, metodologias, imagens. São Paulo: Editora HUCITEC, 2010

O véu que (des)cobre: etnografia da comunidade árabe muçulmana em Florianópolis. Tese de Doutorado. Universidade Federal de Santa Catarina. Programa de Pós-Graduação em Antropologia social, 2005.

FARAH, Paulo Daniel. Geografia da ausência: o espaço na literatura palestina (da terra natal ao Brasil). Tese de Doutorado. Universidade de São Paulo. 2004.

FARSOUN, Samih K. Palestine and the Palestinians. Boulder: Westview Press, 1997. FAWAZ, Leila. The City and the Mountain: Beirut's Political Radius in the Nineteenth Century as Revealed in the Crisis of 1860 International Journal of Middle East Studies, Vol. 16, No. 4 (Nov., 1984), pp. 489-495 
FURTADO, Celso. Formação econômica do Brasil. São Paulo: Companhia das Letras, 2007.

GATTAZ, André. Do Líbano ao Brasil: história oral de imigrantes. São Paulo: Gandalf, 2005.

HAMID, Sônia Cristina. Entre a Guerra e o Gênero: Memória e Identidade de Mulheres Palestinas em Brasília. Dissertação de Mestrado. Universidade de Brasília. 2007.

HALL, Stuart. A identidade cultural na pós-modernidade. Rio de Janeiro: DP\&A, 2005. Da Diáspora: Identidades e Mediações Culturais. Belo Horizonte: Editora UFMG; Brasília: Representação da Unesco no Brasil, 2003.

HILTERMANN, Joost R. Israel's Deportation Policy in the Occupied West Bank and Gaza. Al-Haq, 1986.

HOLANDA, Sérgio Buarque. Raízes do Brasil. São Paulo: Companhia das Letras, 1995. HOURANI, Albert. The emergence of the Modern Middle East. Berkeley and Los Angeles: University of California Press, 1981.

. Uma História dos povos Árabes. São Paulo: Cia das Letras, 2006.

ISSAWI, Charles. British Trade and the Rise of Beirut, 1830-1860. International Journal of Middle East Studies, Vol. 8, No. 1 (Jan., 1977), pp. 91-101

KARAM, John Tofik. Another Arabesque: Syrian-Lebanese Ethnicity in Neoliberal Brazil. Philadelphia: Temple University Press, 2007.

KARPAT, Kemal H. The Ottoman Emigration to America, 1860-1914. International Journal of Middle East Studies, Vol. 17, No. 2 (May, 1985), pp. 175-209

KHALIDI, Rashid. Palestinian Identity: the construction of modern national consciousness. New York: Columbia University Press, 1997.

KIMMERLING, Baruch \& MIGDAL, Joel S. Palestinians: The making of a people.

Cambride: Harvard University Press, 1994.

KNOWLTON, Clark S. Sírios e Libaneses: Mobilidade social e espacial. Anhembi. 1961 JARDIM, Denise. "As mulheres voam com seus maridos": a experiência da diáspora palestina e as relações de gênero. In: Horizontes Antropológicos, Porto Alegre, ano 15, n. 31, p. 189 217, jan./jun. 2009

Famílias palestinas no extremo Sul do Brasil e na diáspora: experiências identitárias aduaneiras. Cadernos-pagu nº 29, 2007.

. Palestinos no extremo sul do Brasil: identidade étnica e os

mecanismos sociais da produção da etnicidade. Chuí - RS. Tese de Doutorado. 
Universidade Federal do Rio de Janeiro. Programa de Pós-Graduação em Antropologia Social, 2000. Os imigrantes palestinos na América Latina. Estudos Avançados v.20 n

57, 2006.

LAQUER, Walter \& RUBIN, Barry (ed.). The Israel-Arab Reader: A Documentary History of Middle East Conflict. London: Penguin Books, 2001.

LESSER, Jeffrey. A negociação da identidade nacional: imigrantes, minorias e a luta pela etnicidade no Brasil. São Paulo: Editora da UNESP, 2001. ( $(\mathrm{Re})$ Creating Ethnicity: Middle Eastern Immigration to Brazil. In: The Americas, Vol. 53, No. 1 (Jul., 1996), pp. 45-65 How the Jews Became Japanese and Other Stories of Nation and

Ethnicity. Jewish History, Vol. 18, No. 1, Gender, Ethnicity, and Politics: Latin American Jewry Revisited (2004), pp. 7-17

LEWIS, Bernard. O Oriente Médio: do advento do cristianismo aos dias de hoje. Rio de Janeiro: Joger Zahar, 1996.

MEIHY, José Carlos Sebe Bom. Manual de História Oral. São Paulo: Loyola, 2005. MIGUEL, Salim. Nur na Escuridão. Rio de Janeiro: Topbooks, 2004.

OSMAN, Samira Abdel. Perspectivas identitárias na comunidade líbano-brasileira. Anais do XIX Encontro Regional de História: Poder, Violência e Exclusão. ANPUH/SP-USP. São Paulo, 08 a 12 de setembro de 2008.

PAPPE, Ilan. História da Palestina Moderna: Uma terra, dois povos. Lisboa: Editorial Caminho, 2007.

Ethnic Cleansing of Palestine. Oxford: Oneworld, 2006.

PERALVA, Angelina. Globalização, migrações transnacionais e identidades nacionais. In: iFHC/CIEPLAN, 2008.

POLLAK, Michael. Memória e Identidade Social. IN: Estudos Históricos, Rio de Janeiro, vol. 5, n. 10,1992 , p. $200-212$

REYNOLDS, John. Where Villages Stood: Israel's continuing violations of International Law in Occupied Latroun, 1967-2007. Ramallah: Al-Haq. December, 2007.

ROGAN, Eugene L. Sectarianism and Social Conflict in Damascus: The 1860 Events Reconsidered. Arabica, T. 51, Fasc. 4 (Oct., 2004), pp. 493-511

SAFADY, Jamil. O café e o mascate. s. n. t. 
SAID, Edward W. Orientalismo: O Oriente como invenção do Ocidente. São Paulo: Cia das Letras, 2007.

Reflexões sobre exílio e outros ensaios. São Paulo: Cia das Letras, 2003. The Question of Palestine. New York; Vintage Books, 1992.

SAFADY, Jamil. Panorama da imigração árabe. São Paulo: Editora comercial Safady. s.d. SAFADY, Wadih. Cenas e cenários dos caminhos da minha vida. Belo Horizonte:

Estabelecimentos gráficos Santa Maria, 1966

SAYAD, Abdelmalek. A imigração. São Paulo: Editora da Universidade de São Paulo, 1998

SCHILLER, Nina Glick, BASCH, Linda, BLAN, Cristina Szanton. From Immigrant to

Transmigrant: Theorizing Transnational Migration. IN: Anthropological Quarterly, Vol. 68, No. 1 (Jan., 1995), pp. 48-63

SMITH, Pamela Ann. Palestinian Diaspora, 1948-1985. In: Journal of Palestine Studies, VOL. 15, No 3, (SPRING, 1986), pp. 90-108

TANNOUS, Afif I. Group Behavior in the Village Community of Lebanon. The American Journal of Sociology, Vol. 48, No. 2 (Sep., 1942), pp. 231-239

TRUZZI, Oswaldo. De mascates a doutores: sírios e libaneses em São Paulo. São Paulo: Editora Sumaré, 1992.

TRUZZI, Oswaldo. Patrícios: sírios e libaneses em São Paulo. São Paulo: Editora UNESP, 2009.

WEISS, Anita M. Challenges for Muslim women in a postmodern world. In: AHMED, Akbar S \& DONAN, Hastings (ed.) Islam, Globalization and Postmodernity. London: Routledge, 1994. P. 127-140 


\section{Anexo: Mapa da imigração palestina em Santa Catarina}

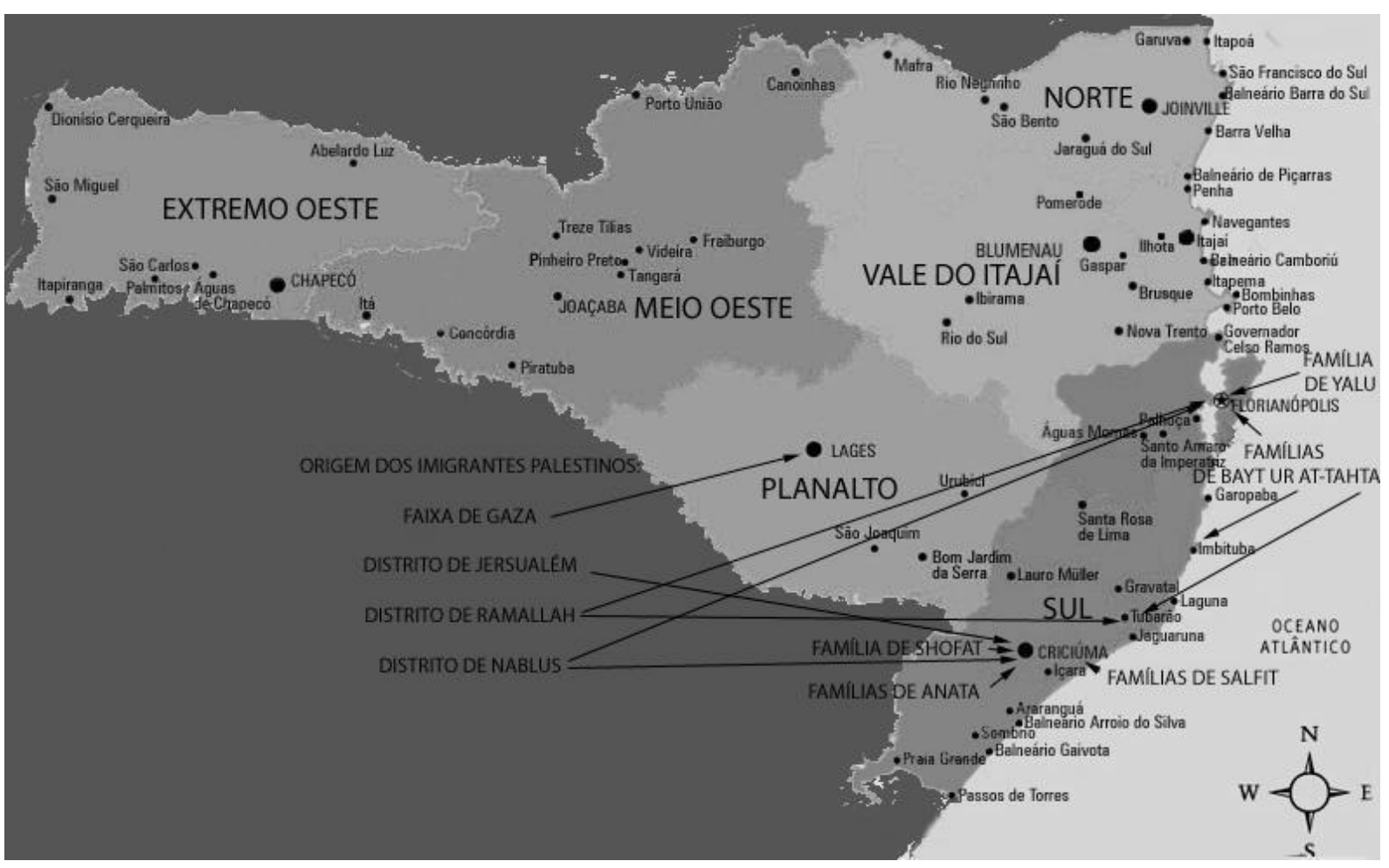

